\title{
REPRESENTATIVE INSTITUTIONS IN WESTERN SAMOA during the Mandate 1919 - 1946
}

\author{
J. R. MARTIN
}

Submitted in partial fulfilment of the requirements for the Degree of Master of Arts in Political Science at Victoria University of Wellington, New Zealand, 1959. 


\section{TABLE OF CONTENTS}

Preface

Chapter I - The Country and the People I

Chapter II - The Historical Background 20

Chapter III - The Fono of Faipule 81

Chapter IV - The Legislative Council 101

Chapter V - The Reconstituted Fono of Faipule 125

Chapter VI - The Reconstituted Legislative Council $\quad 139$

Chapter VII - District and Village Government

Chapter VIII - Conclusion 155

$\begin{array}{ll}\text { Bibliography } & 171\end{array}$ 
This study began as a description of the government of Western Samoa as a whole during the Mandate period 1919-1946. It soon became apparent that within the limits imposed by the time and space available it would not be possible to give an adequate treatment of such a wide subject. The scope was then reduced to a study of representative institutions during the period; the thesis is thus concerned with a well defined aspect of colonial administration rather than to provide a well rounded study in comparative political institutions. (To put the study in its correct perspective it was necessary also to include a brief chapter on District and Village Government and quite lengthy descriptive and historical chapters.)

An additional reason for reducing the scope of the work was the wealth of untouched primary material available in the records of the Department of Island Territories, which were made freely available by the Secretary (Mr. J.M. McEwen). The scarcity of documentation available on the controversial history of New Zealand's Mandate - a matter of considerable concern in view of the Territory's imminent independence - made it seem worthwhile to collate as fully as possible material from this primary source. Although this may perhaps have been achieved at the cost of developing an original narrative, the exercise of 
compilation will have been of some value if it provides a starting point for more analytical studies.

The material presented in this thesis lends itself to interpretation from two equally interesting viewpoints: first, it illustrates certain aspects of New Zealand's Mandatory policy, which must figure prominently in a study of the causes of the movement known as the Mau; secondly, the institutions of the modern Parliamentary government, which exists in Samoa today, are in a direct line of development from the Fono of Faipule and Legislative Council described in the following pages. In the final chapter an attempt is made to look at Samoan participation in the government of the Territory from both these viewpoints.

The secondary sources which have been consulted are listed in the bibliography; mention should be made here, however, of the debt owed to the various writings of J.W. Davidson on problems of government in Western Samoa, and to a lesser extent of F.M. Keesing on Samoan social structure and custom. I have also been fortunate in having had the opportunity of discussing the subject matter of this work with the High Commissioner of Western Samoa (Mr. G.R. Powles, C.M.G.); Professor Davidson; Professor C.C. Aikman of Victoria University (Adviser to the New Zealand Government on Samoan constitutional matters); and Mr. C.G.R. McKay (former Secretary of Native Affairs 
and Secretary of Island Territories). All have helped my understanding of the events and institutions described in. this work although, needless to say, the final product is entirely my own responsibility. 


\section{THE COUNTRY AND THE PEOPLE}

\section{Geographical}

The Territory of Western Samoa lies between latitudes $13^{\circ}$ and $15^{\circ}$ South and longitudes $171^{\circ}$ and $173^{\circ}$ West. It comprises the two large islands of Savai'i and Upolu and the much smaller islands of Manono and Apolima. Total land area is about 1,090 square miles $(2,823 \mathrm{sq}$. kilos) of which 660 square miles ( $1,709 \mathrm{sq}$. kilos) are in Savai'i and about 430 square miles ( $1,116 \mathrm{sq}$. kilos) in Upolu. The islands are formed mainly of volcanic rocks, with coral reefs fringing much of the coastline. Rugged mountain ranges form the core of both main islands and rise to 3,608 feet $(1,100$ metres $)$ in Upolu and 6,094 feet ( 1,857 metres) in Savai'i. Samoa is an area of dormant volcanoes, large areas of previously cultivated land in Savai'i having been covered by lava between 1905 and 1911, the most recent period of activity of the volcano, Matavanu.

The climate of Samoa is tropical, with two distinct seasons, wet and dry. Temperature ranges are not considerable, either daily or seasonal, the mean daily temperature remaining reasonably constant at about $80^{\circ} \mathrm{F}$. Although Samoa lies outside the normal track of hurricanes, occasional severe storms are experienced.

Much of the land, particularly on the larger island of Savai'i, is uncultivated although large areas comprise lava and rocks. At present over two-thirds of the population 
live on Upolu, where cultivation is much more intensive. Coconut palms are normally planted on the lower coastal fringe and cocoa trees in smaller blocks on the higher levels. As much of the produce of Samoan land is for purely domestic consumption, shifting cultivation is still extensively practised. Rarely are the crops planted on the permanent field system, and normally a semi-formal layout is found only in banana or taro patches. As the land around the village precincts is in many cases depleted, this area is mainly in poor coconuts and pig raising, but further up the slopes - below the bush level - coconuts give way to cocoa and bananas.

The Samoa Act 1921 distinguished three types of land titles: "Crown", originally "ex-enemy" property, both public and private; "European", being land owned by non-German settlers; and "Samoan" land which was vested in the Crown as trustee. Samoan land may not, in general, be permanently alienated except to the Crown and is held in accord with Samoan usage and custom. (See below.) Approximately 80\% of the land area of the Territory is held by Samoans. The greater part of the remaining area belongs to the Western Samoa Trust Estates Corporation, until 1957 the New Zealand Reparation Estates. These extensive cocoa, copra and livestock plantations were taken over by the New Zealand 
Government as war reparations after World War I and, under different systems of management, have made a tremendous contribution to the Samoan economy.

\section{The Economy}

Trends of production of the main export crops copra, cocoa, bananas and during the 1930's, some rubber are discussed by V.D. Stace in his "Economic Survey" of Western Samoa. 1 His finding is that -

"... after World War I the overall efficiency of export production per head increased slowly but steadily until civil disorders from 1926 and the difficulties of the financial depression years of the early 1930's slowed down and reversed the trend. After a shortlived recovery in 1935-39, the impact of World War II on Western Samoa's economy directed productive effort away from export industries to such an extent that the per capita volume of exports in these years was some $22 \%$ less than that recorded during World War I. Since the second World War the value of trade has soared upward, but the volume of production per head as indicated by export trade has increased merely enough to restore the production standards obtaining 50 years ago, and not enough by some $18 \%$, to reach the position ruling in the 1920's." (p.10)

of the individual crops, the annual production of copra - produced to the extent of $80 \%$ by Samoan growers increased from an average of 9,700 tons in the period 1910-1914, to 13,500 tons 15 years' later, but declined to

1 Western Samoa - An Economic Survey, Noumea, 1956, p.10. 
11,000 in the five year period 1930-1934. An improvement in international market prices caused an upsurge of production in the immediate pre-war years. Stace points out that "the very absence of alternative sources of income for the plantation owners and village producers concerned ensures that a remarkably high level of production is maintained in spite of extremely unprofitable prices". 1 Western Samoa provides an unusually favourable environment for cocoa, but exports remained only between 700 and 900 tons annually from 1914 to 1936, when rapid expansion of the industry occurred. The production of cocoa was, during most of the period covered by this study, mainly an activity of European plantations, hardly any cocoa being produced by Samoans even as late as 1927. However, the Administration took steps to develop Samoan interest, and by 1937 it was estimated that 22\% of the Territory's production was from Samoan village plantations. Bananas have been shipped in quantity to New Zealand since 1928, when the New Zealand Government and the local Administration actively sponsored the trade. The NZGMV "Maui Pomare" initially provided the transport, but the provision of adequate shipping space was always a problem until the late 1950's. 
3. Population

The great majority of the people of Western Samoa are indigenous Polynesians of nearly pure Samoan ancestry. Since 1926, an increasingly successful public health programme, together with steady improvement in the natural resistance of the Samoan people to recently introduced diseases, has allowed the population to increase at a rate thought to be one of the most rapid in the world. The following census enumerations illustrate this trend -

$31.12 .1906 \quad 37,320$

$31.12 .1911 \quad 38,084$

$31.12 .1921 \quad 37,157$

1. $1.1925 \quad 40,229$

(1918 influenza epidemic)

4.11 .1936

55,946

25. $9.194568,197$

25. $9.195184,909$

25. $9.1956 \quad 97,327$

All residents of Western Samoa possess either "European" or "Samoan" status. A "Samoan" is defined in the Samoa Act 1921 as, "a person belonging to one or more of the Polynesian races". The definition includes as Samoan, without qualification, all who are of more than threequarter Polynesian blood. Broadly speaking, all others are "Europeans", in domestic status, even though their nonSamoan blood may be, for example, Asiatic. Provision exists for persons of half-Samoan blood or more to petition the High Court to declare them "Samoans". Of the 5,500 or so persons of "European" status only a few hundred (mostly expatriate public servants) are pure Europeans. 
4. Samoan Social Organisation

"Native Samoa today /I9347 in political and ceremonial affairs has the dual characteristics of great conservatism and of extraordinary

disintegration and uncertainty; as such it is by no means easy to describe." 1

The only stable unit of the traditional Samoan social structure was the village ( $\left.\underline{n} u^{\prime} u\right)$ which catered for the day to day needs of Iife and was practically autonomous in all local matters. The German scholar Kraemer, in approximately 1900, recorded the total number of villages in Western Samoa as about 80; when Keesing wrote, the number recognised by the Administration was about 170; the latest Annual Report speaks of "some 400 foreshore villages", averaging between 200 and 350 inhabitants. The increase is explained by the tendency of sub-units of a village to "throw off for practical purposes the traditional bonds that limit their ceremonial autonomy". 2

Beyond the village unit the traditional organisation was concerned with ceremonial politics rather than with effective government. The autonomy and isolation of the villages is an important factor in the traditional social structure and helps to explain the difficulty which alien Administrations have experienced in establishing real

1 Keesing F.M., Modern Samoa - Its Government and Changing Life, London, 1934, p.141. 
contact with the Samoan communities; although the islands are comparatively small in area, until recently the difficulties of communication through the rugged and heavily wooded terrain have meant that "the social space between the outer villages and Apia is greater than the actual distances may suggest". ${ }^{1}$ Each village had its place in sub-district and district combinations (itu). Originally these divisions were based on kinship ties but more recently the need for common defence determined their boundaries. For the purposes of modern political discussions, Upolu is composed of the three districts, Aana, Tuamasaga and Atua, each with a number of sub-districts; Savaili is composed of six districts, Fa'asaleleaga, Gaga'emauga, Gagaifomauga, Satupa'itea, Palauli, Vaisigano. (These districts are not geographical blocks but in some cases are composed of two areas, separated by a second political district.) Within the large political units the villages had their own traditional functions: one, for example, would be the capital, while another would have particular tasks in time of war. Similarly with the sub-districts within the largest unit. This complex interplay of villages and districts was typified by the organisation of pule and Tumua; certain villages (one in each of the nine political districts) were

1 Stanner W.H., The South Seas in Transition, Sydney 1953, p.283 
of such traditional significance that they were entitled to speak, normally after the proper $\underline{\mathrm{fa}^{\prime} \mathrm{a}} \underline{\text { Samoa }}^{1}$ discussion for the district. It was the decision of a majority of these politically important villages that decided which of the contending parties - usually focussed on one of great families or their leaders - was for the time being the malo, or dominant group. ("Malo" remains as the Samoan word for "government".)

In general, Aana and Atua in Upolu supported the great Tupua family in opposition to Tuamasaga, all of Savai'i, and Manono who combined to support the Malietoa faction. The relationship between the villages and the larger units of Samoan society has been well expressed by J.W. Davidson ${ }^{2}$ -

"Fundamentally" says Dr. Davidson "/the difficulties of governing Samoa 7 spring from the immaturity of indigenous political institutions above the village level. Within the village, Samoan organisation has been, and largely remains, highly effective. The village still functions as a unit, socially and economically; and the edicts of the village fono are still accepted as the rightful means of maintaining law and order. But beyond the village the Samoans had no stable system of administration, only complex networks of alliances formed on grounds of tradition, consanguinity or policy. To find a comparison within our ordinary knowledge or experience, we must look to the sphere of international relations, rather than to that of

1 Fa'a Samoa - "the Samoan way of doing things". It is a term of great flexibility used to describe the usages of Samoan custom.

2 The Government of Western Samoa - Survey, Wellington, Department of External Affairs, 20 June 1947, (Cyclostyled), p.2. 
the internal government of states. The nightmare history of the Balance of Power in Europe has its counterpart in the tangled story of Samoan

dynastic alliances. The holders of the higher

Samoan titles, or rather the orators behind them (the local Richelieus and Metternichs), were concerned in their mutual relations with matters of power and status and common interest, not with those of law and order and continuous administration."

At all levels of political life the institution of "government" was the ceremonial council ( $\underline{\text { fono }}$ ); village councils, district councils, those of allied districts (especially of the malo party) and, on occasions, a fono of all Samoa. The village council was, and is, an effective working body meeting usually once a week; it is here that the day to day affairs of the village community are decided by the matai of the village (known in their collective capacity as the ali'i and faipule).

Politics in Samoa were and are the concern only of the matai or men of title. The title is derived from the aiga or extended family group. Grattan describes the aiga in this manner -

"Such a family is not merely a biological group, as Europeans understand the term, consisting of parents and children, but a wider family group of blood and marriage and even adopted connections who all acknowledge one person as the matai or head of that particular family. Such a matai is a titled person, either a chief (ali'i) or an orator (tulafale or failauga) whose particular duty is the leadership and care of the family under his control, and who is entitled to the services and co-operation of all 
members of his family in return for his leadership. All members of such a family group need not necessarily live under the same roof or even in the same village but will, when occasion requires it, assemble, generally at the residence of the matai, to discuss family affairs or any happenings affecting the interests of the family, or to discharge the duties associated with deaths or weddings. Such an assembly to discuss family affairs is not merely a duty on the part of members of the family but is a right which is jealously guarded ... It is the duty of the matai to take care of the family land and to apportion it for the use of members of the family in return for services rendered to him as head of the family."I

Succession to a matai title is not necessarily hereditary; all within the wide family group are eligible. The whole family meet to choose one whose conduct has commended him to them. Important considerations are questions of blood connection and descent, service to the family and personal qualities. (In practice, custom concedes that a surviving brother, if possessed of suitable qualities, has a good claim.)

As well as his position in the aiga, the matal has his role and status in the wider political groupings. In some cases the matai name may have only limited local significance but the hierarchy extends to the high chiefs whose titles have influence extending over whole districts

1 Grattan, F.J.H., An Introduction to Samoan Custom, Apia, 1948, p.11. 
and among widespread relationship groups "and who, because of the directness of their descent from the gods, to whom the great families traced their origin, were regarded as supernatural beings."I

Any real understanding of Samoan politics must begin with the inter-relationship of matai titles; that is why the present study cannot claim to give more than the framework of the institutions discussed. The life behind them was the interplay of fa'a Samoa roles and traditional rivalries. One important point which bears repetition is that government was never a highly developed art amongst the Samoans; above the village level politics have traditionally been devoted to questions of ceremony, status and prestige. "Who gets what, when, how?" is very much an alien introduction.

\section{The Administration}

The constitutional basis of the system of Government in the Mandate Territory was the Samoa Act 1921 and its amendments. The principal Act vested the executive government of the Territory in "His Majesty the King in same manner as if the Territory were part of His Majesty's

1 Keesing, op. cit., p.53. 
Dominions". It provided that an Administrator should be appointed by the Governor-General of New Zealand, to be charged with the administration of the Territory subject to the control of the Minister of External Affairs. Just as in British colonial territories the Governor was the central institution, so in Western Samoa the Administrator dominated every activity of government -

"All power and responsibility are concentrated in him; every act of the government is done in his name; he is the sole channel of communication with the imperial government ... The governor is also, as the representative of the imperial government, the supreme guardian of native interests ... At the same time the governor is the ceremonial head of the colony and the leader of society .... All this surrounds him with an aura of dignity and unapproachability that is an important factor in the political life of the colony." I

The history of the Administratorship of Western Samoa went through several phases. Col. Tate, the first civil Administrator, had the task of establishing an Administration in an atmosphere at first of doubt as to the future of the islands and all the time of uncertainty as to New Zealand policy (he also complained of the undermining of his authority by too frequent visits of Parliamentary and Ministerial parties). ${ }^{2}$

1 Wight M., The Development of the Legislative Council 1606-1945, London, 1946, pp.145, 146, 147.

2 See, for example, Administrator to Minister of External Affairs, 10 April 1922, File I.T.2/11 (Policy Samoan Affairs). 
The next Administrator, Sir George Richardson (1923-1928) embarked with enthusiasm on a programme of well intentioned reforms aimed at developing Western Samoa in the interests of the Samoans notwithstanding their "lack of vision". Following the unfortunate end to Richardson's administration in an atmosphere dominated by the Mau unrest and unfavourable world publicity, there was a reaction in favour of control from Wellington. In place of the freedom which Sir Francis Bell, as Minister, had allowed Richardson, his successors were subject to close supervision from the Department of External Affairs in Wellington; even legislation on Samoan internal affairs was found increasingly in New Zealand Orders in Council rather than in Ordinances of the Legislative Council. After the two fairly undistinguished administrations of Sir stephen Allen (1928-31) and Sir Herbert Hart (1931-35), when the first consideration was the restoration of peace and order, the long regime of A.C. Turnbull (later Sir Alfred) began in 1935. Of this period, J.W. Davidson ${ }^{1}$ commented in 1947 "... fa'a Samoa influences have been allowed to undermine the position of the Administrator himself. Before Sir Alfred Turnbull's retirement, his office had become - in the words of a Catholic priest who was his personal friend - 'despised and ignored'." 
Thus the reaction to Richardson's progressive administration was complete: Turnbull was subject to control in almost all matters from Wellington although certain pressing questions (such as local government) went by default; his authority was whittled away, as in Tate's administration, by the existence of direct lines of communication between Samoa and Wellington, particularly between the leaders of the Mau (including Nelson) and Langstone, the leader of the 1936 Goodwill Delegation. Col. Voelcker, who succeeded Turnbull in 1945, began to reassert the importance of the Administrator's position but found the initial good impression made by his vigour weakened by the necessity to refer all important matters for decision by a Prime Minister already over-burdened with responsibilities. Not until "self-government" became a real objective of New Zealand policy did Wellington begin to withdraw from the details of Samoan administration. The Administrator in his executive government was assisted by a number of Departments which, after several re-organisations, were at the end of the Mandate period: Government House; Education; Health; Justice, with which was associated Labour and Public Trust; Lands and Survey; Native Affairs; Police and Prisons; Postal and Radio; Public Works; Secretariat; Treasury; Customs, Produce 
inspection etc. (In the 1920's the Crown Estates later the Reparation Estates and now the Western Samoa Trust Estates Corporation - was virtually a department of the Administration (the board of management being headed by the Administrator); from 1931 on, they were controlled by a General Manager responsible to the Minister in Wellington.) One Department notable for its absence was the Agriculture Department, which was a casualty of the depression campaign for economy. J.W. Davidson (as Trusteeship officer) described the departmental organisation of the Mandate's administration thus -

"With an administration organised on such lines, there was much less need for - in fact there would, perhaps, have been little appropriateness in - a highly co-ordinated departmental structure. The Administrator was not himself a policy maker, except in a very minor way - a fact which Sir Alfred Turnbull openly and unashamedly proclaimed. Each branch of the Administration looked after its own affairs. The Treasury cared for the revenue, but without being expected to concern itself with the broader questions of economic policy ... The Department of Native Affairs remained 'the Government' to the people of the outer districts (so far as the people were made conscious of the Government at all). The Secretariat looked after odds and ends and provided an office for the Administrator,. Treasury, Native Affairs and Secretariat had little knowledge of what went on in either of the two offices. The Medical, Education and Public Works Departments saw to their own business and had little official contact with any other branches of Government." I

1 Trusteeship Officer to High Commissioner, 9 December 1949, File I.T.1/8/15, (Executive Council, Western Samoa: General.) 
The Departments were staffed by members of the Samoan Public Service created by the Samoa Act 1921. The Service was at first under the control of the Minister of External Affairs, who delegated to the Administrator the power of making appointments and fixing salaries. In 1931, however, in line with the policy of retaining control of Samoan affairs in Wellington, the Samoan Public Service was placed directly under the control of the New Zealand Public Service Commission. This arrangement continued until 1950, when, in accordance with the provisions of the Samoa Amendment Act 1949, a separate Western Samoan Public service, under the control of a Public service Commissioner, was established. Most appointments to the Samoan Public Service - throughout the Mandate period, all senior appointments - were made on secondment for a specified term, usually of three years from New Zealand. In 1947, at the end of the period, there were 71 positions held by full European officers, 102 held by local born Europeans of part Samoan ancestry, and 524 of full Samoans. (The great majority employed in the Health, Education, Police and Prison Departments.) $)^{1}$

1 Department of External Affairs, Western Samoa Report to the Trusteeship Council by United Nations Mission to Western Samoa, Wellington, 1947, pp.73, 74 . 
The public finance of the Territory was managed in accordance with certain provisions of the Samoa Act 1921 and the Samoan Treasury Regulations. Subject to these Regulations and to the control of the Minister of External Affairs, all moneys in the Samoan Treasury could be expended by the Administrator for such public purposes as he thought fit. Detailed annual estimates were forwarded by the Administrator for the approval of the Minister, after consideration by the Legislative Council and, in later years, by the Finance Committee.

In most years the annual public revenues of Western Samoa, exclusive of subsidies, ranged between $£ 105,000$ and $£ 140,000$ (although in the extreme depression year of $1934 / 35$ they fell as low as $£ 78,000$ ). In the ten years between 1921 and 1931, New Zealand contributed annual subsidies averaging about $£ 24,400$ for health and education services; these subsidies were later recovered from the accumulated profits of the New Zealand Reparation Estates. Ordinary public revenue was, in the latter years of the Mandate, derived almost wholly from indirect sources such as import and export duties and port operation. During Richardson's administration heavy direct taxation was imposed - with the consent of the Fono of Faipule - on all adult male Samoans. Under the influence of the "Mau organisation" 
the people refused to pay these or any other taxes, and in 1936 the Government revoked the tax law and cancelled uncollected amounts. To finance development, mainly in public works, the New Zealand Government made loans to the Administration totalling $£ 204,200$ in the early 1920's; these loans were finally repaid during the wartime prosperity.

The criminal code of Western Samoa was laid down in the Samoa Act 1921, which applied to the Territory the law of England as existing on 14 June 1840, with certain modifications. New Zealand statute law was inapplicable to the Territory, except as specifically provided. The Samoa Act also established a High Court of Western Samoa, to consist of a Chief Judge and "such other Judges and Commissioners as the Minister of External Affairs may think necessary". All appointments were at pleasure. From 1937, in accordance with an undertaking given by the Goodwill Delegation, Samoan Associate Judges sat with the Chief Judge during the hearing of cases involving Samoans. The Associate Judges also participated in the work of the Land and Titles Court (until 1937 "the Land and Titles Commission"), a separate Court of exclusive and final jurisdiction in matters relating to the control over Samoan land and of succession to matai titles. The Court was presided over by the Chief Judge. Until 1927 about fourteen 
Fa'amasino, or Samoan District Judge, were appointed with limited jurisdiction. The positions lapsed during the Mau unrest but were re-established in 1938, after representations from the Fono of Faipule. The Fa'amasino were appointed by the Administrator on the nomination of the Districts concerned.

One final institution requires mention. This is the position of Fautua, roughly interpreted as "Adviser to the Administrator". Established by the Germans to give recognition to the contenders for the former Samoan kingship, the position allowed the representatives of the highest chiefly families to be associated with the Administration. Until the creation of the Council of State by the Samoa Amendment Act 1947, the position was largely of ceremonial importance. For most of the Mandate period successive Administrators did not regard the advice of the Fautua as being of particular value, and consulted them infrequently. Until his death in 1939, Malietoa Tanumafili, O.B.E., the last Samoan "King" served as one Fautua; the other royal line "Tupua", was at various times represented by its three branches - Tuimalealiffano, Tamasese and Mata'afa. Not until the appointment of Tupua Tamasese (the President of the Mau) in 1937, on the death of Tuimalealiffano, did the position begin to assume the importance which it has gained under Trusteeship. 


\section{THE HISTORICAL BACKGROUND}

Before 1900

Between 1830, the year of the first arrival in the Group of the missionary, John Williams, and New Zealand's military occupation in August 1914, Western Samoa experienced a series of "interventions" by the commercial and diplomatic agents of a number of Western powers. By 1850, Germany, England and the United States had consular agents in Apia; by the 1880's, German economic interests centred in Samoa had spread through the South West Pacific; and by 1889 all three great powers had treaty relationships with the Samoan "king" which gave them coaling stations and "most favoured nation" rights in the Group. The confusion of the Samoan situation at this time was well illustrated by the presence of warships of three nations three German, three United States, and one British - in Apia harbour on 15 March 1889, the day of the famous hurricane in which the British "Calliope" alone steamed to safety, reputedly on Westport, New Zealand, coal. Each of the European powers involved supported a claimant to a Samoan "kingship" - a concept quite alien to Samoan social organisation; each was aware that no Samoan government could preserve good order in the island without European support; yet none was prepared to relinquish its 
rights in favour of another. The most active claimant was Germany with her dominant economic interests and her colonial ambitions already frustrated in Africa; the British were more reluctant, but the fears of Australia and New Zealand and wider diplomatic considerations could not permit German control of the island.

As Sylvia Masterman says, ${ }^{1}$ the hurricane "really brought the whole Samoan question before the world. People asked what was going on in Samoa that there should be all those warships there and that they should have acted so strangely and taken such risks? It became clear that something had to be done to help bring peace and order to the islands of Samoa."

The outcome was the "Berlin Conference on Samoan Affairs" of 1889. By the "Final Act" of the Conference, Samoa was declared neutral and independent and Malietoa Laupepa (who had been deported to West Africa by the Germans in 1887) was re-instated as head of a Samoan government. This government was empowered to legislate for the area beyond the town of Apia. Apia, which contained the majority of European residents, was granted a Municipal Council consisting of three Germans, two British and an

1 An Outline of Samoan History, Department of Education, Western Samoa, 1957, p.36. 
American, presided over by a German. The Conference also established a Supreme Court with a neutral Chief Justice, to deal with all disputes, the majority of which concerned land sales.

The Berlin settlement did little to stabilise Samoan politics. The Samoan claimants to the "kingship" continued to intrigue and in 1893 a rebellion - supported by the German authorities who had, during the 1880's, supported Tamasese against Malietoa - on behalf of Mata'afa resulted in that chief's deportation. There was a delay of several years before the new institutions began to function with any semblance of authority and even then a lack of finance prevented much that was constructive being achieved. In 1898, on the death of Malietoa Laupepa, the whole situation again flared up. Malietoa Tanumafili (the son of the former "king"), who was at school in Fiji, succeeded to the title of "Malietoa" and was proclaimed as King, although his claims were disputed by the Mata'afa faction. Mata'afa himself had been allowed to return to Samoa the previous year and he was now supported by a majority of Samoans. Notwithstanding a bombardment of Apia and nearby villages by British and American warships, Ma.ta'afa succeeded in driving the Europeans from Apia and establishing a "provisional government". The British and Americans still supported Malietoa. 
This dispute "gave the powers another chance"1 and in 1899 a Commission visited Western Samoa to inquire into the disturbances. Faced with the failure of the various experiments in alien supervision which Samoa had undergone in previous years, the Commission concluded that the only hope for peace and order lay in control by one European power. Great Britain, involved in war in South Africa, had no wish to annex Samoa and renounced her rights in the Group in favour of concessions elsewhere in the Pacific. The United States of America and Germany then partitioned the islands in accordance with their existing interests: the United States of America taking the Eastern part including the fine naval harbour of Pago Pago, and Germany the large plantation islands of Upolu and Savai'i with various smaller outlying islands.

The series of conventions recording these arrangements was signed on 16 February 1900, and on 1 March the German flag was hoisted.

\section{The German Period}

Germany's administration of Western Samoa was marked by a willingness to allow the samoans to continue their own way of life without interference by government, always

1 Department of Island Territories, Report on Western Samoa for the year ended 31 December 1958, (Parliamentary Paper A4), Wellington, Government Printer, 1959, p.10. 
provided that commercial development was uninindered. As early as the $1870^{\prime} \mathrm{s}$, German nationals had begun cultivation in Savai' $i$ and Upolu, and by 1900 most of the plantation properties on the islands were under the management of the Deutsche Handels und Plantagen-Gesellschaft, a government supported corporation with interests throughout the Pacific. "The firm", as Deutsche Handels und Plantagen-Gesellschaft was known, dominated Samoan affairs during the fourteen years in which the islands remained a German "protectorate"; cynically viewed, the government existed largely to maintain the conditions necessary for "the firm's" continued expansion. However, material achievements of this partnership were considerable: coconuts and cocoa planting was highly developed; rubber was introduced in 1906 and an extensive roading and bridging programme was carried out.

J.W. Davidson ${ }^{1}$ deseribes German policy in Samoa as one of "sympathetic and benevolent autocracy". Although its sympathy and benevolence might be challenged, there was little doubt of the Administration's autocracy. Instructions from the German Foreign office to the first

\section{Political Development in Western Samoa in Pacific Affairs, Vol.XXI, No.2, June 1948, p.139.}


Governor, Dr. Wilhelm Solf (formerly president of the Municipal Council), described Germany's rule over Samoa as "an independent appropriation of a territory which had lost its hitherto existing government; Germany did not acquire the islands as legal successors to the various former Samoan governments. ${ }^{1}$

Solf developed this policy in unequivocal terms in an address to the assembled chiefs at Mulinu'u (the traditional seat of the Samoan government) on 17 August $1900-$

"You all know that the former Governments of Samoa were not good and also not powerful: and no benevolence reigned among you and no friendships to each other, but seditions disquieted the land year for year.

Therefore the rulers of the three great powers decerned $\bar{s} i c 7$ and decreed that Samoa should be placed under the protectorate of His Majesty the German Emperor so that he may protect the beautiful archipelagus $|\bar{s} i \mathrm{c}\rangle$ with his strong arm ...

No body has to rule in the country except the Governor; his power extends over the white inhabitants of the islands and over you Samoans. It is not the intention of the German Government to force you to adopt our morals and our customs; the Government has a regard for your old traditions and respects them in as far as they do not give offence to the precepts of Christianity and the well being and safety of the single man.

1 Quoted by C.G.R. McKay, Historical Notes, Apia, 1935, (Cyclostyled), copy on I.T.2/15. 
The Government reposes the confidence in you that you are able to administrate $\overline{s i c} 7$ yourself under the supervision of the Goverñor, and there will be given such laws and ordinances as are to the best of the country and consonants, "I

In accordance with this policy the Governor established a system of district government based on the indigenous political organisation and also maintained at Mulinu'u an advisory body known as the Ta'imua and Faipule. This body had been the legislative organ of the Samoan Kingship and was dominated by the Tumua and Pule groups mentioned in Chapter I. The whole system of native government was designed to give full play - under the over-riding authority of the Governor - to the traditional features of Samoan politics. Effective government was expected at the village and district level but status and ceremony was paramount at the centre. The object of the Administration's native policy was frankly discussed by solf in a speech

delivered before the Reichstag in 1902 -

"The autonomy mentioned is founded on the patriarchal system. Districts were formed in which were put men with nice titles (the people think a great deal of titles)

Only a small part of the ... / poll7 tax has been paid to the officials in the shape of

1 Administration of Western Samoa - A Documentary Record and History of the Lauati Rebellion (0 Ie Mau Lauati), compiled from original Native office documents under the direction of A.I. Braisby, Inspector of Police, Apia, 1932-33, pp.1, 2 . 
salaries; the other part will be given to them as a present in the form of wagons for making roads: the better the road the larger the wagon presented to the respective chief official."I

The Governor was the fountain of all authority in German Samoa. The Samoan "kingship" had been abolished under the 1899 Conventions, with the concurrence of Malietoa, Tamasese and Mata'afa. Mata'afa, the strongest contender for the kingship - although the Germans had originally supported Tamasese - was appointed as Paramount Chief or "Ali'isili", a position which Solf made clear was subordinate to that of the Governor. The old assemblies of the native government Ta'imua, consisting of seven highest chiefs and Faipule, a council of chiefs and orators representing the traditional districts - were allowed to continue in the meantime. However, these "legislators" soon incurred the Administration's displeasure through their support of a native co-operative - the "Oloa". This venture, inspired by a young half-caste, had little prospect of success; its importance lies in the way in which it focused attention on the ambitions of Ta'imua and Faipule to assert their importance as the true leaders of Samoa.

1 Keesing, Modern Samoa, p.85. 
28.

In a manner foretelling the Mau of the late $1920^{\prime} \mathrm{s}$, the Ta'imua and Faipule, using their official influence, levied contributions or taxes contrary to the Governor's wishes or knowledge. Chiefs, imprisoned because they continued to organise the "Oloa" in disobedience of the Governor's orders, were released by parties under the leadership of the Faipule. The Administration's retaliation included the deportation of certain leading agitators and a wholesale revision of the policy and institutions of Samoan "self-government".

The appointment of Ta'imua ceased. New Faipule were appointed, but unlike their predecessors they were "paid officials". No longer were the Faipule to reside in permanent Council at Mulinu'u; they were to remain in their Districts, except when summoned to attend the Fono twice yearly. The Samoan gazette, "Savali", was established to communicate with the Faipule and pulenu'u (government representative in each village). The revised conception of Samoan policy was described by Solf in notes included in Braisby's compilation -

"It is part of the constituent nature of the Imperium that the person or body holding it may defer /delegate?7 such parts of its powers as he (or thēy) may dèem expedient to persons or a body of persons, which persons may or may not be called officials, but as long as they receive 
from the holder of the Imperium a reward, usually salaries, they are nothing else but officials, whatever their title may be. Officials are naturally bound to act according to the laws and to help to carry out the intentions of the holder of the Imperium." I

A further outbreak of agitation - usually known as the "Lauati rebellion" or the Mau of Savai'i occurred in 1908 and 1909. This was an attempt to assert the right to rule of the traditional political centres of Savai'i - the "Pule". Lauati, a person of considerable ambition, was deported with seventy-two others, including women and children, and died in Saipan in the Marianne Islands. Other government measures included the suspension for twelve months of all government officials in the disaffected areas, the confiscation of land and guns and the imposition of a penal tax on all matai in the rebellious districts. The enforcement of these punitive measures was aided by the presence of warships from the China station and 300 armed Melanesians.

The relations of the German administration with the European settlers, as with the Samoans, deteriorated after an initial period of quiet. To the majority of European residents in Samoa any government which ended the anarchy of the last few years of the international period 
was a good government. Germany soon achieved this and also took other measures which succeeded in keeping the citizens loyal for a time at least. There was considerable tolerance by the government of non-German elements, particularly the Missions. Although the Municipal Council was abolished, representatives of the European community, six to eight in number, nominated by the Governor were associated with senior officials in the Government Council (Gouvernemenstrat). This body was designed to advise the Governor and had no legislative functions. Non-German nationals were included in its membership.

However, as peace and security became accepted as the normal state of affairs, criticism of the Administration became more prominent. The complaints can be matched in every colonial territory; most were repeated when Samoa became New Zealand's responsibility. The Administration was inefficient; the officials were overpaid and excessive in number; the native policy was too soft; the taxes were too high; the Europeans should have some representation in the government. A less familiar complaint was that the government was dominated by "the firm". Apart from its participation in Samoan affairs which were the direct responsibility of the Governor the Administration carried out the minimal "housekeeping" 
functions of any government. Economic development was assisted by the admission and supervision of indentured labour; by action against pests (notably the rhinoceros beetle, accidentally introduced in 1911); and some agricultural experimentation. In health and medical work the Germans "laid the foundations of a modern health service, experimental and to some extent practical, though their work was concentrated in the Apia district and touched the whites and indentured labour more intensively than the native Samoans."I Similarly with education. This was almost entirely in the hands of the Missions. In 1904 a private school for education of Europeans (including part Samoan) children was taken over by the Administration and later in the period a school, under government supervision, was opened in Apia for local Samoan children. In 1908 a government high school was opened at Malifa behind Apia. The main purpose of this school was to train promising Samoans from both islands for positions in the public service. 2

1 Keesing, op. cit., p.379 (my italics).

2 See Ma'ia'i, Fanaafi, A Study of the Developing Pattern of Education and the Factors Influencing that Development in New Zealand's Pacific Dependencies, Wellington, 1957 (Unpublished Thesis, Victoria University of Wellington), p.169. 
Before concluding this brief account of the German rule in samoa it is necessary to mention the fact that the Protectorate had only two Governors during fourteen years. Dr. Solf, the first German Governor, had an experience of Samoan affairs matched only by Sir Alfred Turnbull (1931-1946) and the High Commissioner at the time of writing, Mr. G.R. Powles, amongst later administrators. Solf had been in Samoa for some years before 1900 as President of the Apia Municipality and he remained as Governor until his retirement in 1910. He later became Minister responsible for the colonies in the Reichstag. By all accounts he was an able man; he was tolerant and tactful and yet firm in dealing with all sections of the community. Solf was succeeded by his Deputy, the Chief Justice Dr. Erich Schultz, who also knew Samoa well. I

For this study the importance of the German period lies in the administrative pattern which it established. The conception of German policy was static; in the interests of peace, order and economic prosperity both European and Samoan sections of the community were to go their own ways without interference from each other or from government. If at any time the equilibrium was threatened,

1 His article The Most Important Principles of Samoan Family Law in Journal of the Polynesian Society, July 1911, is still regarded as authoritative. 
the Governor moved, at his discretion - and, if necessary, with the aid of warships - to redress the balance. The consequence of such a policy in later years has been "... the withdrawal of the Administration from the ordinary lives of the people ... the Samoan villager tends to regard government as being little more than a remote and impersonal system operating in Apia". ${ }^{1}$ Under the German Governors this was deliberate policy; under New Zealand rule the pattern re-emerged after unsuccessful attempts to channel the political energies of the Samoans into institutions more suited to Western ideas of development.

New Zealand - Military Occupation and the Early Mandate Years

Military occupations seldom lend themselves to administrative reorganisation and the New Zealand military administration in Western Samoa was no exception. Although New Zealand politicians had previously indicated territorial ambitions towards Samoa, the force of 1,360 under Col. Robert Logan, which landed in Apia on 29 August 1914, was embarked on a purely.military exercise. The original despatch received by the Governor-General made this quite clear -

1 J.W. Davidson, The Government of Western Samoa - Survey, (Prepared for Department of External Affairs, Wellington, 20 June 1947, Cyclostyled), p.I. 
"If your Ministers desire and feel themselves able to seize German wireless station at Samoa we should feel that this was a great and urgent Imperial service. You will realise, however, that any territory now occupied must at the conclusion of the war be at the disposal of the Imperial Government." I

The former German colony was occupied without opposition, and apart from the repatriation of the leading German officials and their replacement by officers of the Expeditionary Force, life in Samoa underwent little change. Particularly was this so in Savai'i where Col. Logan was able to reinstate as Deputy Administrator, Richard Williams - a British national who had, on the outbreak of war, resigned a similar post under the Germans. Williams, "... with no apparent support from the Force carried on the administration of the Island with marked success." 2

The main body of the Expeditionary Force was soon transferred to the European theatre and Samoa for the next five years settled into the pattern which is not unfairly described in the First Report of the New Zealand Government on the administration of the Mandate -

1 S.J. Smith, The Samoa (New Zealand) Expeditionary Force 1914-15, Wellington, 1924.

2 Ibid., p.86. 
"There thus were, irrespective of the indigenous inhabitants three concurrent organisations: firstly the garrison of the occupying force; secondly the Administration set up by the occupying force to carry on the Civil Government, which was a Military-Civil Administration, necessarily interwoven in its relations with the garrison; and, thirdly, the original community itself: consisting of traders, planters and others of German and many other races carrying on its activities as best it could and taking conscious and unconscious advantage in some respects of the organisation set up by the garrison."I

The attitude of the Samoans was summed up in a statement made in the Fono of Faipule convened by Dr. Schultz on the morning of the occupation -

"Samoa does not take sides in this; we stand by and allow the Great Powers to work out the will of God." 2

The Samoan officials appointed by the Germans were retained in office.

The Military Administration continued until

1 May 1920. By this date it was clear that New Zealand would retain control of Western Samoa, although the precise status of the former German Colony had not been determined. This delay and uncertainty in deciding Samoa's future reminiscent of the years before 1900 and of those

1 Mandated Territory of Western Samoa (First Report of the Government of New Zealand on the Administration of) for the Year Ended the 31st March 1921, Parliamentary Paper A4, Government Printer, Wellington, p.1. (Referred to hereafter as Parliamentary Paper A4 with the year in which the report was printed.) 
36.

immediately following World War II - was an unsettling factor of some significance. As early as January 1918, the Governor-General telegraphed the Secretary of State for the Colonies that "the Government of New Zealand are convinced that the retention of the German colonies is essential ... / and that7 this was the feeling of the Samoans". At the same time, the Governor-General sent a telegram to the Administrator in Samoa referring to the stress laid by Russia "on the right of a country to determine its own future and of the probability of a proposal to apply this in the case of the German colonies" and asking on behalf of the Imperial Government for "any evidence that you can give supporting the contention that the natives of Samoa appreciate and desire to remain under British rule". I

By despatch of 31 January, Col. Logan replied that a meeting of the Samoa Tojpna Club "a Native Commercial and Political Club composed of the leading Chiefs from every District in Samoa" attended by the Fautua (Malietoa and Tuimalealiifano) was "unanimous in wishing that Samoa should remain under British rule. They also told me that the Samoans had for many years wished to be under

1 File I.T.67/12/1 - (Samoa - Retention of by the British.) 
British rule, that it was a great disappointment to them when they were handed over to Germany under the Berlin Treaty and that they now rejoiced to be under the British flag." 1

This pro-British attitude began to waver as the year went on and the government still remained as a provisional Military Administration. E.W. Gurr (a resident of Samoa for many years) in a letter dated 23 November 1918 to his brother, N. Gurr of Dannevirke, wrote -

"There is a growing feeling amongst the native chiefs of Western Samoa to ask for annexation to the United States ... I know all New Zealand after all the sacrifice will be irreconciliably disappointed if Western Samoa is not under the control of the Dominion." 2

According to Gurr the change of heart was caused by a comparison "between the success of the natives of American Samoa I where the Government ran a marketing scheme7 and in Western Samoa with regard to their copra product". This letter was forwarded to Sir James Allen, who discussed it with Col. Logan when the Administrator returned to New Zealand early in 1919. A handwritten note on the file, initialled by Logan reads -

\section{Ibid. \\ 2 Ibid.}


"The matter is being worked up by H.J. Moors with the moral support of the United States of America Consul in Apia." I

Gurr's information was given more substance when at a talolo (welcome ceremony) to the new Administrator, Col. R.W. Tate, on 28 January a petition was presented praying for the transfer of the islands to American rule. The main evidence of New Zealand maladministration was held - justifiably as a later Commission of Inquiry proved - to be the inefficiency of the health authorities in permitting the worldwide influenza epidemic to be introduced into Western Samoa where its effects were disastrous, particularly amongst the older age group containing most of the influential matai. (By comparison, the neighbouring American territory applied quarantine restrictions and suffered no cases.) Eventually, on 15 February the Fautua together with another chief, Toleafoa, met the Administrator and asked that the petition be regarded as unreservedly withdrawn. The real reasons behind this petition - which did not have the support of all the districts of Samoa - and its withdrawal are difficult to find. Col. Logan believed that local Europeans were fostering the movement; Col. Tate thought that the 
petition was solely the creation of Toleafoa to distract attention from his failure to account for moneys received by him as sole "Managing Director" of the Toeina Club.

More important than these expressions of Samoan discontent was the reaction of the European community to New Zealand's action prohibiting the importation, manufacture or sale of intoxicating liquor.

"In 1919, after the Covenant of the League of Nations had been published, and in anticipation of the issue of the Mandate, a Proclamation was issued prohibiting the further importation of intoxicating liquor and shortly afterwards total prohibition became a fundamental portion of the Constitution. Prohibition was imposed in what was considered to be the best interests of the community, but it was received with great dissatisfaction by a considerable portion of the community other than Native. This accentuated a state of mind already existing in the community of antagonism to administration by New Zealand, and to any constitution which New Zealand might set up."I

The local Europeans demanded exemption from prohibition for themselves without prejudice to the question of its imposition on the Samoans. Successive New Zealand Ministers were unwilling to accede to this demand on two grounds: first that it was impracticable to distinguish between "Europeans" and Samoans when many persons of "European" status were living in the same households and

1 Parliamentary Paper A4, 1921, p.2. 
in the same manner as Samoans; and second that it would be unfair and inconsistent with the spirit of the Mandate to distinguish between the sections of the community. The second ground has little validity, but the difficulties of administering any scheme of liquor control have even now proved beyond the resources of successive Samoan Governments.

If the imposition of prohibition, in itself, did little to assist the Administration's cause, it left the residents of the Territory in no doubt as to what that cause was. Article 22 of the Mandate enjoined New Zealand "to promote to the utmost the material and moral well being and the social progress of the inhabitants of the Territory". New Zealand, "the most single-minded of all the Mandatory Powers" ${ }^{1}$ interpreted "inhabitants" as fullblooded Samoans, the great majority of the population. Thus in the fourth Mandate Report 1923/24, the Administrator said -

"The policy of the Government to give primary consideration to the interests of the Native race in all matters of administration is being strictly carried out."

Throughout the period covered by this study the policy of "Samoa for the Samoans" - ironically adopted later

1 Toynbee, A.J. Survey of International Affairs, London, 1927, p.402, quoted by Stanner, W.E.H. The South Seas in Transition, Sydney, 1953, p.274. 
as the motto of the Mau - lay behind all the activities of the Administration. One cannot but share Keesing's doubts of the wisdom of the almost puritanical singlemindedness with which this policy was carried out -

"IIt7 undoubtedly cuts across the aspirations of non-native and part-Samoan groups, who, consciously or otherwise, react as though it were threatening to their interests. The question arises whether this is really wise, not only for the sake of being fair to such residents, notably to the part-Samoans who after all are equally as indigenous as those of comparatively full Samoan blood but also as regards the practical task of carrying on administration successfully." I

Col. Tate (the first Civil Administrator) is reported to have told the Faipule that he wished to be remembered as the"man who went slowly"; he conceived his main task to be the re-establishment of confidence in New Zealand administration in a period of post war economic and social disturbance. While he was Administrator considerable progress was made in public works, financed by loans and grants from New Zealand; the health and education services were developed with the assistance of subsidies from New Zealand (later recovered); and the Crown Estates taken over as reparations from their former German owners (including D.H. \& P.G.) were rescued from the rundown condition into which they had fallen at the end of the war.

1 Keesing, op. cit., p.106. 
In the administrative field, Tate had begun to build up the Fono of Faipule as an instrument by which the people and the Administration could keep in touch. But primarily he was content to carry on a policy of gradual development which was hindered, in his opinion, by a lack of financial support from Wellington.

Col. Tate was replaced as Administrator by Major-General G.S. Richardson C.B., C.M.G., who arrived in the Territory on 16 March 1923. Richardson soon established the principles which he retained throughout his eventfuI administration -

"The Natives are loyal, happy and contented; they are proud to be associated with the British Empire ... The Samoan has, however, no thought for tomorrow, and no vision as to the future of these islands. He does not realise that in the economic progress of Samoa he must play a greater part in future for its development if he is to remain the dominant race. The excellent education that is now being given to the young will change the psychology of the Samoan of the next generation ... Here in Samoa is a splendid but backward Native race." I

The picture of Richardson which this extract conveys single-minded in his desire to assist the Samoans; optimistic in his faith in the ability to "change the psychology of the next generation"; paternalistic and intolerant of those who do not share his faith - seems

1 Administrator to Minister, 10 May 1923, reprinted with Parliamentary Paper A4, 1923. 
a fair one. Perhaps it was to be expected from facts of his own rather remarkable career. He had begun in the ranks of the British Army; had been seconded, as a sergeant, for service under the New Zealand Government as an instructor and had risen to his present position after thirty years of this service, which had culminated in a distinguished war record. It is understandable that Richardson should believe that nothing was impossible, given the requisite amount of hard work and ability and a willingness to make the best of opportunities when they offered. It is also not too much to be wondered at that Richardson did not possess the qualities of diplomatic negotiation, tact and patience required to handle the complex personalities and situations with which he was faced in Samoa.

Apart from the political innovations which are described in detail later in this study the Administration, under Richardson, "in carrying out the policy of the New Zealand Government to promote to the utmost the interests of the Samoan race ... concentrated its efforts upon three essentials viz: (1) Health, (2) Education, (3) Agricultural Development."I The greatest achievement was in health. The average rate of natural increase in 
the Samoan population between 1919 and 1926 was more than three times as great as the average rate of increase 1887-1917; systematic campaigns were conducted for the eradication of formerly endemic diseases such as yaws and hookworm, and for the improvement in sanitation; public health work was carried into the districts and additional dispensaries and outstations were maintained by the Health Department. The health services, which were financed by a head tax on all matai and taulele'a (imposed with the consent of the Fono of Faipule) and by New Zealand subsidy, received high praise from outside observers.

In co-operation with the Missions and with the aid of an annual subsidy from New Zealand the system of district schools was extended. Government agricultural schools were maintained at Avele near Apia and Vaipouli in Savai'i. Education for selected pupils from Avele and Vaipouli was continued to New Zealand Proficiency standard at Malifa school, while European children attended the Leifiifi school in Apia. The number of children attending school continued to increase, apart from a short setback during the political unrest of the late 1920's. A comment by Mr. W.W. Bird (a former Senior Inspector of Native Schools) who visited Samoa in 1920 and 1929, is significant - 
"I believe the schools exercise considerable influence in Samoa and there is no government activity which is so much appreciated by the people." I

The extension of health and education services was easier to carry out than innovations in economic organisation. The Administration, under both Tate and Richardson, undertook quite vigorous programmes of agricultural education and extension work. Exhibitions were held to stimulate trade. Regulations regarding planting, distribution of seed for experimental purposes, and campaigns against the rhinoceros beetle and the flying fox were enforced by agricultural inspectors. The Samoans were encouraged at every opportunity "to utilise their lands for something more than the mere growing of food; namely, to produce copra and other agricultural products for export". 2

The export figures show that these efforts met with some success up to 1927. In his annual report for the year ended 31 March 1927, Richardson was able to say "The prospects for the ensuing year are particularly good, as the plantations nearly all show signs of fairly heavy crops. New areas of coconuts are coming into bearing. Cacao plantations have recovered from the blow of last year, and the trees are bearing well. All the rubber

1 Quoted by $\mathrm{Ma}^{\prime} i \mathrm{a}^{\prime} i$, op. cit., p.203. 
plantations excepting one owned by a private company are being developed. Larger areas of cotton are being put under cultivation, and extensive planting of bananas has been carried out in preparation for the proposed export of fruit to New Zealand. It is hopefully anticipated, therefore, that this will be a record year for trade." 1

Similarly, in a pencilled note of 23 september 1926 to Gray, the Secretary of External Affairs, Richardson was able to say with regard to the forthcoming visit of the Minister -

"Personally I know of no complaints or grievances save that Nelson \& Company would like to abolish the Fono of Faipule and run native affairs in the Council ... I know of absolutely nothing which the Minister will have to deal with ...." 2

Unfortunately 1926 marked the end of the progressive period of New Zealand's Mandate, and the beginning of nearly twenty years first of "non co-operation" and then of marking time.

The Mau

The definitive history of the Mau has yet to be written. In an introductory chapter such as this, the treatment must unfortunately be confined to a chronological summary and a brief and inadequate indication of the causes of this movement which dominates Samoan history under the Mandate. 
The genesis of the Mau is usually held to date from September 1926 (about the same time as Richardson's optimistic note quoted on $\mathrm{p} .46$ ) when O.F. Nelson, Apia's leading businessman and the First Elected Member of the Legislative Council, returned to Samoa after a lengthy visit to Australia and New Zealand. Nelson, while in Wellington, had interviewed the Prime Minister and the Minister of External Affairs (W. Nosworthy) concerning the Native policy of the Administration and other less significant matters. At the interview it was agreed that Mr. Nosworthy should visit Western Samoa in the near future. (No Minister of External Affairs had visited Samoa since Hon. E.P. Lee in 1922.)

Nelson returned to Samoa on 24 September 1926; on 25 September at a private meeting with a number of partSamoans and Samoans who later became prominent in the Mau, it was decided that public action should be taken against the Administration; on 26 september the Administrator eulogistically welcomed Nelson home to Samoa at a public reception; on 15 october a public meeting attended by Europeans and Samoans and sponsored by Nelson and his two elected colleagues on the Legislative Council reached the following "decisions" - 
"(1) That a document be prepared setting out the matters of dissatisfaction among all people in Samoa, and to be conveyed to the New Zealand Government.

(2) That a committee consisting of 6 Samoans, 6 whites, and the 3 Legislative Councillors be appointed.

(3) That a wireless message be sent to New Zealand asking that the Minister be sent to Samoa in November.

(4) That the following matters be recorded -

I. That Faipules (FP) be appointed on the Legislative Council.

II. (a) That the accounts (money matters)

of the Government of Samoa be enquired into; that the white officials be decreased and their salaries.

(e) That the debt of the Samoa Government to New Zealand be inquired into: where has this money gone?

III. The appeal of the white people for the re-establishment of their custom concerning Iiquor.

IV. (a) The appeal of the Samoans against the cruel oppressive despotic authority of the Government in taking away titles of chief's' names and the banishment of chiefs to villages other than their own.

(e) That the Samoans are dissatisfied with the hospital tax.

(i) The distress of the Samoans because of the many cruel oppressive despotic laws prohibiting some of their important Native customs. 
(o) The strong restrictions on customs that give prestige to the $A I^{\prime} i$ and Faipule such as "fine mats".

(u) The prohibiting of Samoans of other villages from living in Apia, where they get work, whether married or not."I

The "Citizens" Committee" appointed at this meeting consisted of Messrs. Nelson, A. Williams M.L.C., G.E.L. Westbrook M.I.C., E.W. Gurr (a journalist of long residence in the Samoan Islands), A.G. Smyth (an Apia trader), Baxter (a local solicitor), Cobcroft (a planter), S. Meredith (a trader), K. Meyer (planter). The Samoans associated with the committee were Lago Lago, Faumuina, Ainu'u, Tuisila, Alipia and Tofaeono. (Messrs. Baxter, Cobcroft and Meyer subsequently resigned from the committee; the two latter, although dissatisfied with certain Administration policies, disclaimed any intention of involving the Samoans in their complaints.)

Various sub-committees were appointed to report back to a further public meeting called for and held on 12 November. At the beginning of this meeting the Acting Secretary to the Administration intervened to ask leave to read aloud a letter from the Administrator. It was a warning addressed to both Europeans and Samoans to the

1 Western Samoa (Report of Royal Commission Concerning the Administration of) Government Printer, Wellington, 1928, p.421. 
effect that the Administrator could not approve of a political meeting which involved the Samoans in European politics, as its tendency could only be to disturb the peace, order and good government of the Samoans. After a pause the meeting continued, heard the reports of the sub-committees, and decided to send a deputation to New Zealand in January 1927. (The visit of Mr. Nosworthy had been deferred until the following May.)

In reply to a telegram sent by the second meeting, the Minister said -

"I will be prepared to receive delegation in January but $I$ will not consider any representations with respect to Samoan affairs until they have been first submitted to His Excellency the Administrator for report or until I have had an opportunity of personal investigation in consultation with His Excellency during my forthcoming visit. Any representations must similarly be submitted through the Fono of Faipule and Administrator." I

Permits to leave Samoa were applied for by the six Samoan members of the Citizens' Committee but were refused by the Inspector of Police on the grounds that under the terms of the Minister's reply they would not be received by the Government in Wellington. Eventually, Mr. S. Meredith proceeded to New Zealand in January 1927 and while there published and circulated a pamphlet "How New Zealand Administers its Mandate from the League of Nations". This

1 Telegram of 16 November 1926 on File I.T.1/23/8, op. cit. 
pamphlet, published at p.422 of the Royal Commission Report, criticises particularly the impotence of the Legislative Council and the Fono of Faipule vis-a-vis the Administrator, the enforcement of local "banishment" orders, the insistence of the Minister in refusing to deal with Samoan matters except through the Administrator and the Fono and finally the apparent reluctance of the Minister to visit Western Samoa. The pamphlet closes with the plea that "the citizens of Samoa have therefore no other course than to appeal to the public of New Zealand, and their elected representatives, for a rudimentary measure of justice which is at present denied them ..." In the meantime, "Mr. Nelson ... formed a further and supporting committee, consisting exclusively of Natives ... This supporting committee evidently became numerically very large, and it is said that it contained representative Samoans from every Faipule district of Western Samoa."I This was the beginning of the Mau proper - a Samoan organisation which, although inaugurated and encouraged by local Europeans, persisted in peculiarly Samoan form long after the causes of the initial grievances had been removed.

1 Royal Commission Report, op. cit., p.xxili. 
In the seven months between the second Citizens' meeting in November 1926 and the arrival of Mr. Nosworthy on 2 June 1927, European agitation continued and the Mau gained increasing influence amongst the Samoan population. The Administrator took some time to realise the significance of the movement. Writing to the Minister on 22 October 1926, he was still able to dismiss it as "merely a small agitation to boom up the Elected Members in view of the forthcoming election. You can trust me to handle it satisfactorily." I

As early as November 1926, delegates of the Mau committee were in Savai'i collecting subscriptions and distributing copies of circulars relating the work of the committee. In March 1927 a petition was prepared purporting to be from "the chiefs and orators of Western Samoa who have been authorised to represent the large majority of the Samoan people owing to their increasing dissatisfaction with certain features of the New Zealand administration in Samoa." 2 The petition, which was later presented to the New Zealand Parliament, was not mentioned in the discussions between the Minister and the Citizens. Committee.

1 Administrator to Minister, I.T.1/23/8, op. cit.

2 Royal Commission Report, op. cit., p.xxilii. 
At the first of these discussions on 11 June, Nelson as Chairman of the Citizens' Committee presented the reports endorsed at the November 1926 public meeting and read a prepared statement summarising the committee's grievances. The Minister, who does not come out well from the minutes of these discussions, ${ }^{1}$ asserted the New Zealand policy of placing the interests of the Samoans first and foremost and of refusing to deal with Samoan matters except through the proper constitutional channels. After Mr. Nosworthy had left Apia on 14 June, the Administrator forwarded to Nelson two letters from the Minister. The first informed the Citizens' Committee that no consideration would be given to their request "that permission be given for a deputation to visit New Zealand for the purpose of petitioning Parliament with respect to Samoan affairs" until the Minister was satisfied that the committee had taken action "to cease your present agitation in the attempt to disunite and disaffect the Samoan people, and to undo the trouble you have already caused".2 The second letter informed the committee that an amendment was to be made to the Samoa Immigration Order to enable the Administrator, if so directed by the

1 Copies of the minutes are on I.T.1/23/8, op. cit. 2 Royal Commission Report, op. cit., p.445. 
Governor-General in Council, to order any person to leave Samoa in certain circumstances. The letter went on to warn the six European members of the Citizens' Committee that they would be deported unless they were to "not only forthwith cease from your present activities with regard to the Native people, but satisfy His Excellency the Administrator that you are doing your utmost to undo the trouble that you have already caus ed". 1

Richardson, on 20 June, informed the committee that he was not satisfied with the truth of the committee's assurance that they had "requested the natives who had assembled at Apia to learn the Minister's decision, to return quietly to their homes and to respect the law" and that they had "ceased from activities with regard to the native people" in accordance with the Minister's demand. On 24 June, Richardson warned both Nelson and Smyth, who were about to sail from Apia for New Zealand, that they might suffer immediate deportation upon return because "I am not satisfied that you have used your best efforts to undo the harm done".

Nelson arrived in Auckland on 11 July 1927, bringing with him the petition prepared in March. The petition was referred to a Joint Committee of both Houses of 
Parliament and evidence was taken from Nelson. The committee experienced difficulties through the nonavailability of other witnesses and on 5 September the Government, in response to a request from the Administrator, appointed a Royal Commission consisting of Sir Charles Skerrett, Chief Justice of New Zealand as Chairman, and Judge McCormick of the Native Land Court of New Zealand. The Commission's order of reference was -

"1. Whether, having regard to the duties undertaken by the Government of New Zealand under the said Mandate, there is just or reasonable cause for such complaints or objections /ās contained in the Petition to Parliament, reproduced as Appendix No.l of the Commission's report7.

2. Whether the Administrator or the officials of the Administration have in any manner exceeded their duty in the exercise of the authority entrusted to them respectively, or have failed to exercise their respective functions honestly and justly.

3. Whether having regard to the Samoan Native Customs and to the due maintenance of government and order in the Mandated Territory it would be prudent or safe to wholly repeal and abrogate all power to require a Samoan to remove for a definite period from one place on the islands to another." 1

In its report of 29 November 1927, the Commission (which heard extensive evidence in Western Samoa) divided complaints against the Administration into two main classes. First, those "more specially affecting the trading and

1 Royal Commission Report, op. cit., pp.i, ii. 
business community" including prohibition, the Administration's copra marketing scheme and extravagance in the Administration's finances. Concerning the first two subjects the Commission found that both were matters of policy and outside its terms of reference; as to the charges of extravagance the Commission was of the opinion that "the sole ground on which the complainants based their charge ... was on their own admission, cut away from them /by gross inaccuracies in the figures submitted in evidence7. We may add that nothing was elicited as evidence which would justify us in thinking that the Administration was overstaffed or overpaid ..."I The Commission went on to say "there can be no doubt that the foundationless statements contained in the report read at the meeting /or 16 November 7 and probably circulated in other ways amongst the Natives, caused them to believe that the expenditure of the Administration was grossly extravagant ..." ${ }^{2}$

The second category of complaints dealt with by the Commission - those relating to "acts of the Administration with respect to Native affairs and to the part directly or indirectly taken by Samoans in the government of the Territory" ${ }^{3}$ - are more important for the purposes of
1 Ibid, p.xi.
2 Ibid, p.xiii.
Ibid, p.vi. 
this study. By the time the Commission was appointed, the Mau had taken on the form of "non co-operation" which was to persist for another decade. According to the Commission -

"These actual consequences of the Mau organisation were really not in dispute before us. It was clear to us that there was an organised and deliberate attempt to frustrate and render abortive the activities of the Administration, and ultimately to set up a Samoan Government There was an organised refusal among the members of the Mau to obey the laws and regulations. There was an organised refusal to recognise the authority of the Faipules and pulenu'us and inspectors of plantations. Generally speaking there was an organised refusal to destroy the rhinoceros beetle, although in some districts the beetles were still being caught, but handed over to committees appointed by members of the Mau. There was an organised refusal to attend District Councils and to send their children to the Government schools. There was a further organised refusal to attend the malagas of the Administrator and the Resident Commissioner: and to recognise the authority of Native Magistrates." 1

Much of the detail covered in the Commission's report will be discussed in Part II of this study. At this stage it is sufficient to quote the opinion of the New Zealand Government, as expressed in the Annual Report for the year ended 31 March 1928 -

"The Commission's report ... contains a complete vindication of the Administration, and a trenchant criticism of the weakness of the complainants' case and of the methods adopted by the committee to foment disaffection in Samoa." 2

1 Ibid, p.xxv.

2 Parliamentary Paper A4, 1928, p.3. 
In the meantime, the activities of Nelson, who was still in New Zealand, continued to thwart the Administration's attempts to reassert its control of affairs in the Territory. Increasing numbers of Mau adherents congregated in the village of Vaimoso, just outside Apia, in anticipation of the good tidings which were to result from Nelson's trip. Although few Samoans were articulate in their expectations, there was undoubtedly a quite widespread belief that "Taisi's" mission would secure the termination of New Zealand's Mandate (and presumably a reversion to a truly Samoan government). As Richardson was well aware, this situation could only lead to a trial of strength between the Administrator and the Mau. As early as 27 August 1927, he wrote to the Minister saying -

"The principle which I have tried to uphold viz: that Native matters must be dealt with through their own representative and myself has not, unfortunately, been upheld by the Government, and $\mathrm{Mr}$. Nelson has appeared in the public eye as one who is championing the cause of the Natives whereas he is really working only for his personal interests. This is recognised here by the European community, but does not appear to be understood in New Zealand. The Faipules are disgusted at Mr. Nelson's apparent influence with the New Zealand Government. They are annoyed that he should have been permitted to speak on behalf of the Natives who thought the Administrator strong and powerful enough to prevent Mr. Nelson's tactics, have joined the 'Mau' and the prestige of $\mathrm{New}$ Zealand has suffered considerably in their eyes. It will be a difficult matter for me to restore that prestige ... To speak of 
militaristic methods being employed here is a gross libel, intended deliberately to injure one who is working for the good of the Natives. The Administrator has no real power to do anything here, if his authority and good name are not upheld. His power is absolutely nominal. In a village where the Chiefs have been told by Mr. Nelson not to give in, not to go near the Administrator etc.e the police are unable to effect an arrest for an offence. The police here cannot use force even if they were ordered to do so." I

Richardson now resorted to the most substantial sanction at his command for asserting his authority over the Samoan population - the power of ordering local "banishment". On 20 June, orders were made requiring Lago Lago, the leading Samoan agitator, and Faumuina, an influential chief associated with him, to leave their villages near Apia and to remain, at the pleasure of the Administrator, in the small island of Apolima. This action provoked a letter dated 21 June from a number of Samoans "the committee elected by the Mau of Western Samoa to act on its behalf" - asking for an investigation into the Mau grievances before the deportations were carried out and threatening "a disturbance of the peace if the deportation takes place before an investigation is made to clear up the matter for the benefit of the people". 2 After a

1 Administrator to Minister on File I.T.1/23/8, op. cit., (my italics).

2

Royal Commission Report, op. cit., p.432 
further exchange of correspondence, in which the Administrator said he would be pleased to hear Samoan representations during his forthcoming malaga, the committee on $5 \mathrm{July}$ informed Richardson that they had decided to remain gathered together in Apia until they received the decision which they were expecting and none would depart until the answer they were waiting for was received.

Richardson then made orders "banishing" from the Apia area some fifty individuals and depriving thirteen chiefs of their matai titles. The Royal Commission found that "the Administrator was right in his opinion that the organisation of the Mau as understood and used by the Natives could not exist alongside of and concurrently with the administration of the country under the Mandate. One or other must give way."I In the event it was the Administrator who had to give way; some 39 of the "banishment orders were disobeyed and it was found advisable not to enforce them". 2

The Mau now became more bold and several hundred uniformed "Mau Police" began to picket shops in Apia. At this stage the New Zealand Government, although somewhat reluctantly, were persuaded by the Administrator to take

$$
\begin{aligned}
& 1 \text { Ibid, p.xIi. } \\
& 2 \text { Ibid, p.xI. }
\end{aligned}
$$


action under the powers of deportation recently enacted. On 23 December 1927 it was officially announced in Wellington that the Administrator had been authorised by Order in Council to require Nelson (who had now returned to Apia) and Gurr to absent themselves from Western Samoa for five years and Smyth for two years. The deportees sailed in January 1928. At the end of December, Westbrook, Williams and Meredith (the other leading members of the Citizens' Committee) were required by Richardson to meet the Apia committee of the Mau and to submit proposals to the Administrator for inducing the Mau to disperse. This action did not have the desired effect; and, in a statement issued on 23 January 1928 Coates, the Prime Minister, admitted that -

"Our administration of Samoa has for many months past been very largely ineffective. In Samoa today the native people are seriously disunited. A large section of them are in a state of passive resistance to constituted authority. So far as they are concerned, the King's writ is not running." 1

This statement marks the beginning of a more determined attitude towards the Mau on the part of New Zealand. After both Richardson and the Faipule had been rebuffed by the Mau chiefs and after several incidents in which the "Mau Police" had resorted to intimidation, the New Zealand 
Government despatched two warships of the New Zealand Division. On 23 February the cruisers "Diomede" and "Dunedin" landed detachments of Marines, who arrested without resistance some 400 "Mau Police". The prisoners were tried and sentenced to six months' imprisonment; Richardson met the prisoners in gaol and after fonos, which lasted for several days, allowed them to return home on the condition that they would observe law and order and disperse the Mau. On the day following the prisoners' release the leading chief of the Mau party, Tamasese, told Richardson that they did not intend to end the Mau and that they would not accept the institutions for local government set up by the Administration. "All they wanted was 'Samoa for the Samoans' and to govern the country themselves." 1

Although the Mau ceased their boycott of Apia stores, the committee remained in Apia receiving and circulating propaganda mostly originating in Auckland. They were determined to remain until Nelson returned "with victory". The New Zealand Government at this stage decided that Sir George Richardson should appear before the Permanent Mandates Commission of the League of Nations. Richardson's term as Administrator, which had already been extended once, 
was to expire on 31 March 1928. In view of Richardson's appearance in Geneva and the necessary long absence from Western Samoa, the Government appointed as Administrator, Col. S.S. Allen, who took up his duties on 4 May. Richardson in due course appeared before the Thirteenth Session of the Permanent Mandates Commission (12-29 June 1928) which also had before it several petitions relating to Samoa, including one from Nelson. In reporting to the Council of the League, the Commission gave its "considered opinion ... that none of the charges of any importance against the Administration which have been made in the various petitions has been substantiated ... The Commission cannot too strongly condemn the action of Mr. Nelson and those associated with him ... The Commission is satisfied that the Administrator acted with great patience - if not perhaps always with sufficient psychological insight ... The lamentable absence of sufficient means to enforce the law which it was his duty to uphold placed him in an extremely difficult situation ..."I

In the meantime, Col. Allen had been provided with a larger supply of force than Richardson had had at his command. Although the warships had remained at Apia for only three weeks, a force of Marines had been left for a 
further six weeks; in April 1928 these were replaced by

a force of 74 New Zealand military police. With this

support the Administration was able to take a firmer line

in enforcing law and order. A number of arrests were

carried out and on only two occasions in 1928 did serious

conflict between the police and the population occur.

Only minor injuries were sustained on each occasion. In

the annual report for the year ended 31 March 1929 the

new Administrator reported -

"The Native unrest continues, and the organisation still contains some two-thirds of the Native population. This is reflected in the revenue from Native taxes, which has produced for the year ended 31 March 1929, the sum of $£ 6,343$ out of an estimated return of $£ 19,400$. In spite of the diminution in Native tax receipts, the activities of the Administration on behalf of the Samoan population by way of education and medical treatment have been fully maintained ... The attitude of the Mau has changed during the year from one of ostentation and aggression to a more subdued form, but the same difficulty in dealing with it persists. To effect arrests on any charge is rendered difficult by the offender either running away to the bush or being concealed by his friends; and though the criminal law has been fairly well enforced, there are still a number of offenders at large. The collection of taxes by civil process has been impossible to deal with and more prominent individuals only /Including Tamasesel have been singled out for attention." 1

In November and December 1928, a New Zealand investigating team of P.D.N. Verschaffelt (Public Service Commissioner), A.D. Park (Assistant Secretary to the Treasury), 
and C.A. Berendsen (Secretary of External Affairs) visited Samoa to report to the Government on the finances and staff of the Administration. Their report ${ }^{1}$ was highly critical of extravagance and inefficiency of the administration under Richardson. Although many of their strictures were undoubtedly justified, the economy minded attitude of this Mission towards the provision of social services for the Samoans was a spectre which haunted the administration of the Territory for another twenty years. Their report also provided the Administration's critics with valuable ammunition.

Partly in line with the recommendations of the Verschaffelt-Park-Berendsen Report and partly because the existing system of district and village government had broken down, Allen instituted a number of administrative changes; the Fono of Faipule and the Faamasino's (or District Judges) were suspended and District officers from the ranks of the Military Police were appointed to perform the duties of District Councils and of the Faipule in the districts.

"Until November 1929, it seemed as if the Mau was slowly dying out." 2

I Parliamentary Paper A4B, 1929.
2 Parliamentary Paper A4, 1930, p.3.


However, in that month two of the highest ranking Mau chiefs - Tuimalealiifano (a Fautua until joining the Mau in April 1928) and Faumuina - returned from New Zealand where they had been giving evidence in a libel action brought by Nelson against an Auckland newspaper. The two chiefs -

"brought back with them such glowing accounts of the support they had received in New Zealand and of all Mr. Nelson was doing there, and they promised a 'victory' to the Mau with so much confidence that the Mau was resuscitated and renewed its activities in their worst form. Traffic on the road through Vaimoso and Lepea was impeded, passing cars were stoned, indecent exposures to passers-by were made, loyal Natives were intimidated, fines were inflicted on Natives who supplied copra to stores other than those owned by Messrs. Nelson \& Co., Native policemen were assaulted, malicious damage was done to telephone lines and other Government property, fines were imposed on those who took cases before the Land and Titles Commission, and petty tyranny resorted to in every possible way in those villages in which the Mau predominated."I

The first deaths by violence resulting from the unrest occurred on 28 December 1929 - "Black Saturday" - at a procession of Mau adherents held in honour of Smyth, whose term of deportation had expired on 22 December. The crowd resisted an attempt by the police to arrest persons prominent in the procession, against whom warrants had been issued. One European constable (Abraham) and 
eleven Samoans, including those who died of wounds later, lost their lives. Included in the latter was the high chief Tamasese. A magisterial inquiry later held that the police action in using firearms was justified in the circumstances.

The events of 28 December immediately led the Administration to take stronger action. Public notices, signed by the Administrator, were posted proclaiming that Samoans not usually resident within certain designated areas were to return to their own homes by 11 January. Fifty-eight Samoans, whose names were listed in the notices, were required to meet the Administrator on 8 January. Twenty others, charged or connected with various offences whose arrest had been hindered by the Mau, were required to surrender by the llth to the police at Apia. On the 8 th the cruiser "Dunedin" sailed for Samoa. The order to leave the designated areas was obeyed (although those who obeyed it left these areas only to reassemble elsewhere). The Samoans who had been ordered to meet the Administrator and to surrender to the police failed to do so. Whereupon the Samoa Seditious Organisations Regulations 1930 were brought into force by Order in Council on 11 January. These Regulations enabled the Administrator to proclaim the Mau, or any movement in its place, a seditious organisation. 
On 12 January the "Dunedin" arrived, and landing parties went ashore the following day; on the same day, the 13th, the Administrator proclaimed the Mau a seditious organisation, thus rendering any person associated with it liable to imprisonment for a term not exceeding twelve months or to a fine not exceeding $\{200$. This caused the leaders of the Mau to take to the bush with the police and Marines in pursuit. The annual report of 1930 estimates the number of Mau Samoans in the bush as 1,200 to 1,500; the Administration force numbered some 150 Marines and seamen from the "Dunedin" and approximately 50 members of the Samoan constabulary, which had replaced the Military Police. (In addition, a number of loyal Samoans assisted in the campaign.) Although a number of arrests were made, the Mau did not break up and a further attempt was made to seek a direct understanding with the leaders.

Largely through the mediating influence of several missionaries, a number of the leading Mau chiefs agreed to meet the Administrator in company with the New Zealand Minister of Defence (Hon. J. Cobbe), who had been sent by the Government to confer with Allen. The Mau chiefs were guaranteed immunity from arrest for the purpose. The meetings, which took place at the former Mau headquarters at Vaimoso on 3, 4, 5 and 7 March, were attended by the 
Administrator, the Minister, the Commodore commanding the New Zealand Naval Station (Capt. Blake R.N.), Commander Jeffreys R.N., the Secretary for Native Affairs (Mr. F.G. Lewis), Faumuina, Tuimalealiffano, Tamasese (brother of the chief killed on 28 December 1929) and the two Fautua, Malietoa and Mata'afa. The Administrator put forward three proposals: that the Mau should dissolve; that the persons against whom warrants had been served should be surrendered; and that, whenever necessary, leading representative chiefs should meet the Administrator to discuss with them all matters that concerned the welfare of the people.

Faumuina, on behalf of the Mau, replied that the Mau would not dissolve but would disperse from Apia, and that the wanted men would be given up. No reply was received to the third proposal. Following this meeting the New Zealand Government was able to state in the annual report for the year ended 31 March 1930, that -

"the situation in the Territory is now / $\overline{2} 8$ July 19307 greatly improved, and no difficulty is being experienced in enforcing law and order. There is good ground to hope that co-operation with the Samoans of the Mau will be feasible at no distant date, though the possibility of isolated incidents cannot be ignored."I

1 Parliamentary Paper A4, 1930, p.I. 
In the report for the year ended 31 March 1931 it was recorded that -

"Native unrest has steadily diminished during the year, and as it died away several of the known agitators left the country and the discordant element has become less conspicuous ... The position now is generally satisfactory. Increasing peace and harmony prevail. The active phase of the Mau appears to have ended, and there are few Samoans taking any interest in it. There is still a passive phase, in which co-operation with the Administration is not complete, but in almost every district the Samoans are now working together and uniting in all their former normal relations, among themselves and with the Administration officials in all local affairs."I

Some sixty Mau chiefs, including the 84 year old high chief Tuimalealiifano, gathered in an attempt to resume Mau activities as soon as the Marine detachment left in April 1930, but were promptly arrested, and although later there were other similar attempts to revive the Mau there were also definite signs of a rapprochement. In accordance with the undertaking given to the Mau in March 1930, the Administration called a representative fono to meet at Mulinu'u in June; a number of Mau chiefs attended the fono which asked for the reconstitution of the Fono of Faipule. New Faipule were nominated by the districts for a one year term and a Fono held during November. The Mau also participated in the proceedings of the land and Titles

Parliamentary Paper A4, 1931, pp.3, 4. 
Commission, a body which they had previously boycotted. An important counter attraction to the Mau, which also served to unite many factions, was the centenary of the landing of John Williams in Savai'i in 1830 and the beginning of London Missionary Society activities in Samoa. Large gatherings were held at Sapapali'i in Savai'i and Malua near Apia.

Col. Allen left Samoa on $4 \mathrm{April} 1931$ and his successor, Brigadier-General H.E. Hart, arrived on 1 May 1931. The political situation remained quiet in the first two years of his term; little attempt was made to enforce the restrictive measures against the Mau and no effort was made to enforce the payment of taxes or to extend the activities of the Administration. The headquarters of the Mau were now in Auckland and the propaganda paper "The Samoa Guardian" continued to keep up the hopes of the Samoans. In May 1933, Nelson returned to Samoa on the completion of the period of five years for which he was deported in December 1927. "Immediately thereafter political agitation revived. It grew in strength until early in November, when two parties of Samoans undertook a tour of the Territory to appoint Mau officials, collect Mau taxes, and in fact, to set up a new form of government."I A Court warrant was issued

\section{Parliamentary Paper A4, 1934, p.3.}


for a search of Nelson's residence "Tuaefu" near Apia, and a number of incriminating documents were found there. Included amongst these documents" were a "Constitution of the Mau of Samoa" and a "Budget" in Nelson's handwriting. Nelson was arrested and after a 32 day trial found guilty and sentenced to eight months' imprisonment and ten years' exile. On 8 March 1934, he was sent to New Zealand where his sentence was reduced, on appeal, to three weeks' imprisonment and ten years' exile. A number of the other Mau leaders were arrested, tried, found guilty, and sentenced to varying terms of imprisonment for their participation in a seditious organisation.

Again the Mau lapsed into a passive state; Fonos were held and letters containing many "points" were sent to the Administrator, but there was little active political unrest. "Since that event /Ehe departure of Nelson] there has been no trouble or difficulty of any kind whatever, the Mau is moribund, the great bulk of the Samoans go about their daily occupations unconcerned with it, and practical administration is in no way affected." ${ }^{2}$ Sir Herbert Hart retired on 25 July 1935 and was succeeded as Acting Administrator by Mr. A.C. Turnbull, Secretary to the Administration and Deputy Administrator.

1 The documents were presented as exhibits in Police $v$. 0.F. Nelson, and copies are on File I.T.1/23/20.

2 Parliamentary Paper A4, 1935, p.13. 
The next important event in Samoan history took place not in the Territory but in New Zealand. In the elections of November 1935 the Labour Party became the Government of New Zealand. The leader of the Party in opposition for many years, Mr. H.E. Holland, had always taken an interest in Samoa and had been the New Zealand politician most sympathetic to the Mau. Nelson and his Auckland supporters had carefully cultivated the goodwill of the Labour Party. This interest was repaid on the day following the election when the new Prime Minister, Savage, is reported to have rung Nelson, now residing in Auckland, with a promise to change the order of things in Samoa. The first concrete evidence of the new Government's determination to carry out its expressed intentions towards Samoa was the announcement in April 1936 that a Ministerial Goodwill Mission would shortly visit the Territory and that facilities would be afforded for Nelson's return to Samoa.

The Goodwill Delegation (Hon. F. Langstone, Minister of Lands, and Mr. J. O'Brien, M.P.) arrived in Apia on 23 June 1936. They found that -

"... notwithstanding the fact that there had been a change to a Labour Government in New Zealand ... there was still, in the mind of the average Samoan, a distinct element of doubt that anything would be done to erase the sources of old grievances and to remedy existing wrongs .... Soon after our arrival in Samoa, it became apparent to us that, strongly 
entrenched in the Samoan mind, was the conviction that the officers of the Administration were responsible for all the troubles of the past, in that they had sent to the Government of the day false reports which had been acted upon in ignorance of the true position, and which had resulted in the ruthless elimination of age-long customs and traditions dear to the Samoan mind. So strong was this feeling that, in all earnestness and sincerity, the representatives of the Mau movement advocated, as a first step to the fulfillment of the delegation's objective, the removal of all the New Zealand officials ... As another indication of the attitude of the Mau, we have to record that, at many of the Native receptions given in our honour, we had to listen to songs relative to the shooting of Tamasese and other Natives, the exile of Taisi (O.F. Nelson), while others recorded their disapproval of the administration of Samoa by the New Zealand Government." 1 jume 1936

On the day after their arrival,/ the Delegation announced the repeal of the declaration of the Mau as a seditious organisation and of regulations (which had been dormant) containing power to restrict the movement of Samoans within the Territory. In the course of further meetings over the next month - in the last of which Nelson was able to participate as the spokesman of the Samoans - the following charges were also announced or made effective -

(1) Arrears of personal and medical taxes owing on 1 April 1929 (when the taxes were suspended) were written off. The Ordinance empowering the levy of these taxes was repealed on 23 December 1936.

(2) The Samoan Offenders Ordinance 1922, under which the Administrator was empowered to "banish" individuals from their villages and to forbid the use of matai titles, was also repealed on 23 December.

1 Report of the Goodwill Delegation to the Prime Minister of New Zealand, File I.T.I/65/-, Visit of Parliamentary Representatives - Goodwill Delegation. 
(3) The Samoan membership of the Legislative Council, set at two in 1930, was increased to four.

(4) Tuimalealiifano, the highest ranking Mau chief and a former Fautua, was restored to that office.

(5) A Finance Committee was established, consisting of three Samoans and one European. The Committee was to discuss the estimates with the Administrator and two officials. The Legislative Council was also to discuss the estimates, which were to be published in Samoan.

(6) A re-election of the Fono of Faipule was to be held in October.

(7) The appointment of a Samoan assistant or associate, who was in future to sit with and advise Judges or Commissioners of the High Court at Apia in cases involving Samoans.

(8) An extension of health and education services was announced.

(9) The President of the Mau, Faumuina Fiamē, was offered the position of Supervisor of Native Police, which he accepted. (He was succeeded as President of the Mau by Tupua Tamasese, a younger brother of the Tamasese killed on "Black Saturday" 1929.)

of these changes, the 1936 Annual Report recorded "... those which have had greatest effect upon Native affairs have been the abandonment of a repressive policy for one of political freedom of expression, and the redistribution of 195 appointments of Faipule and Pulenu'u in which the Mau have participated.

The Mau is continuing as an organisation which seems partly political and partly to supply a psychological need in the present condition of Samoan life. It provides a means for the exercise of ceremonial and social procedures, and its ambitions for self-government make it attractive to the independent Samoan natives. It formulates requests for submission to the Administration or to the Mandatory, but does not now hinder or oppose the functioning of Government. Non co-operation with the Administration has ceased."I 
The years between the Goodwill visit and the outbreak of World War II saw the supporters of the Mau come to dominate the institutions of Government so completely that there was little reason for its continued existence as an instrument of political agitation. (Particularly was this so after April 1938 when Tamasese was appointed a Fautua.) During the early years of this period Turnbull, still Acting Administrator, assisted by a Secretary of Native Affairs of long Samoan experience in C.G.R. McKay, maintained a sometimes uneasy alliance with Nelson. The Administration's policy was almost one of "peace at any price". Witheford's judgement ${ }^{l}$ "that the improved relations with the Samoans were the result of a more conciliatory attitude on the part of the Labour Government rather than the introduction of any long range policy" is undoubtedly sound.

An example of the tactics of both Administration and Mau is shown in this extract from a report of 13 October 1936 by the Secretary of Native Affairs (C.G.R. McKay) concerning elections to the new Fono of Faipule -

"Faipule Alipia on 2nd instant said, 'If any Faipule are allowed other than the 39 we approve, relations between the Samoans and New Zealand may be broken again, and you, the Acting Administrator would be the cause of it.' Mr. Nelson phoned me on 4 th instant and said that if the 39 as proposed by the Samoans were not adhered to there would be very serious trouble indeed.

1 Witheford, H. Samoa, The War and Trusteeship (Typescript, New Zealand War Histories Narrative), Wellington, $1951, p .17$. 
During the preceding week 27 of the old Faipule had amicably accepted the request of the new Faipule that they should retire. On the 5th instant, three others were persuaded by the Administrator and the Secretary of Native Affairs to do so, leaving the Fono constituted of the 39 sponsored by the Mau. Apart from this incident wherein one feels that justice has been sacrificed in the interests of peace, matters have proceeded smoothly and fairly reasonably."I

The new dominance of the Mau inspired a typically Samoan reaction. Just as the Mau had grown in opposition to the "Malo" so now a "Mau Fou" (New Mau) came into being, particularly in the district of Vaimauga East (near Apia) which had been deprived of its Faipule representation in the redistribution of seats by the Mau. (See Chapter V) There were also several minor incidents inspired by the widespread Malietoa family after Malietoa Tanumafili resigned from the Legislative Council following pressure from the Mau. However, by the end of 1938 many of the difficulties associated with the political changes instituted following the visit of the Goodwill Mission had been settled and Turnbull was able to report -

"that there has not been so much co-operation by the Samoans in the administration of the Territory, or such goodwill shown towards the Administration for many years past. If we can carry on quietly and make progressive improvements it is anticipated that the good conditions prevailing will continue." 2

1 Secretary of Native Affairs to Acting Administrator. Copy on I.T.88/3/ - Natives - Fono of Falpules; Interim Reports of Native Affairs by Administrator.

2 Acting Administrator to Minister, 12 December 1938, on I.T. $88 / 3 /=$, op. cit. 
Throughout the early war years, Samoan politics continued without any untoward incident. The main preoccupation of the Fono of Faipule was with questions concerning their own status and their tenure of office, and also that of the numerous other Samoan officials. However, by 1944, dissatisfaction was apparent. In an address of welcome delivered by Fonoti (a younger progressive Faipule) on the occasion of the visit to Western Samoa of Sir Cyril Newall, Governor-General of New Zealand, the grievances of the Samoans were recited. After commenting on the increase in population under New Zealand rule, Fonoti went on -

"Unfortunately social, political and economic progress has not during this period, advanced sufficient to take care of this large increase in population ... one of the main complaints of the Samoans under the present administration is that they are practically denied any effective participation in the administrative and financial control of the territory, and have no power to co-operate in decisions on finance and other matters which closely affect the Samoan people ... The terms of the Mandate have imposed on New Zealand the solemn duty of educating the Samoans to self-government and the terms of the Atlantic Charter express the same aim for the small nations of the world. 31 years have passed since New Zealand took over Western Samoa and we are appreciably no nearer this goal." I

Quoted by Witheford, op. cit., pp.47, 48. 
From this date on the political energies of the Samoan leaders - stimulated by the principles of the Atlantic Charter - were channelled towards demands for "self-government". The Prime Minister, Fraser, who visited Samoa in December 1944, was confronted with a number of specific demands and also "the wish of the Samoans ... that the Government of Samoa be handed over to the Samoans after the war." I

This is a convenient point to halt this long prefatory narrative. There is no doubt that after Fraser's visit "it becomes a matter of immediate Ministerial concern that New Zealand policy in Samoa should win the approval of world opinion." ${ }^{2}$ In this context, New Zealand policy could be directed to no other aim than Samoan self-government, and the history of Western Samoa between 1945 and the present day is the history of a transition through Trusteeship to promised independence. In the period with which the present study is concerned, self-government was an ultimate objective of New Zealand policy (as it was with all colonial powers) but it was an objective that could hardly be realised within the foreseeable future; Administration was more concerned with the prerequisites to selfgovernment - the improvement of standards in health,

\footnotetext{
1 Ibid., p.50. 
education and economic conditions. Since 1945 the emphasis has shifted to political development on the national level; rather as an afterthought it has been argued that social and economic development would follow. Looking back from the threshhold of Samoan independence it is necessary to remember all the time that during the Mandate period the administration of Western Samoa, as of other colonial territories, was "based on an implicit assumption that in some form, European authority over the colonial territories ... will continue for an indefinite period." 1

1 Hodkin, T. Nationalism in Colonial Africa, London, $1956, \mathrm{p} .9$ 


\section{THE FONO OF FAIPULE}

The aim of the Administration's political policy throughout the Mandate period was "Samoan self-government". By this was meant not the integration of all sections of the community into a united and independent state of Western Samoa but delegation to the Samoans of as great a measure of governmental authority as was considered feasible at any particular time. (The German policy of maintaining a rigid dichotomy between the interests and institutions of persons of Furopean status and of the Samoans was continued, and, in fact stimulated by the New Zealand interpretation of the Mandate. $)^{1}$

The most important instrument of this policy throughout the period was the Fono of Faipule. The role of the Fono during the German period as a gathering of officials with purely advisory functions has already been described. ${ }^{2}$ The Fono continued with similar functions during the Military Administration, 1914-20. Col Tate, reporting on 3 september 1919 soon after his arrival, wrote -

"Some little time ago I appointed certain chiefs to fill the vacancies caused by the influenza epidemic among the Faipules. Faipules are the highest grade of Native officials, and rank [second] only to the Fautuas (my Native Advisers); they constitute the Council, or Native Parliament, and are drawn from all parts of Samoa, so that they represent all portions of the country. They meet once a year and on that occasion their functions may be regarded as of a semi-legislative character, al though they are not empowered to actually make any law. During the year they have certain jurisdiction in

${ }^{1}$ See p.40 above

${ }^{2}$ See p.28 above 
the district from which they are drawn, and do a good deal of useful work in affecting reconciliation in quarrels and supervising the performance of duties by others.

The meeting, or Fono of the Faipules, was fixed for the 10th September, and this being the first meeting after the cessation of hostilities, I thought it desirable to mark a new era by opening it with more formality than usual. Accordingly I had a Guard of Honour paraded for the occasion.

On the following day I received and considered the questions that they had raised and the ir opinions on the subjects that I had laid before them for their consideration.

... The principle that the Faipules should be appointed by the Government was established, and this is most necessary because only appointments so made can give them that independence which is so necessary to produce useful work for them. The officials who are elected by the people as a whole are the Pulenu'us or Mayors, of the towns or villages, and no further extension of elective representation is yet desirable. The Pulenu'us are elected by the people and from them the various grades of officials are normally chosen, the Faamasinos (Judges), the Komisi (Iand Commissioners), and finally the Faipules, so that al though the Faipules are persons of Government nomination and appointment they come originally from the Pulenu'us elected by the people." 1

At the Fono of the following year, Tate found a resurgence of the independent spirit which the Faipule had attempted to show under German rule.

"After your departure I met the Faipule at their request on Thursday and the business continued until Friday. I found them somewhat out of hand. They had been too long in Mulinu'u occupied in hatching propositions which they are not competent to discuss." 2

Again in 1921 -

"There is, and will be, a considerable amount of straining by the Faipules for the power to make 1 aws, and they are quite incompetent to make laws. My view of their

${ }^{1}$ Administrator to Governor-General - extract on File I.T.88/3

(Fono of Faipule - Interim Report of Native Affairs by Administrator)

2 Administrator to Minister of External Affairs, 13 March 1920, ibid. 
function is to help me in making laws which affect the Samoan people solely, and when we arrive at anything I have to get it through the Legislative Council as an ordinance. They also strain for the power of making appointments to such positions as those of Faamasino, Komisi and Pulenu'u and also to their own ranks as Faipules. The straining is really for the object of increasing their own power which would be improperly used very frequently ..."

Tate had already had occasion to remind the Faipules of their status and of their dependence on the Administrator for their privileges and authority. In a peech at Mulinu'u of 29 December 1920 he referred to a written statement spoken from by an orator at Faleapuna during the Administrator's recent malaga. The statement had contained the sentence "You must know that you are ruling samoa by the authority of the Samoans."

"Let the re be no misunderstanding about the system of Government," said Tate. "I am not ruling Samoa by the authority of the Samoans. The Allied Nations which won the war gave the control of Samoa to New Zealand under King George of Great Britain and I am governing for New Zealand. My authority comes from the Government of New Zealand and not from the Samoans .... I am the supreme authority in Samoa and upon me the responsibility of governing rests. I am the father of Samoa - the Fautuas and Faipules and people of Samoa are my children. The Fautuas are my Samo an advisers and they get their authority from me. Their duty is to assist me in making laws for the Samoans. They do not make laws, I make them with their assistance. The Faipules do not govern the country - I govern the country ...

The Faipules met last March and I shall call them together again soon and I will get their assistance in making some laws which are in contemplation, and I will discuss with them matters of importance to the 
Samoan people. But it must not be supposed that they govern the country because they do not." 1

During 1921 Tate agreed to hold Fonos twice yearly, in June and December. For the December Fono of 1921 he introduced a new procedure. Formerly the Administrator had merely attended at Mulinu'u to give his decisions upon the Fono's requests and grievances and to present for the Fono's consideration the points upon which he required their views. In future the Faipule were to assemble the day before the official opening and to discuss the points which they wished to bring forward; on the next day the Administrator was to attend, deliver his speech and summarise the matters on which he desired their views; on the third day the Administrator was to meet the Fono in discussion of the points raised by both parties. In this way Tate hoped that the decisions of the Fono would be reached only when the Faipule were in possession of all the relevant information.

The next Fono was held between 27 April and 5 May 1922 for the purpose of discussing the Samoa Act 1921, known by the Samoans as the "Faavae" - "the Foundation". Apparently the only objection of the Faipule to the new Act was that "their names should be in the Faavae"; they desired some recognition of their status. At this Fono Tate delivered an outspoken attack on the "white and half-caste residents ... outsiders ... traders who pretend to be your friends who make al l the ir money out of you." 
Tate's report on the last business session (14-20

December 1922) of the Fono during his administration is worth quoting at length -

"It is possible that they [the Faipule] may desire to discuss matters concerning Samoa generally while I confine them to matters which concern the Samoan natives only or chiefly. That they should be confined to this is in my opinion a matter ofimportance. In many respects they are only children in development, and my hope that there should be some day a 'Parliament' for the Samoan people would never be realised if they were allowed now any jurisdiction on any such matters as Finance, Customs and so on. I think they can be developed into a Parliament if they are trained in considering matters which concern the Samoan native and are restrained in dabbling in things that are too big for them. On the other hand, information should be freely given on the variety of subjects likely to be advanced - if information were denied they would get misinf ormation from our unfriends.

... Legislation is vested in the Legislative Council and the Faipule have no power of legislation whatever. I think however it is useful (when possible and without derogation of any right to legislate for the Samoans independent of the Faipules) to discuss a draft bill with the Faipule and consider it clause by clause so that when I take it before the Legislative Council I am aware of the native view of the subject. This Bill [the Dog Registration Ordinance] will be taken before the Legislative Council at an early date and I have no doubt it will be passed into law without further alteration." 1

With the arrival of Major-General Richardson as Administrator, official policy towards the Fono of Faipule took a decided change. By the Samoa Amendment Act $1923^{2}$ the Fono was given statutory recognition in accordance with the wishes of the Faipule. Section 4 of the Act read -

"(1) The Administrator may from time to time, by Warrant under his hand and the Public Seal of Western Samoa, appoint such number of Samoans as he thinks fit to be Faipules. No person shall be appointed as a Faipule under this section who is not qualified, in accordance

1 Administrator to Minister, undated, ibid

21923 , No. 24 
with existing Samoan usage and custom, to occupy the position of Faipule in any Council or body having advisory functions.

(2) The appointment of any person as a Faipule (whether such appointment has been made before or after the commencement of this Act) may be at any time revoked by the Administrator for any cause that he deems sufficient.

(3) All persons for the time being holding appointments as Faipules shall together constit ute a Council of Advisers to the Administrator under the name of the Fono of Faipule, and shall meet at such times and places as the Administrator from time to time appoints in that behalf.

(4) The Administrator shall preside at any meeting of the Fono of Faipule at which he is present.

(5) It shall be the function of the Fono of Faipules to consider such matters relative to the welfare of the Samoan people as of their own initiative they think proper or as may be submitted to them by the Administrator, and to express their opinions and make their recommendations to the Administrator."

One of the main grievances of the Mau heard before the 1927 Royal Commission concerned the method of appointment of Faipule. The 1923 Act authorised the Administrator to appoint as Faipule only those Samoans "qualified in accordance with existing Samoan usage and custom to occupy the posi tion of Faipule." In practice this did not mean very much. The position of Faipule was an alien introduction and there could really be no "Samogn usage and custom" by which a Samoan could qualify for appointment. However it was acknowledged even by the critics of the method of appointment of Faipule befare the Royal Commission that if Faipule were selected by the matai of their districts to act purely in an advisory capacity that would be acceptable; it was implied on the part of both 
Administration and critics that the districts would be the traditional political districts. ${ }^{1}$ According to the evidence of the Rev. F.G. Lewis (Secretary of Native Affairs) before the Commission ${ }^{2}$ the Faipule as at 1927 had been appointed as follows -

"Aiono and Toelupe : These are the only two Faipule now living who were appointed under the German regime and by the method indicated above as used by Governor solf [i.e. nomination by the assembled Faipule to fill vacancies; the appointment resting with Governor alone]. Toelupe was one of the original 13, and has been the Faipule of his district for more than 28 years, through changing systems and changes of government.

Tainau and Malupo : Under British military occupation the same method was continued, the Administrator accepting two lines of advice - (1) the highest suitable chief available in the district; (2) the promotion of officials already serving the Government - Malupo appointed 1916; Tainau 1918. Malupo was pulenu'u from 1905, Tainau from 1917.

The epidemic of 1918 carried away all Faipules except the above-mentioned four.

1919 and 1920 - The Administrator appointed a great number of Faipules on the recommendation of the Secretary for Native Affairs, who had been in conference with his Native advisers. Of the present Fono the following were thus appointed:

Sagapolutele, Tuatagaloa, Sal anoa, Malaitai, Unasa, Fonoti, Ama, Logo, Va'ai, Mataafa, Manai, Seiuli, Tuisal ega, Seinafo, Tuilaepa, Tapusoa, Leilua - seventeen in all. There was complete satisfaction with these appointments, no complaint being heard of prior to the 15th October 1927.

1923-27 (the present Administrator's regime) - Ten appointments have been made, some being to fill vacancies and others additional appointments, the appointments being by the Administrator with the approval of Ali'i and Faipule of the districts concerned.

${ }^{1}$ See evidence of E.W. Gurr, Roval Commission Report, op cit ibid, p.265 
Pei and Suisala, 1923; Asi Mama and Sua Latu, 1924; Sui Mui, 1925; Fuamatu and Seumanatafa, 1926; Tafua, Tupuola and Sua Soloi, 1927. In the case of Tafua the approval is certified by signatures of the Ali'i and Faipule. Sua Soloi had been Acting Faipule for about 2 years during the illness of the late Faipule Lemalu. Two months after his permanent appointment the Lefaga District expressed to the Administrator, when on malaga, their satisfaction at the appointment.

Pei, Suisala, Sua Latu, Sua Mui, Seumanatafa. These five Faipules from Savai'i were appointed to fill vacancies caused by death or dismissal, and were chosen for their high titles and previous service. After consultation of the Resident Commissioner of Savai'i with the Ali' $i$ and Faipule of the Districts concerned he recommended the appointments, and the Administrator approved. In no case has there been any complaint by the people over appointments till now."

Richardson several times informed the Minister of the policy adopted by him in appointing Faipule. Thus in a memorandum of 14 January 1927 he said -

"In order that you may be fully conversant with the method of appointing Faipules, a matter to which the Committee of agitators recentiy took exception, I wish to inform you that although the Act provides for Faipules being appointed by me, the method adopted in practice is as follows:-

When a vacancy occurs I inform the Ali' $i$ and Faipule (Chiefs) of the District concerned that they are to nominate a Faipule, and if they cannot agree amongst themselves they are to submit 2 or 3 names.

The Chiefs then hold meetings and discuss the matter, and often have heated arguments over the selection, but it is a Samoan custom to argue until all agree or to say that they agree to a decision, so that when a Chief is finally nominated he is selected and approved by the whole District.

I have not yet had a case of two or more names being submitted, the Chiefs of the District have always managed to agree, so that my appointment of a Faipule to suit myself as suggested by the Committee is entirely erroneous." 
There is no reason to doubt that this extract sets out the procedure in fact adopted by Richardson in making appointments to the Fono. However, according to the evidence of Lewis quoted previously only ten Faipule were appointed by Richardson; the other 24 had been appointed for life by earlier Administrators. In any case the main criticism was directed not so much at the method of appointment alone but at the functions assigned by Richardson to persons appointed in this manner.

During Tate's administration, the duties of a Faipule were set out in a "Memorandum Concerning the Duties of Samoan Government officials - as discussed and agreed to at the Fono of Faipules, December 1921."1

"1. The Faipule Peritania is an official of the Administrator, and will receive his orders from the Administrator. He is the representative of his district on the Council of Faipules. Special matters only concerning the Faipules will be signed by the Administrator; all other matters must go through the secretary of Native Affairs.

2. He will go to all Fonos or meetings at Mulinu'u which shall be arranged by the Administrator. At these Fonos the Faipule Peritania will discuss with the Administrator matters brought before the $m$ by the Administrator, and matters brought before the Fonos by one or more of themselves; and then they will give the Administrator their opinion on such matters for the assistance of the Administrator in the good government of the Samoans. The Governor will give his consent or disapproval of the matters, and his decision will be published as 1 aw for the Samoan people.

3. Should anyone be very ill or find very serious hindrances preventing his attendance, then he shall write to the Administrator and explain the reason. That letter shall be produced at the Fono in question. 
4. The Faipule Peritania shall carefully take into consideration all matters placed before the Fono. They must declare the real meaning of their opinion, and not attempt to support argument swayed by family consideration ( $\left.\mathrm{fa}^{\prime} \mathrm{a}-\mathrm{le}-\mathrm{aiga}\right)$, or by customary errors ( $\mathrm{fa}^{\prime} \mathrm{a}$-Samoa), as was formerly the case. They must watch over the interests of every one, and not favour any family or person, whether friend or opponent. The faithful Faipule is known by his succeeding in such matters.

5. The Faipule must always act as an example to other officials and to the people. He must endeavour to increase good will and concord amongst all people, and use all his influence for the observance of the laws and the keeping of peace and order. Should he discover any difficulty arising or any improper actions, let him report it quickly to the Administrator through the Resident Commissioner of his district or the secretary of Native Affairs.

6. The Government will forward to the Faipule all new laws, tulafono, etc., for distribution to all officials in his district. These he will send around by his Leoleo, including the distribution to officials only of the Savali.

7. He will hold quarterly meetings at his village of all Government officials in his district to explain new laws etc. All matters of interest which arise he will bring under the notice of the Government.

8. When any Faipule visits Apia he must not forget to call on the Secretary of Native Affairs to find out whether there are any new laws or instructions from the Government which he should receive.

9. The Faipule should remember that the Government desires that the Samoans should do their own work, and not become dependent upon people brought in from outside. Therefore he will act as the representative of the Government in assisting the provision of labour for works.

10. Let not any Faipule go on a journey or leave his district without advising the secretary of Native Affairs or the Resident Commissioner of his district."

It is clearly envisaged in this memorandum - which was never officially rescinded - that the Faipule were advisers 
to the Administrator on Samoan matters and one of the channels of communication between the people in the villages and the Administration in Apia. They certainly had no executive functions; a Faipule was "to use all his influence." While the Faipule remained "an official of the Administrator" the Samoan communities acknowledged the position as one of some status but of little effectiveness. Gradually the Faipules attempted to build up the significance of their position by usurping the functions of other officials, particularly the Faamasino (or district judges) and by reporting to the Administrator matters which would in the normal course have been settled within the traditional framework. A practice was established whereby the Administrator referred these matters to a committee of Faipule for report; in many instances the committee recommended the punishment of local "banishment" which was one of the main issues before the 1927 Commission.

The desire of the Faipules to build up their status and power was encouraged by the Administration under Richardson. Thus in his annual report for $1923 / 24$ he said:

"The legislation enacted by the New Zealand Parliament last session whereby the Fono (Council) of Faipules was legally constituted to deal with Native matters has given satisfaction to the Natives generally and has inspired the Faipules with confidence that under the present Constitution no legislation affecting the welfare of the Samoan race will be introduced without first obtaining the wishes of the people and the advice of their representatives, the Faipules.

In the past the Samoans have not taken much interest in the work of the Faipule Fono, but now, through its 
newly acquired legal standing and the publication of its proceedings in the Native press, they are gradually realising its value as a national institution where the opinions of the people can be made known and where their interests will be safeguarded." 1

During 1924, Richardson strongly urged that power be given to the Administrator to make "Native Regulations with the advice and consent of the Fono of Faipule." Writing to the Minister on 5 February 1924 he enclosed a draft "Native Regulations Empowering Order (Samoa) 1924" and said -

"It was probably not realised when this Act [the Samoa Act 1921] was passed that in addition to the ordinary regulations it would be necessary to regulate the customs and social life of a large Native population in a primitive stage of development, and that as in Crown Colonies provisions should be made for Native Regulations to be issued locally.

There are no Native Regulations in Samoa, in consequence of which, difficulties in administration are constantly occurring. These difficulties would be removed if I had the power to make Native Regulations: all such regulations to be discussed and framed in consul tation with the Faipules and Secretary for Native Affairs, who would do their part thoroughly and conscientiously in the best interests of the true development of the Natives.

I now wish to make certain regulations re Titles, Limiting Powers of Chiefs, Sanitation of Villages, Education of Native Children, Maintenance of Boads by Natives, Cleaning of Plantations, Compulsory planting, Compulsory Medical Treatment for Certain Diseases, Methods of Making Complaints, Duties of Native Officials and very many other matters.

The existing machinery of drafting every regulation for submission to the Governor-General in Council is too slow, and unsuitable so far as Native Regulations are concerned. Not only is it wrong in principal [sic] to allow the Legislative Council to make Native Regulations, but the Faipules themselves will object to any regulations the $y$ have agreed to in consultation with me, being subsequently referred to a less competent body regarding Native matters, viz: the local Legislative 
Council. Furthermore, it will give the Faipules great pleasure to know that they practically have the power - subject to my approval - to make Regulations for controlling the life and customs of their own people." 1

In reply, the Minister (F.H.D. Bell), after consulting the Crown Law office, said -

"I have carefully considered your proposals and find that there is no statutory authority to enable the Governor-General in Council to confer power upon you, with the advice and consent of the Faipules, to make regulations having the force of law in Samoa, nor do I think it would be wise or expedient to ask Parliament to grant legislative authority to make such regulations in addition to the authorities already existing in the Samoa Act."

Richardson raised the matter again in a memorandum of 19 June 1924 requesting a number of amendments to the Samoa Act, including one repeating the provisions of the earlier draft Order in Council -

"The Natives now make regulations for local selfgovernment in their villages. The present amenament not only legalises this custom but will control it in such a matter as to give the Administrator, in conjunction with the Faipules, power to make regulations which will have a far reaching and most beneficial effect upon the whole of the Native race.

I have informed the elected Members that I proposed asking for this Amendment and they have no objection. It may be said that the same powers could be obtained by a local Ordinance, but if the work of the Faipule Fono is discussed in the Legislative Council and the Faipules get the idea that all regulations they make on purely Native matters must be approved by the Council, the prestige of the Administrator will suffer.

The Council (or Fono) of Faipules has been legalised by Parliament, but its duties and functions are limited to considering and recommending to the Administrator. I am confident we should go one step further and give the Faipules more responsible duties and legalise decisions of their Council subject to the Administrator's approval.

${ }^{1}$ Administrator to Minister, File I.T. 67/34 (Legislation: Native Regulations Empowering Order 1924; Native Regulations 1938) 
During the last Fono, Regulations were drafted by me in conjunction with the Faipules on many matters of importance, but I cannot enforce them unless the question is discussed in the Legislative Council or the Act is amended." 1

\section{Sir Francis Bell in reply said -}

"I regret that I am unable to see my way to accept the proposed amendment to authorise the Administrator with the advice and consent of the Fono of Faipules, to make Native Regulations. I have already expressed my opinion on this matter in my memorandum to you of 10th March last. I am in entire sympathy with your desire to take full advantage of the machinery of the Fono of Faipules and to induce the latter to take $a$ greater and more responsible interest in all matters affecting the government and well-being of the ir people. I think, however, that the difficulties that you fear may arise if the decisions of the Fono in matters relating exclusively to Native affairs are submitted for the criticism and approval of the Samoan Legislative Council can be removed by always forwarding such Native Regulations for ratification by the Governor-General of the Dominion of New Zealand in Council. I shall always be prepared to accept any Native Regulations which you as Administrator forward to me in this behalf and to recommend His Excellency the Governor-General in Council to approve them. I think this procedure should be acceptable to the Faipules as adding to the dignity and importance of the deliberations of their Fonos." 2

Richardson, on 18 August, commented -

"... this will be equally satisfactory to the proposal I previously submitted for giving myself authority to make such regulations. All I desire is to be able to make Native Regulations and to avoid having such regulations submitted and discussed in the Legislative Council, for reasons which I have submitted to you in private correspondence." 3

In due course Richardson submitted draft Native Regulations incorporating "a number of Native Regulations passed [during the last Fono of Faipules] for the purpose of controlling Native

${ }^{1}$ Ibid

2 Ibid

3 Ibid 
life in villages outside Apia." These regulations - the Native

Regulations (Samoa) Order $1925^{1}$-established a number of

District Councils (see Chapter VII); empowered them to issue

by-laws "for the good rule and government of villages"; provided for the establishment of village committees, and laid down rules regulating a number of everyday activities of Samoan life.

The 1925 Regulations insofar as they established a system of local government are discussed in a later chapter; in this chapter we are concerned only with their effect on the position of the Faipule. In general, this was unfortunate. First, Richardson seems, unaccountably, to have persisted in his view that the Fono should be a lawmaking body. In the Annual Report for $1924 / 25$, the following statement appears -

"The Council of Faipules has most earnestly responded to the increased powers with which it has been vested viz: to work with its President, the Administrator, in the making of Native Regulations. The granting to the leaders of the Native race these new legislative powers in place of purely advisory functions which they hitherto were limited has been a great step in advance, and has made itself felt for the good of the Natives in every village in Samoa.

It is in this Council of Faipules, which meets twice annually, that the Administrator is able to bring his influence to bear on every district; to ascertain the views and needs of the Natives, and, in conjunction with their leaders, to discuss the best means of helping them." ${ }^{2}$

The statement that the Fono had been granted "new legislative powers in place of purely advisory functions" was, of course, quite incorrect; it does, however, indicate Richardson's determination to build up the status of the Fono and to

1N.Z. Gazette No. 23, 2 April 1925

Parliamentary Paper A4 - 1925 p.8 
use the Faipule not only as officials in the districts but collectively as a national representative body. When crossexamined before the Royal Commission, Richardson persisted in his view that the Fono should be a law-making body and did not deny that he had allowed the Samoans to gain this impression. With reference to a volume entitled "Laws of Samoa" - "all these regulations and exhortations, affecting Natives,"-the following exchange took place between Baxter (Counsel for the Mau) and the Administrator ${ }^{-}$

Baxter: Was this other phrase "Approved of or assented to by the Administrator" in accordance with the wishes of the Fono of Faipule?

Richardson: That is how the Samoans would read it. That is how they ought to be able to read everything. They appreciate being able to regard the Administrator as the man who controls everything.

Baxter: Do you not think that having been called "Laws of Samoa" and having been approved of by Your Excellency in accordance with the wishes of the Fono, that it was quite likely that the Samoans would get the idea that the Fono was legislating and passing laws?

Richardson: The Samoans would be delighted to think that it was so. The Samoans would love to feel that their own representatives actually made the laws, and if they did get those ideas it would not make any difference.

Baxter: It would be quite reasonable for the samoans to consider these regulations and legislation on the part of the Fono?

Richardson: Quite reasonable.

Baxter:

On p.1, 7(3) [of the "Laws of Western Samoa"], Your Excellency, you notice the word used there

${ }^{1}$ Roval Commission Report, op cit p.380 
is "law". That would convey the impression that they have power to legislate, would it not?

Richardson: Yes; and I would be very pleased if it did convey that impression. The Faipules know that laws must be signed by the Governor-General in Council. I want to uphold the prestige of the Faipules as much as possible."

The judgement of the Commission on the "Book of Laws" was that "Technically, of course, it was a mistake to include these experimental and advisory resolutions amongst the enforceable and binding laws. In our opinion, no harm was done by the adoption of this course." 1 Viewed by itself, the incident of the "Book of Laws" was probably only a "technical mistake"; as part of the Administrator's policy of recognising only the Fono of Faipule as representative of Samoan opinion the incident is of more significance. The varying method and tenure of appointment of the Faipules and their position as government officials - always emphasised by Tate - made the Fono unsuitable as an embryo "Parliament" for the Samoan people. In its original conception, the Faipules were advisers to the Administrator and district officials with functions primarily of a public relations nature. Under Richardson, the Administration was on the one hand attempting to give the oddly assorted body of Faipules - many of whom were appointed for life - "authority to speak for Samoa"; on the other, the Faipules were increasingly being given executive powers in the districts and villages. On the surface, Richardson's desire to build up the 
prestige of the Faipule and to work through them in all matters of Samoan administration appears to be an application of the classic principle of "indirect rule". Unfortunately Samoan society did not (and does not) possess the essential features necessary to make "indirect rule" through individuals a working system of Native administration: there are no undisputed hereditary rulers, the only institution of any permanence being the Alii and Faipule of each village; the main political divisions are based on family allegiances rather than geographical areas; and group decisions on all levels are reached by discussion and compromise rather than chiefly fiat. It is therefore not difficult to understand why the status of the Fono, while it remained an assembly of government officials, did not stand high in Samoan eyes. Richardson's policy reached its logical outcome in his refusal to negotiate with the Citizens Committee on native matters and his insistence that all grievances be raised through the usual channels, i.e. through the district councils and the Secretary of Native Affairs, for discussion in the Fono. As Samoa became clearly divided into two camps - the "Malo" and the "Mau" - the Fono soon lost the status and prestige which Richards on had tried to build up.

"At the Assembly in February [1928] the ordinary business was suspended and the discussions were confined to considering ways and means to reunite the two parties of Natives and restore the peaceful and prosp erous canditions that existed prior to the European Committee interfering in Native political affairs. During the Fono endeavours were made by invitations to those chiefs 
in the so-called "Mau" Committee to meet the Faipule to become reconciled and discuss matters together for the general welfare of the Samoan people. These chiefs refused, however, to meet either the Faipules or the Administrator, and it is believed that this irreconcilable attitude was due to the fact that they had received instructions not to co-operate in any way with Government officials or with the Government and to continue to oppose constituted authority." 1

There were at this stage three vacancies for Faipules which could not be filled because of the inability of the districts to agree on new appointments.

The Annual Report for 1928/29 recorded that -

"No Fono of Faipules has been held, except to welcome the new Administrator on his arrival in May 1928, but on several occasions fonos of officials have been held in both islands to discuss matters of policy in Native affairs. It is now proposed to suspend the Faipules for the time; the Faamasinos are also to be suspended, as they have been performing no duty recently except in a few cases. European District Officers are now being appointed to perform the duties of the District Councils and the Faipules in the various districts; and it is hoped that this change in system will lead on the one hand to a stronger control of the Native Population, and on the other to a closer touch between the Administrator and the individual Native." 2

In 1929, two representatives of the Samoan race were appointed to the Legislative Council. As a temporary measure until arrangements could be made for the samoans to elect their own representatives, the two Fautua - Malietoa and Mata'afa - were appointed to the Council. The Government was careful to point out that they -

"do not feel that representation on the Legislative Council of the Territory can be regarded as an adequate means of enabling the Samoans to share in their own government, and they have contemplated either the re-

\footnotetext{
1 Parliamentary Paper Aty - 1928, p.5

2 Parliamentary Paper A4 - 1929, p.3
} 
institution of the Fono of Faipules when conditions allow or the substitution of some equally suitable means of associating the Samoans in their government. As the result of a meeting between the Administrator and a generally representative gathering of Natives which took place [between March and July 1930] it seems clear that the Samoans still desire the Fono of Faipules as their representative body, and the Administrator is now formulating a scheme for the revival of this body on lines that will allow of the representation of all sections of the Native race." 1

The Fono was restored in October 1930 under the scheme mentioned above. Members were now to hold office for three years and were to be formally appointed by the Administrator after nomination by the matai of the district. Although the reconstituted body was designed to meet the criticism levelled at the former Fono, almost all the previous Faipule were returned. The explanation is, of course, that the Mau boycotted the new institution and only matai supporting the government participated in the nominations. The term of office of the Faipule appointed in 1930 was shortened to one year in the hope that the Mau would by then have forsaken their attitude of non co-operation. However, the position was little changed in 1931 when nominations were next received and the Fono continued as a temporary and rather inadequate expedient until the visit of the Goodwill Delegation. The functions of the Fono were now purely advisory and the authority which the individual Faipule had gained under Richardson as the Administrator's executive officers in the districts was not restored. 


\section{THE LEGISLATIVE COUNCIL}

Although the interests of the Samoans were paramount under the Mandate, it was quickly apparent that Western Samoa needed other institutions to supplement the Fono of Faipule. It was an administrative necessity to have some body which could make local legislation and the Fono was obviously not an appropriate institution; it was also unthinkable that a British territory should deprive the resident Europeans of a voice, however small, in the affairs of government.

As early as July 1919, Col Tate ${ }^{1}$ had recommended that an Executive Council should be established "on the principles which affect Crown Colonies wi thout Legislative Councils". He suggested "that at first the Council be strengthened by the addition in an advisory capacity of three members representing the commercial and planting interests who might be called upon to sit with the Executive Council when requested." However, the authors of the Samoa Constitution Order - primarily the famous Solicitor-General, Sir John Salmond - provided for a Legislative Council on the Crom Colony model with an official majority of not less than four members and nominated unofficial members not more in number than the official members.

On 30 November 1919, the Administrator, in a telegram to the Governor-General, reported that "if Legislative Councillors are not appointed until the Constitution Order-in-Council comes into force there will be no opportunity of conferring (tvoescript held by Department of Island Territories) 
with them upon many important matters in regard to which decisions must be reached meanwhile". 1

After being authorised by the Minister of External Affairs (Sir James Allen) to get in touch with suitable men, the Administrator reported by telegram on 26 December that he had "approached Nelson and Andrew, merchants, unable to accept. Also Sydall, merchant, and Tattersall, photographer, who accepted. Also Keeling, Manager, Bank of New Zealand, who has referred offer to Head office. Please urge Bank to permit manager to act, financial expert being desirable." In due course the Bank agreed to their Manager acting and the three persons nominated presumably operated as an unofficial advisory council to the Administrator for the few months until the Constitution order came into force. There is no record of the matters on which the "unofficials" were consulted.

The Samoa Constitution Order came into force on 1 April 1920. On 13 April the Department of External Affairs sent the following telegram to the Administrator -

"Pursuant to Constitution Order it is proposed constitute Legislative Council as follows: official members - Chief Justice, Chief Health Officer, Commissioner of Crown Estates now Military Liquidator, Treasurer, Secretary of Native Affairs. Unofficial - Keeling, Sydall, Malietoa, Tui [malealiifano]"

The Administrator replied pointing out that Malietoa and Tuimalealiffano could not be unofficial members because as Fautua they were each in receipt of salary from the Administration. 
Apart from this constitutional objection, Tate claimed that "their ignorance of English would necessitate all proceedings and debates of Council being interpreted. This woul a hamper canduct of business." ${ }^{1}$ He suggested that they might be attached to the Council informally as "advisory representatives of the native race."

Tate suggested that the Chief Health Officer should be deleted from the list of official members suggested by the Department and that three unofficials should be appointed "leaving vacancy for appointment of planter when available." The Department accepted the Administrator's proposal and the first Legislative Council was constituted accordingly.

The function of this first Council was almost exclusively legislative. Before it was superseded by the partly elective Council established under the Samoa Act 1923, the Council passed Ordinances covering the whole field of territorial government. The Council provided no real outlet for criticism of the Administration; the merchants, the most vocal of critics, having refused nomination. Opposition, which was directed primarily at the liquor law, was expressed through "Citizens' Committees" which were formed to make representations to visiting New Zealand Parliamentarians and Ministers. The leading spokesman of the Citizens' Committees was Olaf F. Nelson.

1 "The chief difficulty of finding native members 1 ay in the circumstance that the only ones with the necessary knowledge of Inglish were in the government employ, and would have to resign in order to accept membership of the Council ..." Wight $\mathrm{M}$, The Develooment of The Legislative Council 16061945 London, $1946, \mathrm{p} .74$ 
The complaints of the Citizens' Committees early took on a constitutional form. There were two main grievarces: firstly, opposition to legislation by New Zealand Order in Council and, secondly, agitation for election to be substituted for nomination in the selection of the unofficial members of the Legislative Council. The first of these complaints was directed at the Government's policy of enacting all legislation affecting Samoan affairs by New Zealand Order. Although consistent with New Zeal and's mandatory policy, this action, together with certain remarks by the early Administrators concerning local traders, was not calculated to engender a feeling of mutual trust between the Administration and the fairly close-knit European community. That the Administration was sensitive of this criticism was shown in the first annual report, which contained this passage -

"An impression exists that the Legislative Council has now power; but on the contrary, it is vested with real power, no local legislation being without its concurrence. This is an advance on the German system, under which the legislative government was vested in the Governor, who, although he assembled an Advisory Council for consultation and advice, was independent of his Council, which possessed no actual power." 1

In fact section 46 of the Samoa Act 1921 conferred upon the Administrator, acting with the advice and consent of the Legislative Council, power to make laws (known as ordinances) for the peace, order and good government of the Territory. The Ordinances were not to be repugnant to the Samoa Act or regulations made under it, or to any other Act of the New Zealand 
Parliament or of the United Kingdom Parliament, or any regulations in force in the Territory. This legislative power extended to the imposition of tolls, rates,dues, fees, fines, taxes and other charges.

The more important of the citizens' criticisms was directed at the method of appointment of unofficial members.

As early as 1921, Tate met representative members of the Apia Chamber of Commerce in an attempt to agree upon a workable scheme for elective representation. The Administration was apparently quite willing to accept elective membership, the points at issue concerning the franchise. In some undated notes (about 1920) Tate was uncompromising in his opposition to a proposal for European universal manhood franchise -

"[Many part Europeans] are little removed from the Samoan, and I think they constitute the bulk of the half castes. A large amount of voting power on manhood suffrage would be given to these men, who are in no way qualified to exercise a franchise wisely ... to give the vote to the whole of the Samoans at the present time would, I think, be an absurdity." 1

At the meeting of 25 November 1921, attended by Nelson and C. Roberts - a former Judge of the High Court - agreement was reached that representation should be on the basis of taxation. Consi deration of the details was left until the Taxation Ordinance came into force early in 1922. After further discussion in June and July 1922 between the Administrator, the Chamber of Commerce and the existing Legislative Councillors, the following qualifications were agreed upon -

1File I.T. $1 / 8$ op cit. 
"Every male person shall be entitled to be registered as an elector, and when registered to vote at the election of Elected Members of the Council, who -

(Nationality) 1. (a) Is the son of parents of European descent.

or (b) Is the legitimate son of a father who is a European.

or (c) Is registered as a European under the Samoa Registration of Europeans Regulation 1920.

(Age)

2. Is of the age of 21 years or upwards.

(Residence)

3. Has been continuously resident in Samoa for twelve months.

(Property) 4. Is possessed either of -

(a) Freehold or leasehold property, or both, within Samoa, of the capital value of $£ 200$, upon which he actually pays taxes.

(b) An annual income derived from salary of not less than $\$ 200$ earned in Samoa, upon which he actually pays taxes."

In recommending that German nationals of European status should retain the vote, Tate made the prophetic comment, "Their number is not considerable (about 50) and I think that any influence for evil they might possess is inconsiderable. They have behaved themselves well. Dr Solf is said to have considered his British residents less trouble than his German residents, who appear to have constantly moved the Reichstag: I think we shall find our German residents similarly of less trouble than our British residents." 1

No action was taken before Tate completed his term but the new Administrator (Richardson) soon raised this question - 
"The citizens of Western Samoa are most anxious to be granted direct representation on the Legislative Council as a first step towards self-government. There are many matters which concern the welfare of Samoa now requiring attention but which I would prefer should be dealt with by a Council on which the people concerned are directly represented. For the above reasons I recommend that the necessary legislation to give effect to the wishes of
the local citizens be passed into law at an early date."1

Richardson, a few months later, revised his opinion of

the citizens' anxiety to have elective representation -

"There does not appear to be any local interest at present over the provisions contained in the Samoan Amendment Act [Bill?] for direct representation on the Council, but the matter is urgent as the present system of taxation is, in my opinion, unsatisfactory and should be revised, but revision of taxation is 2 inadvisable until the citizens have direct rights." 2

In August 1923 an amendment to the Samoa Act ${ }^{3}$ increased the number of official members from four to six and provided that unofficial members (not more in number than the official members) "may be either elected members or nominated members or partly elected and partly nominated members as the GovernorGeneral in Council from time to time determines." Previously the unofficials had been appointed by the Governor-General at his pleasure.

Regulations ${ }^{4}$ governing the conduct of the elections were soon made and the results of elections held on 23 January 1924 were -

${ }^{1}$ Parliamentary Paper A4 - 1923, p.2

${ }^{2}$ Administrator to Minister, 30 June 1923. File I.T. $1 / 33$

31923, No.24

(Monthly Dispatch From Administrator)

${ }^{4}$ Samoa Legislative Council (Elective Membership) Order 1923. 


$\begin{array}{llr}\text { Nelson, } & \text { Olaf Frederick } & 97 \\ \text { Westbrook, George Egerton Leigh } & 90 \\ \text { Williams, } & \text { Arthur } & 86 \\ \text { Smyth, } & \text { Alfred George } & 73 \\ \text { Baxter, } & \text { Fred Davies } & 69 \\ \text { Gardiner, } & \text { Cecil } & 45 \\ \text { Loibl, } & \text { Arthur Horndl } & 21 \\ \text { Meredith, } & \text { Samuel Hornd } & 15 \\ \text { Brush } & \text { Bruce Hays } & \underline{13} \\ & & \underline{509} \\ & & \\ & & \\ & & \end{array}$

Nelson, Westbrook and Williams were declared to be ele cted.

The reconstituted Council met on 5 March 1924. The first act of the Council was to receive a congratulatory message from the Governor-General (Lord Jellicoe). An interesting reflection of the official feeling towards the Council and of New Zealand's Samoan policy in general is cantained in the following extract from a private note of $27 \mathrm{Feb}-$ ruary sent by the Secretary of External Affairs (J.D. Gray) to the official Secretary, Government House (A.C. Day). The note concerned the drafting of the Governor-General's message "The occasion is one of importance and also of interest to Samoa because it marks a step in the progress of representative Government which is much in advance of the usual course of events in, say, Crown Colonies. In Samoa we have advanced from a purely nominative Government to a partly nominative and partly elective one in a little over three years, as against the usual period of about ten years in the case of most of the Crown Colonies. I do not see any harm in referring to this advance, because it is one which only affects the European community and is not one, I think, likely to be misunderstood by the native community. Apart from this, there is no other feature that is worthy of special mention in any message of the kind. If we 
draft the message, I am going to suggest to Sir Francis the advisability of making reference to the fact that under the Mandate we are administering the Territory, primarily in the interests of the indigenous population. I think this is a point that should always be stressed although I quite realise that it is not one which is acceptable to the European population." 1

At the first session of the new Legislative Council the Elected Members quickly - after the pattern of most colonial legislatures - attacked the extravagance of Government spending and particularly the salaries bill. In the first Address in Reply read on 12 March 1924 the Elected Members were "decidedly of the opinion that the reductions in the administrative expenses are not sufficiently drastic." 2 The impotence of the previous Legislative Council in financial matters had been one of the main complaints of the early Citizens' Committees; it was also one of the reasons why Nelson and the more important businessmen of Apia refused to serve on the Council. Writing to the Minister on 13 February 1923, Tate had said -

"The Citizens Committee seems to ke grasping for a control of finance which it is never likely to get. It seems unable to appreciate the function of the Legislative Council in regard to finance and seems to imagine that the full financial power of Responsible Government should be within its reach ... They imagine that the Legislative Council is, or should be, similar to a Municipal Council of a small town which makes by-laws and mends roads and effects repairs to the parish pump. The distinction between the Legislative and Administrative functions will be appreciated in Samoa very slowly and I think they base their notions

File I.T. $1 / 8$

Legislative Council Debates, 1924, p.9 
on the performance of the 'Municipality' which existed in the old days before the German Occupation." 1

However, even though the new Council was given the right to discuss the Estimates the Elected Members soon complained of "their minority [vis-a-vis the official members] and their impotency recognised to the extent of their inability to serve the people of the Territory through the medium of the Legislative Council." 2 At the meeting following the Address in Reply just quoted, Richardson laid on the table of the Council a memorandum commenting on the points made by the Elected Members. Concerning the official majority he said -

"The position is that official members are appointed to the Council to represent the interests of all sections of the community and they are free to vote as they wish. There may, however, arise instances where, in the interests of Samoa as a whole they may be required by me to support the Crown, and to vote in favour of a Government measure which the elected members may oppose ... I hope it will not be assumed that, if the official members do all vote in opposition to the Elected Members, that the wishes of the inhabitants of these islands have been disregarded. The Elected Members represent primarily the interests of the European community while the Government Members must include in the ir outlook the interests of the Government in its task imposed by the Mandate of promoting the welfare of the samoan Race, who comprise $95 \%$ of the population, and who are not directly represented on the council. I am held personally responsible by the New Zealand Government for the peace, order and good government of the Natives." 3

Nelson was quick to turn this statement of policy to

\footnotetext{
${ }^{1}$ File I.T. $1 / 23 / 1$ (Citizens Meeting Regarding Prime Minister's Visit, 1922)

Legislative Council Debates, 1925, p.63

ILegislative Council Debates, 1925, p.71 (my italics)
} 
his own purposes. If the Council was not a fully competent legislature because $95 \%$ of the population had no direct representation, then the solution lay in giving the Samoans representation. At the next meeting of the Council Nelson moved the following motion -

"That the Legislative Council recommend to His Excellency the Administrator that steps be taken towards the representation of Samoan Natives in the Council."

Speaking to the motion he said -

"... I am prompted by the feeling that the Legislative Council is not complete without native representation. To say that the Natives have a Parliament and that their views are represented in the Fono of Faipule is a fallacy. The Fono of Faipule deals with matters that are purely native and does not deal with all legislation benefitting the whole Territory. As the native community which, we have been informed, constitutes $95 \%$ of the total population of Samoa they should have representation in the Council by members of their own race and choice. To say that the interests of the natives are sufficiently cared for in the Council by the Administrator and the official Members is another fallacy. No one can express the Samoan opinion as well as the Samoan himself. The idea that natives are unable to grasp the meaning of the questions of moment which are raised in the Legislative Council is an insult to their intelligence. If he does not get the opportunity of expressing his views in the legislation of his country, how is he ever going to learn? The time is ripe for native representation in the legislative Council, but the method of selecting Native members is a matter which requires serious consideration. I should like to see native representatives in the Legislative Council elected by the natives themselves in their own style for the present and later on probably a proper system of voting could be instituted. If the Administration consider it necessary to have nominated native Members, I hope that that will be only a temporary arrangement and that in the near future the native Members will be appointed by their own election or selection. If this motion is adopted the native Members of the Legislative Council should be indepen- 
dent and absolutely free from Government control The impotency of the Elected Members is becoming clearer to us day by day, and to say that the Elected Members represent a small minority of the population of Samoa is adding insult to injury.

If native Members were allowed to sit in the Legis-1 lative Council this could no longer be said of it."

Williams seconded the motion, mentioning the "success of the native Members of the Legislative Council in Fiji." 2 Richardson in reply explained that the 1923 Amendment Act envisaged the appointment of Samoan members of the Council.

"The New Zealand Government was keen and authority was given for two other members to be Samoans representing the remainder of the community - the Samoan race. I held a special $F$ ono and debated this question with them for a long time. I knew less of the Samoans then than I do now, and I had only one objective and that was the appointment of two native Members to the Legislative Council. I described the business of this Council and explained that while it would not deal with their ordinary native regulations and their social development, it would deal with matters of 1 aw, and many things they might wish to deal with would have to come subsequently before the Council. They considered this matter and it was freely discussed, and I hoped to get an affirmative reply, but it was in the negative. The reply said that they preferred at the present stage not to have any of their members on the Legislative Council. They were perfectly content to deal with their own affairs in their ways .... Another statement they made was that they were satisfied with the powers they had to care for their own affairs, and they asked that any laws which might be brought forward concerning native affairs should first be discussed with them, and if the Fono were not sitting they should be referred to a Committee so that they might consider all laws which were passed ... I realise that native representation will be beneficial when the time is ripe, but one cannot help feeling that the language difficulties would hinder the work of this Council and also the difficulty they would have in grasping the progress of our work, and until education has been made better, with no gaps in it, they will not be able to take 
their part in the Legislative Council that they otherwise would, but they are certainly taking the fullest part in their own affairs." 1

Nelson commented that "as far as I can see the Faipules are not at all anxious to see native representation in this Council because it would certainly do away with a certain amount of their own prestige." 2

Eventually the motion was lost, although Richardson promised to bring the discussion before the Faipules.

Elections to the Council were held again in December 1926 soon after the first manifestations of the unrest which developed into the Mau. All the sitting members were reelected and Richardson commented ${ }^{3}-$

"I am of the opinion that the successful candidates were elected chiefly on the vote of the half caste and German electors. Most of the British residents voted for the three unsuccessful candidates.

It is important for the Government to realise that the half caste community, which is in the majority here, will always support candidates of their own nationality, or those married into the country, and from my personal experience few of these have ideals which harmonise with the Government Policy for promoting the welfare of Samoa.

For this reason it is important to prevent elected members having any say in native affairs. The recent action of these members in sending emissaries around the islands to stir up the natives is a complete exposure of the methods they are likely to adopt if given any power over the natives. Therefore, the New Zealand Government should most strongly support the Administrator in the policy of dealing with native matters solely through the legally constituted native channels, and accept no political statements on native matters from local Europeans ... The lesson to be learned from the election is that the New Zealand

1 Ibid, pp.85, $86 \quad 2$ Ibid, p.86

3 Administrator to Minister, 3 December 1926 File I.T. 1/8 
Government should do everything in its power, as it is doing now, to promote the welfare and confidence of the natives. With this confidence assured all attempts to belittle New zealand Administration in these islands on the part of the half castes (registered Europeans) will be futile, because the Faipules, the leaders of the Samoan people, will always remain loyal under the existing policy and will speak with the authority of at least $95 \%$ of the population they represent."

By the time the new Council met in March 1927 relations between the Administration and the "European agitators" amongst whom Nelson and Williams were prominent - were very strained. Richardson took the opportunity of his opening statement "to say a few words for the guidance [of new Members] on the principles of governing this Territory, the functions of the Council, and their duties as Members.

"First of all bear in mind the fact that this is not a Parliament but a Council establi shed to consi der legislation submitted to it by the Administrator, and on which he wants advice, and your opinions based on your experience and on the best views and interests of those whom you represent ... I have mentioned on previous occasions and cannot emphasize too strongly that the prosperity of the European community who are directly represented on this Council by the 3 Elected Members, depends almost entirely upon the peace, order and good government of the Natives to whom this country belongs, and who comprise $95 \%$ of the total population... Therefore, they who deliberately attempt to unsettle the Natives, and undermine their confidence in the Government which not only protects them but contributes so much to their true welfare, are working against their own interests, the interests of the European residents, and the best interests of the Natives themselves." 1

The Elected Members were not given the usual opportunity of an Address in Reply but commented on the Administrator's "statement" in a memorandum of 22 March 1927 forwarded to him and to the New Zealand Government - 
"We agree with His Excellency in that the Council is not a Parliament, but we do not hold with him in the functions of the Council, as the Constitution of the Council, set out in the Samoa Act (Article 46) [sic] ... are not, as His Excellency states, confined to the consideration of legislation submitted to it by the Administrator, and on which he wants advice." 1

In acknowledging the memorandum, Richardson concluded -

"I deeply regret that 3 Elected Members of the Legislative Council who are pledged to loyal support of constituted authority should have participated and fostered a movement to undermine that authority.

Further discussion and publication of European agitation on Native matters will not restore the peace and harmony which prevailed prior to the attempts made by the Committee to disturb it, attempts in which you yourselves played a leading part, and which are resented by an overwhelming majority of the Natives themselves as well as a large section of the European population of this Territory." 2

A desire for Samoan representation in the Legislative

Council was expressed in the 1927 petition to the New

Zealand Parliament -

"16. To ensure the acquisition of a knowledge by the Samoans of the law, we sincerely wish to have representatives of the Samoan people in the Legislative Council, so that they deliberate in equal status with the European representatives, such as is done in Fiji and New Zealand." 3

The Royal Commission commented -

"We are by no means satisfied that there is a genuine demand among the Samoans for representation upon the Council, or that their presence on the Council would be advantageous. But, subject to what we have to say later, on the que stion of numbers, we see no real objection to Samoan representatives on the Legislative Council if a satisfactory method of election or appointment can be evolved.

File I.T. 1/8 2 Ibid

3 Roval Commission Report op cit, p.xIv 
"The suggestion that the Samoan and elected representatives on the Council should equal in number the nominated members appears to us to be unwise and dangerous. The casting vote of the Administrator as President of the Council is insufficient to give that stability to his policy which it ought to possess. He would have responsibility without power. The danger that the Native representatives might fall under the influence of the elected members is, in our opinion, real, and should be constantly borne in mind ..."1

The new Administrator (Sir Stephen Allen) al so had

doubts as to the composition of the Council. In an early

"outline of the political state of Western Samoa" he said -

"I am impressed by the fact that in the government of these Islands provision has been made in everything on too large a scale. The Islands are small, the population is small, especially the white element, and administration ought to be carried out on a relative scale. This leads to the enquiry whether a Legislative Council, at any rate, one with elective members, is necessary at all, or is it not a useless encumbrance? Certainly as constituted at present it is useless, and the elected members are incapable of any help or even of useful criticism. In the hearings by the Royal Commission of complaints against the Administration, for instance, when there was ample time to prepare a case, and there were actually some serious openings for finding fault with the finances of the Islands, these openings were entirely missed and the only faults found were on such trivial or false grounds as to be entirely ludicrous. This illustrates the calibre of the elected members. It also has to be considered that under the Mandate the Islands are to be governed in the interests of the native population; so that it would appear quite illogical to have European representatives on the Council (if any) apart from the official members. If there is to be a Legislative Council at all, it would appear that it should be constituted so as to contain only the official members and one or two representatives of the Samoan race who should be nominated in the first place and later might be elected if a satisfactory scheme for election be devised. In the present juncture it appears undesirable to have any Legislative Council, especially one containing elected European members, who are alien in all their aims and interests from the people for whom they make Ordinances. I 
should suggest that the provisions of the Act requiring a Council to be elected be suspended for the present at any rate." 1

Allen followed this with a memorandum devoted entirely to re-organisation of the Council ${ }^{2}$ -

"Referring to my recent conversation with you in Wellington, it was arranged that at an early date I should submit to you recommendations with regard to the Samoan Legislative Council, in view of the probability of amendments to the Samoa Act being made during the next session of Parliament. It is a convenient time to take the matter into consideration in as far as Samoa is concerned because the el ected members of the council hold office for three years and the next election takes place in November.

The Legislative Council consists at present of the Administrator, 6 official and 3 elected members. The qualifications of the elected members and the electors are set out in the Samoa Legislative Council (Elective Membership) Order 1923 and its amendment of 1923, but generaliy speaking the franchise is vested in all male 'Europeans' holding a certain property qualification. The half caste population has a preponderance of voting power, and it would seem that only a half caste, or a man married to a native or a half caste can hope to be elected...

The population of Western Samoa now consists of approximately 40,000 Samoans and 2,500 Europeans of whom all but some 400 are half castes or of mixed blood. These figures include of course persons of all ages. The electors at the last election numbered 222, and the total will not be many more than 200 at next election, so it will be seen that the three elected members are a large number in proportion to represent a small section of the community ...

I am still of the ... opinion [expressed in my memorandum of 7 January] and consider that logically there is no justification for the existence of the present elected members, and it would be best to have no elected European members at all. I realise, however, that the present system having been adopted, and no representatives of the so-called 'European' community having been admitted to the Council, the problem has become more difficult, and if the Council

${ }^{1}$ Administrator to Minister, 7 January 1929 . File I.T. $1 / 8$ 
is continued it is perhaps expedient to modify the constitution rather than to abolish entirely the 'European' representation. I suggest that the number of European representatives be reduced to one or at most two; one is ample in proportion to the number of the electors, though the value of the interests involved should receive some consideration, but two is perhaps the better number and a reduction to two would probably not arouse adverse comment. At the same time I suggest two Samoan representatives on the Council should be provided for, who should be appointed by the Administrator in the first place, with a further provision that at some future time to be prescribed by the Governor-Gere ral on the advice of the Administrator they should become elective on such a franchise and in such manner as should then be determined. I believe the appointment of Samoans to the Legislative Council would be appreciated in Samoa, and might remove the complaint that is often made now that legislation is passed by the Council affecting 'Samoans' by members elected by 'Europeans' without the 'Samoans' having any voice in the matter. It would also remove any cause for the cry of 'Taxation without Representation'.

I am aware that on one or two occasions the Fono of Faipule has dissented from the idea of Samoan membership of the Legislative Council, but I think that has been due to jealousy and a belief that such membership would lower the status of members of the Fono, and I doubt if the opinion of the Faipules on this matter has really been the opinion of Samoans generally. I point out too that the appointment or election of Samoans to the Legislative Council would further obviate the necessity (if any) for the existence of the Fono, which has really always been a mock body invested with sham powers.

The appointment of two Samoans to the Council, if accompanied by a reduction of 'European' representatives to two, would not jeopardise the official majority on the Council and it has been the experience in Fiji that on a division the native members almost invariably support the Government. I make the foregoing suggestions because I think there will be a growing demand for Samoan representation on the Legislative Council and the present is an opportune time for making changes; the present proposals would only increase the size of the Council by one member at the most, and I should be opposed to placing two Samoans on the Council unless at the same time the number of 'Europe ans' was reduced as indicated." 
In commenting to the Minister on the Administrator's memorandum, the Secretary of External Affairs (now C.A. Berendsen) said ${ }^{1}$

"It must be admitted that the Legislative Council as constituted is merely a creature of the Administrator anything that he wishes to propose will obviously be carried by the Council by virtue of the solid majority held by his officials and I think it is a fair criticism of the present arrangement that the Legislative Council as at present functioning has served merely as a sounding board for 'European' (including half caste discontent."

Berendsen then agreed with the Administrator that "the position has now gone too far for us to endeavour to retrace the steps that have been taken." After listing the Administrator's recommendations, Berendsen discussed the representation of Samoans on the Council -

"I think it may be expected that the Samoans will continue to demand representation on the Legislative Council but I have myself considerable doubt whether the nomination of two representatives by the Administrator will be acceptable. I think it is almost certain to meet with the criticism that the Administrator will choose Samoans who do not represent the majority of the people (in other words, who do not belong to the Mau) but it could be explained that these appointments would be put on an elective basis as soon as such a scheme can be shown to be feasible.

We would still, of course, be faced with the criticism that the number of official members, 6 , will exceed those of the unofficial members, 4 , but this is a criticism that one must face in any case."

Berendsen suggested to the Minister that he should recommend to Cabinet a reduction in the elective "European representation from three to two and that provision be made for two nominated Samoan members. He al so recommended that 
the Treasurer and the Collector of Customs be appointed as official members to replace the Director of Agriculture (whose duties were now performed by the Secretary of Native Affairs) and the Chief Judge (whose position on the Council had been the subject of considerable criticism). Cabinet approved these recommendations on 5 August 1929 and the necessary amendment to the Samoa Legislative Council (Elective Membership) Order 1923 was made. ${ }^{1}$

In due course the Administrator recommended that the first two nominated Samoan members should be the Fautua, Malietoa and Mata'afa. Berendsen on 9 November commented to the Minister -

"I hesitate to express any opinion on the subject myself but I feel it proper that the Government in considering this matter (which is important from the point of view of the administration of the Territory) should have the following observations in front of them:-

1. I pointed out in my memorandum of the 18th June, marked C, that the mere appointment of nominated members was not like ly to be regarded in 211 quarters as an acceptable representation of the Samoan race upon the council, especially in view of the fact that a majority of the Samoans have been for some considerable time antagonistic to the Administration. This has of course proved to be the case and the Government's statement of their intention to add these Samoan nominated Members to the Council has been to some extent ridiculed by the two Mau Press organs as a piece of window dressing only.

2. The appointment of the two Fautuas is open to at least two objections -

(1) Both have been strong supporters of the Administration throughout the whole Mau disaffection and though this is a recommendation from one point of view obviously I think the Mau cannot be expected to, 
and will not, accept them as representatives of the Samoan people as a whole. This objection applies particularly in the case of Mata'afa Malietoa's position is perhaps sufficiently strong to carry even Mau approval of his recognition as a Samoan representative.

\section{Both are in receipt of what is for a Samoan a}

very substantial sala ry in respect of their position as Fautuas. They are paid $\$ 132$ a year and a cynic might well raise the interesting question as to how far the salary paid to these two Samoans has encouraged or explained their loyalty to the Administration. However this may be it is plain that if these two gentlemen are appointed the Government and the Administration $w i l$ be particularly open to the criticism that the Samoan representatives on the Council obviously cannot be independent and free to criticize or discuss the proposals of the Administration while they are at the same time in receipt of a salary from the Administration and thus subject to its control and to its displeasure. This objection seems to me to be a strong one and if the Government approve of the nomination of Malietoa and Mata'afa I would suggest that before announcing the nomination the opinion of the Administrator should be taken by telegram on the advisability of dispensing with Fautuas altogether, or, in the alternative, of dispensing with the salaries payable to them and in either case attaching a salary of the same amount to the office of Samoan Councillor. There would not I think be the same objection to the payment of a salary to Samoan Councillors as there would be to the appointment of Samoan Councillors who are in receipt of a salary from the Administration by virtue of another government office. It will be noted of course that if a salary should be provided for the Samoan nominated Members it will almost inevitably lead to a claim for remuneration by the two European elected members.

3. If Malietoa and Mata'afa are nominated the Government will of course recognize the fact that any possibility, however slight it might be, of the appointment of Samoan Councillors leading or tending towards a reconciliation with the Mau in the near future would be greatly weakened. Both these gentlemen have been strong opponents of the Mau and consequently (it is only fair to state) strong opponents of the majority of the Samoan people. There would of course be many advantages in offering say one of the Samoan seats to a representative of the Mau, which contains in 
its ranks at least one Chief comparable in authority and descent to the two Fautuas and which undoubtedly represents a large proportion of the Samoan people. I do not suggest myself that this is either possible or desirable at the present time. My own opinion for what it is worth is that it is not possible yet but the Government should I think have this point before them when considering the matter.

4. When announcing the decision to appoint nominated Samoan Councillors you made it plain that though it was intended to proceed by nomination on this occasion it was proposed when circumstances allowed to make the necessary arrangements for the Samoans themselves to choose their representatives on the Council. Those Samoans who belong to the Mau may well be expected to doubt the intentions of the Government in this respect and I think any announcement of the appointment of Malietoa and Mata'afa as the Samoan Councillors should be accompanied by a very explicit statement by the Government and the Administration -

that these appointments are temporary only until it is possible to arrange for the Samoans to select their own representations,

that Malietoa and Mata'afa have been nominated not only as a courtesy to the two Fautuas and as a recognition of their high rank among the Samoans but as the most suitable people to hold the seats for the (it is hoped) short period before steps can be taken to facilitate direct selections by the Samoans themselves and finally

that a plain indication be given that the only impediment to such a choice at present is the continuance of the Mau movement of disaffection and that immediately this movement disappears the nomination of Malietoa and Mata'afa will cease and the Samons will be requested to choose their own representatives.

5. I do not suggest that any of these steps will have any real effect on the political situation but I do suggest them as worthy of consideration and I would recommend that a telegram on the following lines should be despatched to the Administrator before anything further is done in the matter:-

"CONFIDENTIAL. Government are prepared to recommend nomination of Malietoa and Mata'afa to Council but before doing so would be glad of your views on following points: 
(1) It is assumed that in your opinion no good purpose would be served by endeavouring at this juncture to allocate say one of the seats to a representative of the Mau.

(2) We see two objections to the nominations proposed -

nat they have been con'sistent Government

ters. This is of course from one point of recommendation but by reason of this fact not reasonably expect either to be accepted resentative of the disaffected portion or ans as a whole.

hey are in receipt of a salary from the stration as Fautuas. Could this objection oved by either dispensing entirely with $s$ or dispensing with their salary and in case attaching that salary to samoan llors. Otherwise we feel criticism would tified that they would not be independent.

you approve of a statement simultaneously nnouncement of nomination that the present tions are temporary only, are in recognition ition of Fautuas and of their status in but that when present Mau troubles disthey will immediately cease to hold office er that Samoans may choose their own repatives?" 1

elegram was approved and sent on 19 November.

(a) t. suppor view a we can as rep of Sam

(b) $\mathrm{T}$. Admini be rem Fautua either Counc i be jus

(3) Would with a nomina of pos Samoa appear in ord. resent

The draft $t$ same day saying -

Allen replied th

Referring to your telegram of the

"CONF IDENTIA:

19th Novembe:

inquiry has convinced me seats Council accepted by any prominent Mau Chief and would cause harm.

(1) Careful would not be its refusal

lietoa Mata'afa are two of the three most nt Chiefs in Samoa, therefore most accept-

(2) (a) $\mathrm{Ma}$ importa able to represe ntatives.

cannot dispense with Fautuas at present ak it unwise to pay salaries to Councillors.

(b) I and thi 
Criticism as to appointment of salaried official is academic only, and in practice for long past native representatives have been high salaried officials.

(3) I agree statement might be that Malietoa Mata'afa have been chosen as first Councillors because of their position as Fautuas, the ir pre-eminent rank in Samoa and the historic importance of their titles. Appointments are not to be considered permanent and opportunity will be taken when complete order returns new appointments to be made, and for Samoans to express their own wishes as to such. Statement should stop short of any promise of election as that is not compatible with present Samoan social structure."

The appointments were duly made by the Governor-

General on 23 November.

The Fautua contributed little to the discussions of the Council, which in any case met during the next few years only once or twice annually for the formal purpose of assisting the Administrator to make Ordinances. An election in 1932, when the Hons. I.H. Caruthers and A.R. Cobcroft (prominent planters) were returned as European unofficial members, made little difference to the place of the Council either in the Samoan Government or in Samoan opinion. Very briefly, it was of little importance in either. Just as the Fono of Faipule had ceased to represent the main force of Samoan opinion, so the Legislative Council was no longer even "a sounding board for European discontent". 1 The decisive events of Samoan politics had never taken place in the formal assemblies; now the main currents of political opinion were no longer even represented in these institutions. 


\section{THE RECONSTIIUTED FONO OF FAIPULE}

When the Hon. Frank Langstone and Mr J. O'Brien, M.P., visited Western Samoa in June 1936 "for the purpose of reviewing the political and economic situation obtaining in that Territory", they "found that there was still, in the mind of the average Samoan, a distinct element of doubt that anything would be done to erase the sources of old grievances and to remedy existing wrong $s^{\prime \prime} .^{1}$ In making proposals for reform, the Goodwill Delegation was guided by the principle that "to endeavour to rule Samoa by force is to adopt a policy which must result in failure and bring discredit and ridicule on the Administration attempting it." ${ }^{2}$

A list of the conciliatory measures recommended by the Delegation has been shown in Chapter II. In this chapter and the next we are concerned only with those that affected representative institutions in the Territory.

At a meeting with the Mau representatives on $15 \mathrm{July}$, the Delegations submitted a number of constitutional proposals which they announced would be recommended for the Government's approval. Among them were the following ${ }^{3}-$

1 Report of Goodwill Delegation to Prime Minister, File I.T.1/65 (Visit of Parliamentary Representatives 1936 - Goodwill Delegation) p.2 
(8) To revoke immediately the present Fono of Faipule and to arrange a re-selection so that the Faipule will be fully representative of the Samoan people.

(9) To fix the date for the re-selection of Faipule as at 30 September 1936.

At the final meeting of the Delegation's visit at which Nelson - who had just returned from his shortened period of deportation - was present, the Mau accepted the proposals put forward with the following minor amendment -

"The meeting requested that in consideration of the mana and rights of the present Faipule whose terms of office would not normally expire until 31 st March 1938, those who were not returned at the re-selection in september next be retained as additional Faipule until the expiration of the normal term, when a further re-selection will be made."

In conversation, the Delegation accepted this amendment and also agreed that the number of Faipule should be increased if it was necessary to give complete representation; in the opinion of the Mau, 39 were necessary.

In accordance with this agreement, selections were made in the districts and both old and new Faipules met at Mulinu'u on 30 September 1936. The Acting Administrator (Turnbull) in his opening address said:

"I have had placed before me nominations from the districts of the Faipule whom they have selected. It is but natural in the change over, such as we are having, that there should be many changes in the representatives. You have been assured by the Goodwill Mission that the present Faipule who have still 18 months of their term to run will continue along and with the addition of the Faipule who may be appointed under the new system. In the majority of the Districts it is not anticipated that any difficulty will arise as to the appointments. In a few cases there are some small matters in which 
I am in doubt, and it will be necessary for me to lay before the Fono the various aspects of the cases so that you will be able to consider and advise me so that a proper decision will be come to in making such appointments." 1

A great deal of discussion took place both inside and outside the Fono on the various nominations and there was a clear division between the old Faipules and the Mau nominees. Turnbull's confidential report to the Minister is quoted at length:

"The Fono of Faipule met on the 30th ultimo. The first business was to consider the nam es selected by the various districts. The Mau Organisation naturally took the major part in this, only a few nominations coming forward to the Native office direct from the Districts.

I had been on several occasions consulted by Mr Nelson, on behalf of the Mau, with regard to additional Faipule. Reference was made to the agreement entered into with the Goodwill Mission to the effect that 39 should be appointed ... The difficulty I was faced with was the fact that the Mau people desired to hold all the positions. I was opposed to the proposal that Vaimauga East (incl uding Lauli'i) should be disfranchised for benefit of Siumu; also that Fagaloa (Vaa-o-Fonoti) and Iva (Savai'i) Districts should not be represented as the people wished. The position, however, was met by the generous and unselfish spirit of the old Faipule, who saved embarrassment by retiring with dignity and grace for the contentment and unity of Samoa. Notwithstanding this they were somewhat bewildered and could not understand why, in view of their loyalty, they should be set aside.

Of the 39 seats 35 are held by new Faipule, 33 are Mau, 4 old Malo [government] Faipule and 2 were Malo officials.

The understanding of the Goodwill Mission was that the new Fono should only operate for 18 months. This view was, however, not shared by the new Faipules who were unanimous that their appointments should extend for

${ }^{1}$ Verbatim Record of Fono of Faipule 1936 on File I.T. $88 / 3$ by Administrator) 
3 years. It is not seen how the ginion of the Fono can be disregarded, nor does it perhaps matter." 1

Alipia, the spokesman of the Mau Faipules, described by the Secretary of Native Affairs (C.G.R. McKay) as "aggressive and suspicious in tone" ${ }^{2}$, insisted that the Samoans were not satisfied with the power given to the Administrator to appoint Faipules even though appointments were made on the nomination of the districts. He asked for an assurance from the Prime Minister that the Samoans would be given the right to appoint their own representatives. Such an assurance was given by Savage in a telegram of 5 October 1936. A similar attitude of suspicion was manifested later in the Fono when, after several remits had been declined by the New Zealand Government, the Fono declared that they had no confidence in the Acting Administrator and requested that a message be sent to the Prime Minister asking for the appointment of a new Administrator. In commenting on this incident by telegram of 18 october 1936,4 , Turnbull said -

"The last incident is recognisable to those who know Samoan ways as a characteristic piece of tactics calculated to frighten persons, against whom it is directed, into weakening on the point at issue.

... Throughout this Fono one has sensed that the Faipule have been manoeuvring for power. During the last few months expectations and hopes of virtual self-government have been at a high level and they are now suffering from a sense of disappointment."

After a further exchange of telegrams between Apia and Wellington concerning an increase in pay for Faipules,

${ }^{1}$ Acting Administrator to Minister, 15 october 1936 I.T. 88/3 2 Ibia (enclosure) 3 Ibid 4 Ibid 
the following message was sent to the Acting Administrator -

"... The Government are of the opinion that the Fono has now lasted long enough for a full discussion and expression of views on all matters brought forward by the Faipule and consider that the proceedings should now terminate wi thout further delay. If necessary you should terminate the Fono but as discreetly as possible." 1

In reply, Turnbull telegraphed that the Fono had concluded "in cordial spirit" and without reference to the previous telegram. "It can be said that after many years the Administration is now functioning free from non cooperation from any section of the people." In a report to the Minister of 12 November ${ }^{2}$, Turnbull elaborated this statement -

"Although no accouncement was made by the Goodwill Mission that the Constitution of the Fono of Faipule was to be changed, yet it was clear the Faipule expected a fuller degree of control verging on selfgovernment. It was not realised that the Fono was not a legislative or administrative body but only a Council of Advisers to the Administrator. Their attitude was most marked in not wishing to terminate discussions on any subject unt il it was settled according to their wishes. In short they were unwilling to recognise the authority of, or to accept, the decisions of the Mandatory Government or the Administrator. This naturally caused misunderstandings and delays ....

There has been criticism as to the length of proceedings, and we have not been free from misleading press statements, coloured by pre-conceived ideas, lack of appreciation of the true facts and apparently without desire to foster a co-operative spirit.

I am however quite satisfied that it was necessary in this new Fono, at such an important transition stage, that every opportunity should be given for free dis-

\footnotetext{
${ }^{1}$ Minister to Acting Administrator, telegram of 5 November 1936 ${ }^{2}$ Ibid Ibid
} 
cussion. Had the Fono been discontinued without an amicable conclusion there might have been a breakdown in negotiations and loss of goodwill."

One other incident associated with this Fono is worthy of mention. The Faipule expressed the wish to visit certain administration departments and the Acting Administrator agreed, in the hope that such familiarisation visits could only be of value. Unfortunately both the Faipule and certain officials regarded the visits not as educational but in the nature of "inspections", with a consequent period of illfeeling on both sides.

By the next meeting of the Fono (May 1937), Turnbull was able to report that "the European community are not so agitated and the Faipule having had these months to become accustomed to their new positions, seem individually to be more content". 1 However, as the Fono progressed it developed into a repetition of the previous meeting.

"It has been apparent since the first Fono of the new Faipule assembled last year that they are making a bid to exceed their consultative status by various forms of tactics ... though they refute any direct question on the point, an effort is being made to obtain a measure of power and authority which could have no other effect than putting the Faipule in a position to veto all acts of the Administrator, and incidentally in control of the Territory's Treasury ... The real desire of the Faipule is to have the power of making the appointments [to the Legislative Assembly] (and perhaps of dictating the appointees' policy) in their hands ... The Samoans outside the Fono are at present in a quiet and contented state, and even the Faipule individually are courteous and cheerful. It is only when they band together in numbers that these bids for power are made, and one wonders whether the Fono as an institution has sufficient advant ages to compensate for the difficulties that its existence creates. The policy of the Mau

${ }^{1}$ Acting Administrator to Minister, 27 May 1937, Ibid. 
towards it in 1926, before the present Faipule became Faipule was expressed as follows:- 'When the Samoans are represented in the Legislative Council, the time should soon arrive when that Council might suffice as the one Legislature for the whole of Samoa.' (A. 4b., 1927)" 1

This, as we shall see, was what eventually happened but much later than Turnbull perhaps expected.

In accordance with an undertaking given by the Prime Minister, the provisions of the Samoa Amendment Act 1923 concerning the appointment of Faipule $e^{2}$ were repealed and replaced by the following subsections ${ }^{3}$ -

"(1) The Administrator shall from time to time, by warrant under his hand and the Public Seal of Samoa confirm the appointment as Faipules of such Samoans as shall from time to time be elected or chosen in manner to be prescribed by Ordinance.

(2) No person shall be appointed as a Faipule under this section who is not qualified, in accordance with existing samoan usage and custom, to occupy the position of Faipule.

(3) All Faipules in office at the passing of this Act shall be deemed to have been duly appointed."

In an effort to completely meet Samoan wishes, the formal "appointment by the Administrator" was replaced by the unusual formula of "confirmation of the appointment"; similarly the method of election or choice was to be prescribed by Ordinance and yet the existing provision relating to "Samoan usage and custom" was retained.

The drafting of the Ordinance provided for by the Amendment Act raised some difficult questions which were

\footnotetext{
1 Acting Administrator to Minister, 9 June 1937, Ibid

${ }^{2}$ See p.85 above

3 Samoa Amendment Act 1938 (1938 No. 22)
} 
settled by the Administration in the spirit of compromise which marked this period.

It had become clear during the selection of the new Faipule in 1936 that if the Administrator was to appoint only those persons nominated by the districts there would have to be some certainty as to which villages were included within Faipule constituencies. An early example was the disagreement over the representation of Vaimauga East near Apia to which reference has already been made. The following extract from a letter of 22nd September addressed by Nelson to the Acting Administrator with a copy to Langstone illustrates the difficulties of adjusting the traditional Samoan concepts of fair representation to those held by the Administration and the Government:

"It was reported to me that at the discussion of the proposed additional Faipule for Vaimauga at the Fono in Mulinu'u last week, you informed the Fono that in conversation with me about the time of the inauguration of the present Fono, in September 1936, I told you that Vaimauga was reduced to one Faipule because its second Faipule was passed to Siumu, Tuamasaga South ...

I think I explained to you, at our first conversation on this subject, the basis on which the Samoans regulated the matter of representation for the Tuamasaga Province. Vaimauga on the north coast and Siumu on the south form one district, or two sister districts. The same relationship applies to Faleata on the north and Safata on the south. Faleata and Safata both had a Faipule so Siumu should also have a Faipule before Vaimauga gets a second, regardless of the number of people living in these districts, or sister districts. This is the Samoan way of arranging these matters."

Eventually the Administration carried its point that the populous districts near Apia should have increased rep- 
resentation but only after agreeing to raise the number of

Faipule to 41. In a memorandum of 16 January 1939 the Acting Administrator commented to the Minister ${ }^{1}$

"The main question is, of course, the number of Faipule and the districts to be represented. It will be observed that provision is made for 41 seats. The Goodwill Mission agreed to 39 Faipule but without stipulations as to the districts they would represent. The districts shown in the Schedule include the 39 agreed to by the Faipule and in my opinion the Administration is bound to this as a minimum number although the distribution is not ideal. Any attempted reduction in the appointments at present held would only cause controversy without any compensating benefit.

The Administration is committed to favourable consideration of an additional Faipule for Vaimauga which has been admitted to be inadequate ... and this is provided for in the schedule. There has, of course, been considerable objection by the Mau to this decision and it will no doubt be resisted strongly, and on diverse grounds, in the Legislative Council.

At the last Fono held September/October, the Faipule asked for an increase of their numbers to 45 . There is no justification for so many. The two largest and most populous (and increasingly important) districts are Vaimauga and Faleata which adjoin and indeed overlap in the Apia municipal area and I am disposed to recommend that each of these districts should have a representation of 2 Faipule and have so provided in the Ordinance. It may be said that this is in the nature of a compromise and that there is sufficient total representation already although inadequately distributed. It may quite truly be so, but it is preferable when in doubt to act generously, and the increase of 2 would cause much less upset than any attempt to add to Vaimauga and Faleata by taking away from other districts.

... I may repeat it is most probable there will be considerable discussion on this measure in the Council and the Samoan Councillors (also the Hon. Mr Nelson) are expected to oppose the addition of a Faipule for 
Vaimauga District ... In a I arge part [Mr Nelson's objections] will be offset by the addition to Faleata and the principle is strictly adhered to of having each political district represented by at least one Faipule and when considering more than one to have regard to the population requiring representation. Nevertheless, the question of Faipule representation for Vaimauga is one that may lead to a much controversy from Mau interests and indeed perhaps unpleasantness ..."

The Government agreed that Faipule representation was in future to provide for a maximum of 41 appointments and the Ordinance was passed in time to operate for the 1939 "election".; The system of "election" established enabled "the Samoan matai of each Faipule Constituency ... to elect or choose in such manner as they think fit one person whose name shall be submitted to the Administrator for confirmation of appointment as Faipule." 1 . Every submission was to be in writing signed by a majority of the matai of the Constituency. The term of appointment was to be for three years. Mary Boyd, commenting on the system of appointment, says -

"The procedure sanctioned by Samoan custom is for nominations to be made at district meetings with the unanimous consent of the district, and for the office of Faipule to be rotated between the different villages or sections ... [However] there has been a strong tendency for the largest village in the faipule constituency to assert its legal rights as a majority against the smaller village which has tried to defend itself by invoking the customary principles of unanimous consent and rotation of office. After long and difficult negotiations an agreement may be reached between the two, only to be broken on the next occasion. Sometimes no agreement is possible, and the law is left to take its course. A minority group may resign itself to the inevitable, or it may bestow more titles in an attempt to defeat the law, or it may nurse its grievance in active opposition or in non co-operation. Such factors help to explain why faipule elections 
have been so keenly contested, why they have taken from 4 to 7 months to complete, and why they have produced such a rich harvest of disputes." 1

Although this is a fair indication of the tone of Faipule elections it underestimates the advance towards representative government which the 1939 Ordinance allowed. In a number of cases it is knowm that the majority of matai in a district refused to re-elect a Faipule who had offended them in some way, often by becoming too high handed in his actions ${ }^{2}$. Similarly, the practice of rotating the right of selecting the Faipule between different villages within a constituency was not altogether harmful. Although it resulted in a loss of continuity of experience within the Fono it did enable a greater number of important matai at least to become aware of the activities of the central government. One of the interesting ways in which this changing membership allowed the Fono to make a real contribution to Samoan political development was through the provision of opportunities of leadership for younger, able matai. Because the Fono was no longer dominated by men of great length of membership - such as Toelupe during the 1920s - and because (at least during the 1940s) events in govermment were moving rapidly, ability and energy were added to $\underline{\mathrm{fa}} \mathrm{a}$ Samoa rank as criteria by which political reputations were made. Thus the leaders of the important Fonos of $1942-45$ and 1945-48 were both representatives of the newer class of Samoans with commercial experience, personal ability and political

1 "Western Samoa and Universal Suffrage" in Political Science

2 e.o. See Davidson, J.W. The Govt of Western Samoa op cit p.1E 
ambitions; both Fonoti (formerly of European status) and To'omata $\mathrm{L}$. were in their first term in the Fono when elected its leader, and both have continued to play important roles in the Government of Western Samoa as its framework has become completely Westerm.

The elected Leader of the Fono normally stated the opinion of the Fono as a whole. There were few speeches by other members in the fom al sessions attended by the Administrator, the Fautua and the Secretary of Native Affairs, but most issues were resolved beforehand in informal fa'a Samoa "caucus" sessions. Although the opinion of the Fono as stated by the Leader was normally given as the unanimous view of the Fono, this show of unity would often be reached only after a minority group had withdrawn its objection. In the context of modern government this traditional procedure had the disadvantage that a minority which may have accepted the majority view at the time of the Fono would not necessarily accept the course of action which that view implied; the district might then seek to reverse the decision through a direct approach to the Administration.

In summary, it seems that the main $v$ alue of the Fono of Faipule during the later years of the Mandate lay in its function as an outlet for the political aspirations of the higher ranking or ambitious matai. In pre-European social organisation "... it is clear that authority in practical matters was vested in the local groups, and that the wider district units together with the national system ... were 
concerned with ceremonial and warfare." ${ }^{1}$ A new outlet for energies which could no longer be directed towards "ceremonial and warfare" was, in the absence of adequate representative institutions within the framework of government, first found in the informal organisation of the Mau. After 1936 the creation of 279 official positions, elective every three years - Faipule, Fa'amasino, Pulefa'atoaga and Pulenu'u "was the device by which the Mau lost its character of active opposition" ${ }^{2}$. The real beginning of the Samoan movement towards sel $f-g o v e r n m e n t$ which is at the time of writing nearing its culmination, may be said to date from the time, about 1944, when the reforms of 1936 which provided for mere participation in advisory institutions such as the Fono ceased to satisfy the rising group of Samoans who wished to have some effective control of government, particularly of finance and staffing. The Faipule themselves took a practical step towards this objective in 1944 when they formed a Committee "which they hope will develop into an organisation with powers of supervision of Administration affairs if not an actual participation in Administration activities." 3 C.G.R. McKay, newly appointed Secretary of Island Territories, formerly Secretary of Native Affairs, commented: ${ }^{4}$

"This is history repeating itself - similar developments occurred prior to 1900 and a Mau Committee sat in Vaimoso for years. It springs from a Samoan propensity for dualism; - for every functionary their urge is to

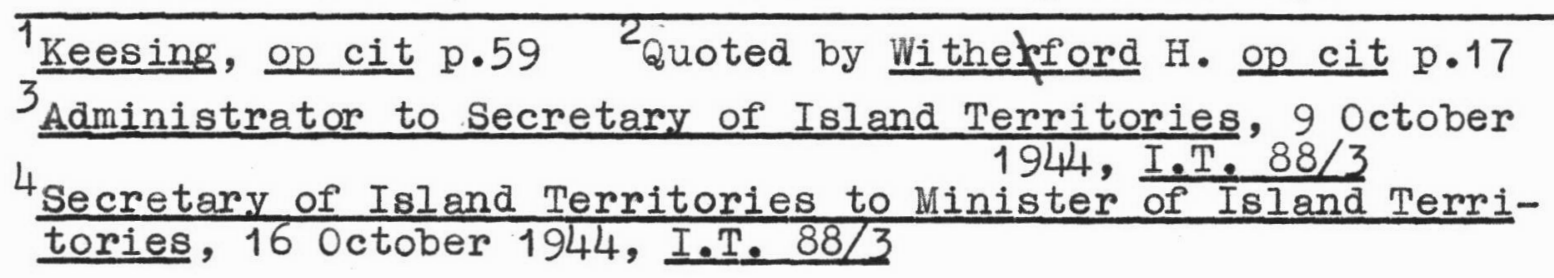


have an opposite or checking authority. They have no other form of finding outlet for characteristics which in other countries have means of expression through the debatings of democratic government.

In my opinion it is not far removed from the formation of another Mau."

Although the "Committee" soon drifted away, probably through the lack of government recognition, it showed that such younger and able Samoans as Fonoti and Tualaulelei (previously employed by an Apia commercial firm) were ambitious and prepared to take part in the Adminis tration. The spirit of this new group of Europeanised matai is indicated by a statement made by Fonoti concerning the "Committee's" suggestion that the Administration should buy all Samoan copra:

"Don't worry about what happened to Gen. Richardson. Times are different now. The Samoans were ignorant then. Now we of the Fono approach you for help ..."1 From this time on the Fono of Faipule declined in importance; important decisions associated with the post-war petition to the United Nations were made at Fonos of all Samoa, while after 1947 the most articulate of the Samoan leaders were found in the Legislative Assembly rather than the Fono. However, the more representative membership of the Fono and the continuing importance of the traditional political relationships which it reflected kept its status high outside Apia. Constitutionally, of course, the Fono still played an important role through its right to nominate persons for appointment as members of the Legislative Council and later the Assembly. 


\section{THE RECONSTITUTED LEGISLATIVE COUNCII}

The Goodwill Delegation agreed to increase the number of Samoan representatives on the Legislative Council from two to four, thus giving the unofficial members parity with the officials. The Mau at first wished to have six Samoan members, but eventually accepted the Delegation's offer. The Delegation also agreed that provision would be made "for the Legislative Council to discuss the Estimates of the Territory prior to their despatch to New Zealand for the approval of the Government, with a view to the Council's recommendations in regard to revenue and expenditure being fully considered." 1 When the Fono of Faipule came to discuss nominations for appointment as Samoan Councillors, old antagonisms quickly arose. Their first nominations were Nelson, Faumuina (President of the Mau), Tamasese and Tuala. No provision was made for Malietoa, the only sitting Samoan member - Mata'afa having died on 27 February 1936 - who had incurred the Mau's displeasure through his continued loyalty to the Administration. Turnbull, in forwarding the Fono's nominations to New Zealand, submitted that Malietoa "as the surviving ex-King of Samoa should not be deprived of any dignity." ${ }^{2}$ (The Malietoa family had already protested against the fact that only the Tupua line would be represented in the Council if the Fono's nominations were accepted.) The following day the Fono as a whole asked Malietoa to relinquish his position as Legislative

\footnotetext{
1 Report of Goodwill Delegation, I.T. $1 / 65$ op cit p. 6

2 Acting Administrator to Minister, telegram of 12 October 1936 , I.T. $88 / 3$
} 
Councillor, saying that he had previously offered to do so. He was unwilling to agree. In reply to this and other remits of the Fono, the New Zealand Government replied by telegram ${ }^{1}$

"Regarding Samoan representatives Legislative Council, Malietoa's position was never in question and definite undertaking of Goodwill Mission was that number of representatives was to be increased to four, making it necessary to consider three new appointments. By virtue of his status as a European Mr Nelson is not eligible for appointment to such a position and cannot be accepted as nominee. Tamasese, Faumuina and Tuala are eligible and acceptable and the Government's intention is that when their appointments are confirmed they will hold office until next election of European representatives. With regard to request of Faipule that Malietoa be asked to relinquish his position on the Council Government would greatly regret omission from the Council of a representative of the extensive and important Malietoa line."

In due course Tamasese and Tuala Tulo were appointed as Legislative Councillors "at pleasure", the intention being that they should hold office until the next election of European Councillors. (Malietoa continued to hold office under his existing warrant.) The appointment of Faumuina was not proceeded with pending a decision as to whether he would accept office in the Samoan constabulary. He eventually accepted a position. At the Fono of June 1937, Malietoa announced his voluntary resignation from the Legislative Council. In commenting on this incident Turnbull said -

"The Faipule had been urging for some time that all four seats in the Council for Samoans be open for an expression of opinion of the Samoans with regard to them and that Malietoa should relinquish his seat to enable this to be demonstrated. When he finally did so, the Faipule said that if the Administration would increase his stipend by addition of the $£ 50 \mathrm{p} . \mathrm{a}$. paid to Councillors not in

1 Minister to Acting Administrator - telegram of 16 October 1936 I.T. $88 / 3$ 
receipt of official salary they would re-elect him, but Malietoa replied that his resignation was definite and they should seek someone to take his place.

It is suggested that this be accepted as a sufficient record of the Hon. Malietoa's resignation; it seems hardly necessary to revive a somewhat delicate matter by asking him to put it in writing."

Malietoa's appointment was revoked in due course and the nominee of the Fono, Namulau'ulu Tivoli, appointed to replace him.

In a letter to Malietoa of 12 July 1937,2 Langstone his

thanked him for/service as a Councillor and went on -

"I personally regret the circumstances which have brought about your resignation ... When agreeing to the suggestion to increase the samoan representation on the Legislative Council from 2 to 4, it was never intended that the balance of your present term of office should be affected."

Earlier (on 10 June), Langstone had telegraphed Turnbull saying -

"The Government would regard the severance of Malietoa's connection with the Legislative Council as a matter for regret, but if he finally decides to resign his seat we must accept resignation." 3

In March 1938 the Acting Administrator raised the question of the term of office of the Samoan Councillors. He said that although langstone had been quite clear in his statement that the Samoan members should hold office until the next European election, "the Samoan expectation and belief is that the present appointments of Legislators, Faipule, and Pulenu'u will run for three years from 1/10/1936 ..." 1 Acting Administrator to Minister, 23 June 1937, I.T. $1 / 8$ I.T. $1 / 8$ 
In Turnbull's opinion the Government should fall in with the Samoans' wish, "... in fact it is preferable that the three years from $1 / 10 / 36$ should be completed. It is probably desirable psychologically that each year should have some political interest and change ... There is the further point of the desirability of keeping the European and Samoan elections apart as the respective interests are not similar."1

By memorandum of 26 April 1938, the Secretary of External Affairs advised "that in the circumstances the Minister is agreeable to the term of office of the Samoan Legislative Councillors being regarded as extending until the 1st october 1939." ${ }^{2}$

In the event, the composition of the Legislative Council at the session of 1939 was considerably changed. Upon his appointment as a Fautua in late 1938, Tamasese resigned as a Councillor and when choosing his successor, the Fono if Faipule took the opportunity of also nominating a Councillor to fill the vacancy which it had been intended to fill by the nomination of Taisi (O.F. Nelson).

The new members were Asiata Muese and Fa'alava'au Galu (the latter a former "Secretary of the Mau" and today Minister of Post and Telegraphs in the Samoan Cabinet). The European representatives also changed at the election held on 26 November 1938. By the Samoa Legislative Council (Elective Membership) Amendment order 1938, the franchise had been extended to

\footnotetext{
1 Acting Administrator to Minister, 17 March 1938 , I.T. $1 / 8$ 
all Europeans of 21 years and over in accordance with the undertaking given by the Goodwill Delegation (but against the advice of the Acting Administrator, the sitting Elected Members and the United Progressive Party of Western Samoa). The former property and income qualifications were dropped completely. Provision was also made in the order for the payment of honoraria to unofficial members of the Council. Nelson topped the poll with 338 votes (compared with 80 recorded in favour of the leading candidate at the 1935 election) with Dr C.M. Dawson also elected with 274 votes. Smyth, a sitting member, was third, while I.H. Caruthers, the other sitting member did not stand.

The presence of Nelson in the Legislative Council again gave the debates of the Council a more realistic tone. Since his return from deportation, Nels on had been quite openly advising the Samoans both in the Fono and in the Legislative Council. The first meeting of the reconstituted Fono in 1936 had requested that Taisi (Nelson) should be given the title of "Faatonu", or Adviser, and formally take part in the Fono. The Fono also nominated him as a Samoan Legislative Councillor and as one of their representatives on the Finance Committee (see below). When these recommendations were conveyed to the Government, Langstone telegraphed the Acting Administrator, saying -

"Apparently Samoans are anxious that Nelson be placed in official position. Two courses open to him. He can either elect stand for Legislative Council at next European election or he can change his status to that of Samoan and become either Fautua or Faipule as oppor- 
tunity offers. It Faipule anxious that Nelson be their adviser no reason why he should not act in unofficial capacity." 1

Nelson, who was now left without the prestige of an official position, elected to withdrawn from the Fono, although his residence at Tuaefu continued to be the place where Samoan political tactics were decided. The close relationship of Nelson to the Samoans was described by Tuala when Nelson eventually took his seat in the Council -

"Although the Hon. Taisi stands on the European side, yet we still look to him to help us representatives of the Samoans in all matters to advance the welfare of the whole community." 2

In August 1939 the Fono of Faipule submitted four names for appointment as Samoan Legislative Councillors from 1 October. Turnbull described the method of selection as follows ${ }^{3}-$

"... the Faipule invited Mau delegates to meet them, and voluntarily reduced their own numbers so that a secret ballot could be held, equal numbers of faipule and Mau delegates participating.

Ballots were then mun off in pairs, as between nominations by the Faipule, and nominations from the Mau with the following results -

Faipule nominees

1. Tuala Tulo, sitting member Lost

2. Alipia Siaosi F.P. Won

3. Faolotoi

Lost

4. Pulepule

Lost

\section{Mau nominees}

Fa'alava'au Galu sitting member

Won Vui Manu'a

Lost

Leleua Siavao Won Won "

The four successful nominees were appointed from 1 October 1939 and on the nomination of the Fono in August 1942 their

${ }^{1}$ I.T. $88 / 3$

Legislative Council Debates, $1939, \mathrm{p} .4$

3 Acting Administrator to Minister, 16 August 1939, I.T. $88 / 3$ 


\section{5.}

were

appointments/confirmed for a further three year term from

1 October of that year. Alipia died during 1943 and was Hepracearid 1 September 1943. Tualaulelei's nomination by the Fono of Faipule marks a significant new phase in the Council's development. This significance lies not so much in the contribution which Tualaulelei was able to make to the Council (which was still a fairly ineffective body); his appointment marked, however, the recognition by an influential body of Samoans that their increasing desire for greater participation in the activities of Government needed to be matched by evidence that there were Samoans who could usefully take their place in European institutions. It also showed that the Fono was prepared to accept the proposition that the qualities required for success in such institutions as the Legislative Council were not necessarily the prerogative of those of high ranking matai title and long service to the Mau organisation.

Even in the turbulent political situation as sociated with the Trusteeship Agreement and the United Nations Petition the Legisl ative Council was of little importance. The most important political matters were decided at Fonos of all Samoa in which the Fautua (particularly Tamasese) took a leading part; the Council met only to consider the annual estimates and to pass any legislation which the Administration had ready for introduction. In 1944 there were four sessions of the Council which totalled 23 sitting hours; only the "budget" session occupied more than one day. During 1945 the three 
sessions occupied only eleven hours but in 1946 the sitting time increased to 42 hours over four sessions. ${ }^{1}$

The low regard in which the Council was held by the community is not surprising in view of its limited functions. One possible line of development had already been by-passed during the visit of the Goodwill Delegation. It was then agreed to establish "a Finance Board to go fully into matters of expenditure". The request to establish such a board came from the elected members of the time - Smyth and Caruthers who, as businessmen, were primarily concerned with effecting economies in administration. The Finance Committee eventually constituted comprised the Administrator (as Chairman), the Secretary to the Administration, the Treasurer, the Secretary of Native Affairs, three Samoan members (nominated by the Fono of Faipule) and one European (nominated by the Administrator). The Committee, which held its first meeting on 10 May 1937, met to consider the estimates before they were referred to the Legislative Council and also to receive a report on the financial situation at the end of the calendar year. The Committee achieved little. The unofficial members maintained that this was because they received insufficient information but the primary reason was that the Committee was unnecessary. From 1938 on the Legislative Council discussed the estimates before they were forwarded to the Minister (as had been the practice until 1927); little was gained from the suggested advantage that the Finance Committee would be able to con- 
sider the estimates in greater detail than the full Council because the two bodies were quite distinct. By 1947 only one unofficial member of the Finance Committee was also a member of the Council. Eventually the Committee did become a Committee of the Legislative Assembly, and as such had some significant influence on financial policy

When the 1947 United Nations Visiting Mission reached Samoa they -

"... encountered strong criticism of the present Legislative Council from a wide variety of persons interviewed, Samoan and European. The Council possessed 'no real power', it was said; to persuade capable Europeans to stand for election is most difficult; its proceedings are 'a farce'. Samoan leaders, in their evidence, showed that they consider control of the legislative authority as the crux of selfgovernment." 1

The New Zealand Government agreed and with the establishment in 1948 of a Legislative Assembly with a majority of elected members ( 11 Samoan and 5 European), Western Samoa took the first big step towards independence.

${ }^{1}$ Department of External Affairs, Western Samoa 1947 - Report to the Trusteeship Council by United Nations Mission to Western Samoa, Government Printer, Wellington 1947, p.30 


\section{DISTRICT AND VILLAGE GOVERNMEMNT}

J.W. Davidson begins his 1947 survey of the Government of Western Samoa with a reference to the belief (which he ascribes to many concerned with Samoan administration) "that the problems of [Western Samoa's] government are insoluble." The practical consequence of accepting this viewpoint was in Davidson's opinion, "... the withdrawal of the Administration from the ordinary level of the people. Except for the work of doctors and teachers, the Samoan villager tends to regard government as being little more than a remote and impersonal system operating in Apia ... In the autonomous village communities the law has in actual fact almost ceased to run."1 We have already remarked on the pattern of Samoan administration established by the Germans. Recognising the status quo, both the Constitution Order 1920 and the Samoa Act 1921 were silent on the topic of government outside Apia. In the early years of New Zealand rule the Administration's sole contacts with the villages away from Apia were on the Administrator's regular malagas, and through the rather unsatisfactory medium of the Fono of Faipule. The Department of Native Affairs was concerned mainly with the quasi-judicial work associated with claims to Samoan $l$ and and titles and with the collection of various taxes. It was represented in the outer districts by Resident Commissioners at Fagamalo in Savai'i, and until 1923 at Aliepata at the far end of Upolu. There were also a number of agricultural inspectors in the districts, but 
they were of course without authority in "Native Affairs". Soon after his arrival in Western Samoa in March 1923, Richardson requested authority to make native regulations with the advice and consent of the Fono of Faipule. ${ }^{1}$ When the Minister declined to give the Administrator power to make regulations in this manner, Richardson submitted leng thy regulations for enactment as a New zealand Order in Council. In due course the Native Regulations (Samoa) Order 1925 was made. $^{2}$ As well as providing for the establishment of District Councils "for the purpose of Native self-government" and village committees, the order covered the following topics: Cleaning of Villages; Samoan Houses; Cemeteries and Burials; Latrines; Water Supplies; Keeping of Animals; Gatherings in Villages; Roads Village Funds; Plantations and Food-Supplies; The Abolition of the "Aitagi" or Death Feast; Treatment of Diseases; Breaches of the Law by Village Communities; and Reservation of Native Land for Church Purposes.

The complex system of District Councils and Village Committees now established was the first real attempt to achieve an effective inter-relationship between the Administration and the traditional $\mathrm{fa}^{\prime a}$ Samoa system. The twenty District Councils comprised representatives of the villages within the District - which although based on the traditional divisions might have been extended to give recognition to populous areas - and the local Samoan officials, the Faipule, pulefa'atoaga (plantation inspectors) and pulenu'u (village 
registrars). The Faipule was to preside.

The scheme was hardly under way when the Mau undermined any chance of success it may have had. In part, of course, the innovations in local government were among the contributing factors in the unrest which enabled the Mau to take root. There was no great feeling of need amongst the Samoans for this new system; it held no readily apparent benefits, yet it seemed to threaten the traditional authority of the Ali'i and Faipule. If the Ali'i and Faipule were to remain in authority, then the Samoans could see no reason for these new creations of the Administration. The fact that the new Councils seemed to further bolster up the prestige and power of the Faipule and other officials was in itself sufficient reason to distrust the motives behind it and to provide an excuse for creating a rival Mau komiti with similar jurisdiction.

By 1928 the experiment had clearly failed. The new Administrator (Allen) requested an amendment to the Native Regulations (Samoa) Order 1925 providing for the appointment of "District Officers" to perform the duties of the District Council. The amendment was made in due course. ${ }^{1}$ These District officers appointed from the ranks of the special police, performed a very useful function; living in the District and speaking the language, they acted as the eyes and the ears of the Administration as well as being the strong right arm. As was to be expected, they were unpopular with 
certain sections but generally they identified themselves

in a most useful manner with the District in which they

were stationed.

After the rapprochement between Mau and Malo of 1936, the Administration put forward another solution for what seemed to be an increasingly difficult problem. In a very valuable memorandum of 2 June $1938^{1}$, Turnbull discussed the "spheres in which law and custom are sharply opposed."

"In a village of, say, 600 inhabitants, the village life and activities are controlled by some 30 or so chiefs - so far as the young er generation have not learned that, legally, they may flout the customary authority. These leaders endeavour to keep in order and supervise the labours of perhaps 150 young men. The latter's functions include most of the communal work required to provide for visitors, the making of village pig enclosures, bathing pools or roads, or searching for rhino beetles, any of which would be unenforceable now by a law emanating from one central authority. Again, all persons are required to take their part in village ceremonies, such as the "tautoga" a weekly ritual in which they swear inncence or otherwise of minor offences complained of during the previous week. If any persons refuses to conform to these observances what can the chiefs do? Under the old customs they would administer corporal chastisement, or more commonly order the other taulele'a to do so. If they impose such a penalty theynow break the law ...

A similar situation arises between matai themselves. On any occasion calling for communal effort, such as the reception of visitors (of no small importance to a socially minded people), in contributions towards a village boat, work in connection with water supplies, cemeteries, or plantation roads (Iorries now being employed) or in any village festival a small levy in labour or cash or kind is made. Any matai who ignores his duty to the village group in these ways can create much irritation, and the resentment against him is slight as compared with their own feeling of bewildered incompetence to do anything about it that might not later form the substance of a complaint against them-

Acting Administrator to Minister, File I.T. 67/34 (Legislation Native Regulations Empowering Order 1924; Native Regulations 1938) 
selves. As the law stands at present such would be well founded. (In former times persistent defiance was penalised by banishment; I should make it clear at once that I do not for a moment advocate legislation or compulsory banishment, but the characteristics of a people who practised it create a need for something to be put in its place.)

Coming closer to the spheres of Government activity, one may appreciate how this large body of chiefs could perform valuable functions if only they were empowered to do so - for instance, in the directions of controlling the coconut beetle, wandering pigs and other pests, and ensuring in various ways the general cleanliness and sanitation of village life. Several of our villages and significantly those nearer to Apia, are of unkempt appearance; the real reas on for this is an apathy on the part of the chiefs who realise that if they do give instructions their people know they are free to disobey them. Under such conditions one feels it is almost hypocrisy in Government to expect the chiefs' co-operation and by its own laws to deny them their customary ways of employing it.

It may be asked why the problem is raised now, when law has already been established here for over a generation - a little enough time indeed. The reason is that the older chiefs who in their youth (prior to 1900) were unhampered in enforcing the carrying out oI their orders are only now dying away, while their successors have to deal with a relatively educated younger generation who are more quickly appreciative of legal powers and limitations. This has caused a time lag in the changes and problems of civilisation finding their full effect. It is a commonly heard remark that such-and-such a chief has not the personality or is not respected as his father was. The reason is that, circumscribed by the law and its restraints, he has not the opportunity to be. While on the one hand this frees his retainers of the risks of tyranny or oppression, it also produces among them the usual effects of slackness and loss of discipline and it may be that none of those concerned is a great deal happier for the change."

The Administration's suggested remedy for this state of affairs was the recognition by Government of the Ali'i and Faipule of the village as a statutory authority competent to issue by-laws (subject to the Administrator's approval) and to punish breaches of these by-laws. The scheme was 
severely criticised by Berendsen, primarily on the following grounds -

(i) that it involved the formal recognition of an undemocratic concentration of power in the hands of the chiefs and orators, and

(ii) that the Ali'i and Faipule in their judiciary capacity formed a very defective court - notably in that they were passing judgement under laws made by themselves and that they were also responsible for the prosecution.

In fact the scheme was not as "undemocratic" as it appeared; the matai are in close touch with the opinion of the rest of the community. However, Berendsen's objections convinced Langstone that there were doubts of the long term value of the proposals and no action was taken. The existing regulations providing for "native authorities" were repealed and government in the districts and villages of Western Samoa reverted to the completely traditional as it had been before 1925.

The experience of the twenty years since 1938 including the disruptive period of World War II - suggests that neither the conflict between European law and the fa'a Samoa feared by the Administration nor the undemocratic nature of the traditional institutions were really the pressing problems they seemed. Although education and the influence of a money economy have heightened the rift between traditional authority and the younger elements, particularly around 
Apia, the difficulties have been primarily economic rather than political. When sufficient jobs have been available the "detribalised" Samoan of Apia has settled into a life not too far different from the New Zealand suburb dweller; those who have remained within the bounds of village life have generally been content to accept both its burdens and its security. There has been no desire for institutions of local government because there have been few problems which cannot be dealt with within the existing framework; there is some doubt whether this situation can be maintained as the employment market of Apia becomes saturated. Undoubtedly as Apia becomes less of an escape valve for the discontented in the villages, the desire for development, assisted by more widely representative institutions of local government, must come to the districts. But this is outside the scope of the present study which has merely sketched the attempts made to develop a viable system of local government between the wars; its significance for political development as a whole is touched on in the final chapter. 


\section{CONCLUSION}

Robert Louis Stevenson, describing Apia, "the seat of the political sickness of Samoa", in 1892 also indicated the nature of a political problem which has persisted to the present day.

"[The reader] will remember that he is in the Eleele $\mathrm{Sa}$, the "Forbidden Soil" or Neutral Territory of the treaties; that the magistrate whom he has just seen trying native criminals is no officer of the native King's; and that this, the only port and place of business in the kingdom, collects and administers its own revenue for its own behoof by the hands of white councillors and under the supervision of white consuls. Let him go further afield. He will find the roads almost everywhere to cease or to be made impassable by native pig-fences, bridges to be quite unknown, and houses of the whites to become at once a rare exception. Set aside the German plantations, and the frontier is sharp. At the boundary of the Eleele Sa, Europe ends, Samoa begins. Here then is a singular state of affairs: all the money, luxury and business of the kingdom centred in one place; that place excepted from the native government and administered by whites for whites ..." 1

This tradition of exclusiveness between the European and Samoan communities has added to the fragmentation and instability inherent in Samoan political life. The islands are too small and the ties - particularly of family (aiga) relationships between European residents and Samoans so close that an artificial political division which did not provide for the eventual integration of both communities was building up problems for the future.

The effects of this segregation of "Europe" and "Samoa" were not too serious during the German regime. However, the 
advent of New Zealand in Western Samoa coincided with the first real signs that the Western influences which Samoa (alone amongst Polynesian islands) had resisted for so long were beginning to weaken the traditional ways. The uniform pattern of Samoan life was being disrupted by the ramifications of commerce and the spread of alien ideas; an increasing number of Samoans were straying from the accepted standard of the fa'a Samoa and more and more situations were arising which had no precedent in Samoan experience. The political significance of these social changes was two fold: on the one hand, a class of Samoans was growing who, although remaining attached to the traditional system, were also developing a familiarity with European ideas and techniques, largely through participation in the commercial life of Apia; on the other, there was a reaction away from European influences, a tendency to look back towards a past Samoan "golden age" before the 'palagi ${ }^{1}$ came, when the matai was secure in his authority and in his traditional pursuits.

Keesing remarks on similar situations where "under [the impact of alien ways] ... a people tends to find solace or refuge by retreating into what remains of the old ways." 2 In Western Samoa the innovations sponsored by the Administration in the mid 1920s undoubtedly strengthened this reactionary tendency. In circumstances where unplanned changes were taking place rapidly throughout the social system, Richardson's attempts to force the pace of Samoan development can only be

\footnotetext{
1 The European

$2_{\text {Keesing, op cit. }}$. 478
} 
regarded - in the wisdom of hindsight - as unrealistic. The Administration's main error lay in under-estimating the unity of samoan culture. In directing his reforms at the restrictive by European standards - influence of the matai system, Richardson set off "uncontrolled reverberations throughout the cultural pattern"1. His plan to individualise land holdings, al though economically sound, threatened the Samoan concept of pule, the trustee relationship of the matai to family land, and thus the very basis of the system; similarly with his encouragement of individual thrift and the prohibition of much of the ceremonial of Samoan life. The Samoan was, as yet, without the economic stimulus which forced the New Zealand Maori to adapt his traditional culture; the Samoan could neither understand nor see the need for these 'palagi innovations; they seemed to threaten the very basis of the traditional way of life and, if he was a matai, his traditional authority. The Samoan reaction to this bewildering situation was the Mau and a decade in which the inevitable course of social change proceeded without official interruption or even guidance. Keesing's assessment ${ }^{2}$ of the Mau is now generally accepted. "The Mau", he said in 1934, "is essentially a manifestation of a cultural-pathological condition in Samoan life, product of the long period of conflict, repression, psychological stress, lack of interest and excitement, social disintegration, baulking, and general unbalance, and malaise, aggravated after 1924 by sudden official pressure."

1 Keesing, op cit, $p .477$
2 Ibid, $p .177$


Although the Mau undoubtedly derived its strength from the unsettled state of Samoan society, its main impetus came from the "European agitators" with the assistance of some of the class of Europeanised Samoans mentioned earlier. Here was a situation unusual in colonial history - the white settlers joining with the natives against the Administration. In pursuing to its logical but unrealistic conclusion the Mandate principle of the paramountcy of Samoan interests, New Zealand had forced the local Europeans closer towards the Samoan community. The Administration's policy had, of course, most honoured antecedents; the protection of native interests was always the basis of British Colonial policy:

"It is a cardinal principle of British Colonial Policy that the interests of a large native population shall not be subject to the will either of a small European class or of a small minority of educated or Europenaised natives who have nothing in common with them and whose interests are often opposed to theirs ..." 1

But Western Samoa was not British Africa. The "small European class" - some 5 per cent of the population - were not temporary exploiters of the natural resources of the Territory but people of long connection with the country; in almost every case they had close family relationships with the Samoan community. Similarly, the "small minority of educated or Europeanised natives" had much in common with the great Samoan majority; the Territory (and in particular the town of Apia) was too small for any Samoan to hope to live in the Territory and escape his traditional obligations. In any case, few wished to do so; the ${ }^{1}$ Lord Lugard quoted by Wheare, Joan, The Nigerian Legislative Council, London, $1950, \mathrm{p} .33$ 
all-pervading influence of the social system was such that Samoans employed either in commerce or by the Administration saw this experience as an asset which gave them greater power within Samoan society, rather than as a weapon which would help them to escape from its ties.

It was from this class of "mediators" 1 - both local European and Samoan - that the moving spirits (not necessarily the nominal leaders) of the Mau were drawn. The same group provided the most vigorous of the nationalist leaders who emerged during the Second World War. Of particular significance for the constitutional issues discussed in this study are the part-Europeans of whom O.F. Nelson is the outstanding figure. Nelson was quite ambivalent in outlook. Not only was he the leading businessman of Apia and the first Elected Member of the Legislative Council; he was also the holder of the high matai title Taisi, connected with the royal Tupua family, and therefore a person of considerable status in Samoan affairs. Perhaps, as the Administration avowed, Nelson was moved in his "agitation" because of concern for his business interests. His continued personal sacrifices cannot, however, be explained by that alone, nor can his political activities be attributed entirely to personal ambition; a more likely cause is to be found in the Administration's brusque refusal to allow the local Europeans even to consider Samoan affai rs. Regarded at the best in a rather patronising manner by the Administration ${ }^{1}$ For a discussion of this important concept see Keesing, F.M. and Keesing, Marie M. Elite Communication in Samoa - A Study of Leadership, Stanford, 1956, esp. p.203 et seq. 
(and more often as intruders and exploiters) the part Europeans were driven closer towards the Samoans; the very course which Administration policy aimed to prevent.

This coming together of the leaders of both the Samoan and the European communities in the Mau organisation suggested that the great long-term problem which has troubled Samoan governments from the "kingship" to the present Cabinet, could be overcome. Most problems of government in Samoa stem from the fragmentation and complexity of Samoan society. Until very recently the Samoan has had no real feeling of national consciousness. He has been noted for a racial pride sometimes bordering on arrogance, but politically his allegiance has been to his matai and to his family; if he has himself been a matai he may have identified himself in a more occasional way with the interests of one of the larger family groupings. Unfortunately, the tenacity of the matai system, for all its social advantages - particularly attractive by comparison with other Pacific Territories where the traditional system has broken down - presents a number of obstacles in the way of Samoa's development into a modern state. Stevenson saw that Samoa could not maintain its communal subsistence economy in the face of outside influence; General Richardson attempted to develop the Territory "beyond the vision of the Samoans"; modern economists and govermment statements have urged the need for economic development if Samoa's material standards 
of living are not to drop back. ${ }^{1}$

Until the beginning of Trusteeship successive Administrations - in accordance with the currently accepted principles of colonial policy - strove to prepare samoa to take its place in the modern world, by the development of the country's agricultural resources and through the raising of standards in health and - to an insufficient extent - education; "selfgovernment" was always an ultimate but far-off objective of policy. Only over the last decade or so has this belief that a sufficient standard of economic and social development must precede political advancement - been superseded by the opposite view that material achievements take place more rapidly if political tensions are relaxed through the increasing participation in government of the local people. In Colonial Africa - the area where British Colonial policy developed considerati ons of geography alone seemed to present an insurmountable barrier to schemes of Colony-wide political development. Similar considerati ons applied in the small islands of Samoa where the lesser problems of communication were balanced by the existence of a strong i ndigenous social organisation which had no "chiefs" with undisputed authority the usual agencies of "indirect rule".

Richardson's crucial Administration illustrates the diffi-

7 "Is [Western Samoa] to be a progressive industri ous country desirous of and anxious for socially satisfying and modern standards of living, or is it to become a place in the Pacific retaining its age-old customs and traditions, isolated from the upsetting influences of the changing world?" Western Samoa Financial and Banking Survey, Govermment Printer, Wellington $1957, \mathrm{p} .13$ 
culties encountered in framing Samoan policy: on the one hand he pushed forward with the classical policy of encouraging native economic and social development through a variation of "indirect rule" i.e. the use of the Faipule as an official and a guide to the District Councils; on the other, he thought of the Fono as an embryo "Native Parliament." His second line of policy suggests that Richardson recognised that if Samoa was not to remain a Pacific back-water it required an effective system of government above the village level; only if the fragmentati on and jealousies of Samoan life were overcome could the demands for improved standards and services already being made by some Samoans be answered. Eventually, as has been described in earlier chapters, the administrative system established by Richardson broke down completely, and the negative influence of the fa'a Samoa dominated the activities of government over the next decade. Could this unfortunate and unproductive period of Samoan history have been avoided? The answer is probably in the affirmative; but with this background of the problems and objectives of official policy we must now assess the adequacy or otherwise of the representative institutions described earlier in this study.

First, the Fono of Faipule. Although obscured during Richardson's unfortunate attempts to build up its status as a body representative of all Samoa, the original function of the Fono was to provide a regular opportunity for the Administrator and the government representatives in the various districts to meet together. With only a very small Native office, the early 
Administrators were forced to rely upon these regular meetings of the Fono and on their malagas around the villages to ensure consistency in administration. (The absence of any counterpart to the "District officer" until the abnormal conditions of the 1930s seems an unfortunate gap in the system of Samoan administration.)

The main function of the Faipule was to take part in this consultative body. He was also a government agent in his district, although he had no executive authority; he could merely transmit the decisions of the Administration to the matai of his district; he could not enforce decisions but only report any breaches to the Administration. Any influence - whether for good or for bad - which the Faipule exercised in his district he owed to his position within the traditional system. The Faipule's official appointment was incidental to his fa'a Samoa role as an important matai; it conferred upon him the privileges of a salary and prestige within the hierarchy of government but, in itself, added little to his personal authority. of course the Faipule could use his official position to improve his status beyond that conferred by his matai title by manipulating a Samoan version of the "pork barrel"; the 1927 Royal Commission Report discusses a number of charges of this nature.

There was thus a conflict in roles between the Faipule's position as an Administration official and as a matai with fa'a Samoa rights, duties and obligations. Whether or not the Faipule owed his appointment to the district or to the Adminis- 
trator he could not dissociate himself from the traditional political and social system. There were one or two districts such as Falealili in Upolu - where the supremacy of a certain chief was undisputed within the traditional framework and where this chief also happened to be the Faipule; in such a case the Administration experienced few difficulties, so long as it maintained good relations with the Faipule. But in general the Faipule was merely a contact between the chiefs of a district and the Administration. The efforts of certain Faipule to do more - probably in their own interests rather than those of the Administration - were among the efficient causes of the Mau and the boycott by the majority of the Samoans of the appointment of Faipule and of the Fono.

As officials the Faipule were of little value. (The Administration would have remained in much closer contact with the people by working through the institutions which the people still recognised - the Alii and Faipule at the village level and, in matters of wider importance, fonos at the sub-district and district level.) And because the Faipule were officials their participation in a central representative institution was of correspondingly less value. Even after its reconstitution in 1936 the Fono had only a negative influence on government; its united opposition thwarted a number of Administration schemes and the decade 1936-45 is often characterized as a period of "marking time". The new Fono did, however, serve 
as a selective institution where a new category of Samoan leaders came to the fore.

Towards the end of the period covered by this study, and increasingly in the early years of Trusteeship, the newer more aggressive Samoan leaders found places in the Legislative Council ${ }^{1}$. Where the Fono, dominated by traditional Samoan considerations of rank and of procedre, could exercise only a negative and secondary effect on government activities, the Legislative Council provided opportunities for the Samoans to come to closer grips with the real issues of administration, particularly through their participation in financial discussions. While the financial questions were excluded from its purview the Fono of Faipule was merely a collection of district delegates; similarly, while the Legislative Council was without effective Samoan membership and was prohibited from discussing questions affecting Samoan affairs, it could hardly provide a focus of national interest. Even when more truly, representative Samoan members were added after 1936, the Council's small membership, its complete lack of ceremonial, its official majority and infrequent meetings did not make it a very satisfactory outlet for the energies of those ambitious Samoans who wished to extend their political activities beyond the traditional organisation.

It is now possible to attempt an answer to the question posed earlier in this chapter: could the Mau have been avoided? In so far as such a question can ever be realistically answered 
after the benefit of 30 years further experience, the answer is: Yes. Two main considerations influence this view. First, the history of other dependent territories and of Western Samoa itself under Trusteeship supports the following principles: that no people, irrespective of their level of education, their standards of material achievement or any other social factor, can be governed without their consent; and that this consent is more likely to be gained when the governed have some feeling of identity with the government. The practical implication of these principles is that the path of wisdom for countries administering dependent territories lies in granting concessions towards self-government one step ahead of those demanded by a politically significant group in the community; in the case of Westerm Samoa, the higher echelons of mataj. The second consideration leading to the view that the Mau unrest could have been prevented, involves official policy towards the part-European community, the topic with which this final chapter began. By providing constitutional machinery which would have fostered the identity of the two ethnic groups comprising the population of Western Samoa, the Administration vo uld have achieved two things: it would have gained as allies men who proved dangerous enemies when associated with the Samoans; it would also have assisted Samoan development in all fields, because as Administrators so of ten repeated, the interests of the part-Europeans, mostly traders, could only be aided by the improvement of standards amongst the Samoans. 


\section{7.}

Translated into action, these considerations suggest that an acceleration of the constitutional reforms of the Trusteeship era would have been desirable. As it was, the existing representative institutions merely confirmed the Administration's impotence in the face of non-cooperation by the population. Against this proposition the Administrators of the Mandate period would have argued - with considerable expert opinion on their side - that any advances towards responsible government could only have resulted in chaos and abdication from the principles of the Mandate. With regard to the second point, it would have been necessary for the Administrator and the New Zealand Government to have maintained certain powers of veto; but the experience of the nearby Kingdom of Tonga and of Samoa itself during the Trusteeship period suggests that their use would have rarely been necessary. In any case - and this point is crucial for an understanding of Samoan politics at any period - the primary motivation behind the political activities of the matai is a desire for recognition; only more recently (and in fewer cases than usually believed) has there been a desire to control the details of administration. It is also generally acknowledged that there are few more pernicious evils in government than power without responsibility; the Samoans during the Mandate period wielded immense negative power without resp onsibility. Since 1947 they have accepted increasing responsibility in the government of their country; during the same period their attitude to the problems of government has become far more 
moderate and tolerant.

It may be suggested of course that earlier introduction of constitutional reforms would have met with the same response as met Richardson's innovations. The situations were, however, quite different. The establishment of a more effective Legislative Council in the 1930 s would have met a "felt need" of the people, or at least of the class that was politically significant (see,for instance, Tumbull's comments on the demands of the Fono of 1936 quoted at p.129). Similarly, the association of leading part Europeans particularly Nelson - and leading Samoans in the Council was also desired by the Samoans. The matai desired recognition in such institutions; where Richardson's scheme failed to satisfy their needs was in the official expectation that the Fono of Faipule and the District Councils would become effective working bodies, and also in the method of appointment. What the Samoan really desired at this stage was official recognition based on traditional selection. To some extent the Fono of Faipule, after 1936, filled this role but its obvious lack of $p$ ower in many matters - parti cularly financial - frustrated the Samoan leaders. This was not so much because they wished to exercise the powers withheld from them, but rather because of their pre-eminent concern with status, their feeling that they were not being sufficiently recognised. Throughout this final chapter the differences between the European and Samoan ways of life have been stressed; and yet the earlier introduction of institutions based on Western 
political ideas has been suggested as the path of political wisdom. Other observers have suggested that a more realistic course would have been the establishment of institutions based on principles and expedients taken from past Samoan experience. The main objection to this policy is that the institutions of the past are in no way suited to the needs, not so much of the present, but certainly of the future. It has been necessary to establish an entirely new structure of central government; this, in turn, both presupposes and assists the development of a feeling of national unity.

By modelling the constitution of Western Samoa on the principles of Parliamentary government, New Zealand is not forcing upon the Territory a form of government demonstrably unsuited to the social conditions and history of the people. Undoubtedly, as the present study has shown, alien institutions will be modified by the introduction of Samoan concepts; but this is not the same thing as establishing institutions which are an artificial blend of both cultures. The process of acculturation cannot be forced. Parliamentary institutions may not be the complete answer to Samoa's constitutional problems, but all any alien power can do is to provide the institutional framework which it thinks will meet the future needs of the people; it may still be necessary for the Samoans to grow at their own pace into the clothing of a mature modern democratic state; the possibility that this maturity may adapt the form and inter-relationship of the present 
Western institutions must be left to time and to the people who participate in the political process. 


\section{BIBLIOGRAPHY}

I. UNPUBLISHED DOCIJMENTS

(a) Files of the Department of Island Territories, Wellington. 1

I.T. 1/8 Legislative Council of Western Samoa.

I.T. 1/10 Administration of Samoa - Report by Colonel Logan dated 8 July 1919.

I.T. 1/23/1 Citizens' Meeting Regarding Prime Minister's Visit, 1922.

I.T. 1/23/8 Mau Agitation.

I.T. 1/23/15 Survey of International Affairs

by A. Toynbee (Chapter re Samoa) with

commentary by C. A. Berendsen.

I.T. 1/23/20 Police V O. F. Nelson (Exhibits 3 vols.)

I.T. 1/32 Report by Colonel Tate on Administration of Samoa, 1923 .

I.T. 1/33/1 Administration - Private Correspondence Between Sir G. S. Richardson, Administrator and Sir Francis Bell, Minister of External Affairs.

I.T. 1/65 Visit of Parliamentary Representatives 1936 Goodwill Delegation.

I.T. 2/11 Confidential Political Reports

I.T. 2/15 Western Samoa - Historical Notes, re.1935 (C.G.R. McKay).

1 These files, (prior to 1943 held by the Department of External Affairs) were in February 1960 transferred to the National Archives. Although almost all of the files of the Department relating to Western Samoa were perused only those of direct relevance to the present study are included here. 
I.T. 67/12/1 Samoa - Retention of by the British.

I.T. 67/12/2 Constitution for Samoa.

I.T. $67 / 12 / 3$ Order in Council - Samoa Constitution Order and Amendments.

I.T. 67/25 Samoa Act 1921 .

I.T. $67 / 34$ Legislation - Native Regulations

Empowering Order 1924; Native Regulations 1938.

I.T. $88 / 3$ Natives - Fono of Faipule; Interim Reports of Native Affairs by Administrator.

(b) Miscellaneous

Allen, S.S. Confidential Notes on Administration, Apia, 17 January 1931 (Typescript held by Department of Island Territories).

Braisby, A.I. A Documentary Record and History of the Lauati Rebellion in Western Samoa - 1909 (Compiled from Original Native Office Documents) 3 vols. Apia, 1933. (Typescript held by Department of Island Territories.)

Davidson, J.W. The Government of Western Samoa - Survey,

Department of External Affairs, Wellington, 20 June 1947. (Cyclostyled.)

Ma'ia'a, Fanaafi. A Study of the Developing Pattern of Education and the Factors Influencing That Development in New Zealand's Pacific Dependencies, M.A. Thesis, Victoria University, 1957 (Cyclostyled copy held by Department of Island Territories.) Samoan Petition 1931, Petition of the Mau to the Governments of Great Britain, U.S.A. and Germany. (Copy held by Department of Island Territories.) 
Withefford, H. Samoa, The War and Trusteeship, War History Narrative, Department of Internal Affairs, Wellington, February 1951. (Typescript held by Department of Island Territories.)

II. OFFICIAL PUBLICATIONS

Department of External Affairs, Mandated Territory of Western Samoa - (Annual Reports of the Government of the Dominion of New Zealand on the Administration of) Parliamentary Paper A-4, Government Printer, Wellington, 1921-1941. Western Samoa 1947 - Report to the Trusteeship Council by United Nations Mission to Western Samoa. Government Printer, Wellington, 1947.

Department of Island Territories, Mandated Territory of Western Samoa - (Annual Reports on the Administration of the Mandated Territory of Western Samoa) Parliamentary Paper A-4, Government Printer, Wellington, 1945, 1946.

Western Samoa - Administered Under Trusteeship, Report for the Calendar Year. Parliamentary Paper A-4, Government Printer, Wellington, 1947 - 1959.

Western Samoa - (Report of Royal Comission Concerning the Administration of). Government Printer, Wellington, 1928.

Western Samoa - Financial and Banking Survey, Government Printer, Wellington, May 1957.

III. BOOKS

(a) With Particular Reference to Western Samoa Grattan, F.J.H. An Introduction to Samoan Custom, Samoa Printing \& Publishing Company Limited, Apia, 1948. 
Keesing, F.M. Modern Samoz - Its Government and Changing Life, George Allen \& Unwin Limited, London, 1934.

" (with Keesing, Marie M.) Elite Communication in Samoa A Study of Leadership, Stanford Univ. Press, Stanford, 1956.

Rowe, N.A. Samoa Under the Sailing Gods, Putnam, London, 1930. Smith, S.J. The Samoa (NZ) Expeditionary Force 1914-15, Ferguson \& Osborn Limited, Wellington, 1924. Stanner, W.E.H. The South Seas in Transition - A Study of Post War Rehabilitation and Reconstruction in Three British Pacific Dependencies. Australasian Publishing Company, Sydney, 1953, pp. 259-340.

Stace, V.D. Western Samoa - An Economic Survey. South Pacific Commission Technical Paper, No. 91, Nounea, June 1956.

Watson, R.M. A Short History of Samoa, Wellington, 1918.

\section{(b) General}

Apter, David E. The Gold Coast in Transition, Princeton University Press, Princeton, 1955. Davidson, J.W. The Northern Rhodesia Legislative Council, Faber \& Faber, London, 1948. Hailey, Lord. Native Administration in the British African Territories, Part IV. H.M. Stationery Office, London, 1951. " An African Survey - Revised 1956, Oxford University Press, London, 1957.

Duncan Hall, H. Mandated Dependencies and Trusteeship,

Stevens \& Sons, London, 1948.

Hodgkins, Thomas. Nationalism in Colonial Africa, Frederick Muller Limited, London, 1956. 
Jennings, Sir Ivor. The Constitution of Ceylon, Oxford

University Press, London, 1949.

Namasivayam, S. The Legislatures of Ceylon, Faber \& Faber,

London, 1951.

Wheare, Joan. The Nigerian Legislative Council, Faber \& Faber, London, 1950.

Wight, Martin. The Development of the Legislative Council 1606 - 1945, Faber \& Faber, London, 1946.

IV. ARTICLES

Boyd, Mary. Political Development in Western Samoa and Universal Suffrage in vol. 8, No. 1, March 1956 of Political Science (Victoria University College, Wellington) Davidson, J.W. Political Development in Western Samoa in vol. XXI, No. 2, June 1948 of Pacific Affairs (Institute of Pacific Relations). 